ZFCEIVED

APR 011996

\title{
OSTI
}

\section{NCAW Feed Chemistry: Effect of Starting Chemistry on Melter Offgas and Iron Redox}
P. A. Smith
J. D. Vienna
M. D. Merz

March 1995

Prepared for the U.S. Department of Energy under Contract DE-AC06-76RLO 1830

Pacific Northwest Laboratory

Operated for the U.S. Department of Energy

by Battelle Memorial Institute

\section{3.t. Battelle}




\title{
NCAW Feed Chemistry: Effect of Starting Chemistry on Melter Offgas and Iron Redox
}

\author{
P. A. Smith \\ J. D. Vienna \\ M. D. Merz
}

March 1995

Prepared for

the U.S. Department of Energy

under Contract DE-AC06-76RLO 1830

Pacific Northwest National Laboratory

Richland, Washington 99352 


\section{DISCLAIMER}

This report was prepared as an account of work sponsored by an agency of the United States Government. Neither the United States Government nor any agency thereof, nor Battelle Memorial Institute, nor any of their employees, makes any warranty, express or implied, or assumes any legal liability or responsibility for the accuracy, completeness, or, usefulness of any information, apparatus, product, or process disclosed, or represents that its use would not infringe privately owned rights. Reference herein to any specific commercial product, process, or service by trade name, trademark, manufacturer, or otherwise does not necessarily constitute or imply its endorsement, recommendation, or favoring by the United States Government or any agency thereof, or Battelle Memorial Institute. The views and opinions of authors expressed herein do not necessarily state or reflect those of the United States Government or any agency thereof.

\section{PACIFIC NORTHWEST NATIONAL LABORATORY operated by \\ BATTELLE \\ for the \\ UNITED STATES DEPARTMENT OF ENERGY \\ under Contract DE-ACO6-76RLO 1830}

Printed in the United States of America

Available to DOE and DOE contractors from the

Office of Scientific and Technical Information, P.O. Box 62, Oak Ridge, TN 37831; prices available from (615) 576-8401.

Available to the public from the National Technical Information Service, U.S. Department of Commerce, 5285 Port Royal Rd., Springfield, VA 22161 


\section{Summary}

The Pacific Northwest Laboratory (i) (PNL) Vitrification Technology Development (PVTD) program has been established to develop technology to support immobilization of selected Hanford wastes. The effort of the PVTD program is directed by the U.S. Department of Energy (DOE). This report is. part of the effort and focuses on the effect of feed preparation process chemistry on the vitrification process. The objective of the investigation was the evaluation of the effect of starting chemistry on the cold cap behavior in the vitrification of simulated neutralized current acid waste (NCAW). The investigation included the measurement of iron oxidation state, the reaction sequence during glass melting, and laboratory batch expansion measurements of the melter feed. Low temperature reduction of transition metals during cold cap reactions reduces the generation of $\mathrm{O}_{2}$ gas. The production of $\mathrm{O}_{2}$ gas by transition metals is thought to be correlated with foaming in large-scale waste vitrification. Highvolume exparisions of the batch material in the laboratory suggest poor heat transfer in the cold cap and possible reductions in large-scale meiting rate.

The term "starting chemistry" refers to the oxidants (such as nitric acid) and reductants (such as sugar and formic acid) present in the waste prior to vitrification. The starting chemistry of simulated NCAW includes untreated (unformated) waste, formic acid, nitric acid, and sugar. The formic acid, nitric acid, and sugar samples were produced by addition of these materials to the untreated waste. These (un)treated wastes were combined with frit to produce melter feed. Offgas measurements of the formic acid-containing meiter feed showed that formic acid/formate decomposed at temperatures too low for participation in a glass redox reaction. Sugar clearly pyrolized and produced $\mathrm{CO}$ and $\mathrm{H}_{2}$ at temperatures exceeding $665^{\circ} \mathrm{C}$. For the sugar-containing samples, the glass quenched. from $1200^{\circ} \mathrm{C}$ produced an $\mathrm{Fe}^{2+} / \mathrm{LFe}$ of 0.79 . The measured iron redox ratios of the glasses made from untreated waste, formic acid-, and nitric acid-containing wastes were essentially indistinguishable. The use of formic acid as a reductant did not alter the iron redox state and, therefore, was decidedly ineffective in these laboratory experiments. This result implies that formic acid will be less than $100 \%$ efficient as a reductant in large-scale vitrification. Volume expansion measurements of the batch material showed a more than sevenfold increase in volume for the sugar-containing sample below $200^{\circ} \mathrm{C}$. Volume expansions for the formic acid $\left(\sim 6.5\right.$ times original volume, $\mathrm{V}_{\mathrm{a}}$ ), nitric acid $(\sim 1.5 \mathrm{~V}$ ), and untreated $\left(\sim 2.5 \mathrm{~V}_{\partial}\right)$ samples were observed in the $720^{\circ}$ to $890^{\circ} \mathrm{C}$ range. Unfortunately, data is not available from large-scale testing that would afford a relative comparison of the volume expansion data.

(a) Pacific Northwest Laboratory is operated by Battelle Memorial Institute for the U.S. Department of Energy under Contract DE-AC06-76RLO 1830. 


\section{Acronyms}

DOE Department of Energy

DWPF Defense Waste Processing Facility

FY Fiscal Year

GC Gas Chromatograph(y)

HWVP Hanford Waste Vitrification Plant

IDMS Integrated Demonstration Melter System

IFO Index of Feed Oxidation

MS Mass Spectrometer

NCAW Neutialized Current Acid Waste

PHTD PNL HWVP Technology Development

PNL - Pacific Northwest Laboratory

PSCM Pilot Scale Ceramic Melter

PVTD PNL Vitrification Technology Development

QM Quartz Melter

SIPT Slurry Integrated Performance Test

SRL Savannah River Laboratory

TC Total Carbon

US United States of America

WHC Westinghouse Hanford Company

WO Waste Oxides

WV West Valley 


\section{Contents}

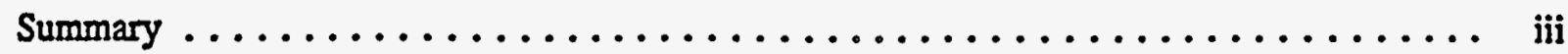

Acronyms $\ldots \ldots \ldots \ldots \ldots \ldots \ldots \ldots \ldots \ldots \ldots \ldots \ldots \ldots \ldots \ldots \ldots \ldots$

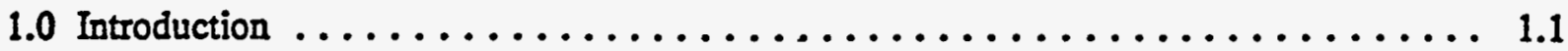

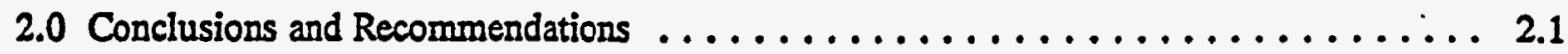

3.0 Background $\ldots \ldots \ldots \ldots \ldots \ldots \ldots \ldots \ldots \ldots \ldots \ldots \ldots \ldots \ldots \ldots \ldots \ldots \ldots$

3.1 Iron Redox and Foaming in Simulated Nuclear Waste Glass . . . . . . . . . . 3.1

3.1 .1 Laboratory Investigations of Foaming . . . . . . . . . . . . . . 3.2

3.1.2 Compositional Effects $\ldots \ldots \ldots \ldots \ldots \ldots \ldots \ldots \ldots \ldots \ldots \ldots$

3.1.3 Temperature Effects . . . . . . . . . . . . . . . . . . 3.4

4.0 Experimental Methods $\ldots \ldots \ldots \ldots \ldots \ldots \ldots \ldots \ldots \ldots \ldots \ldots \ldots \ldots \ldots$

4.1 Feed Preparation - General . . . . . . . . . . . . . . . . . . . . 4.1

4.2 Heat Treatments and Measured Data . . . . . . . . . . . . . . . . 4.1

5.0 Results and Discussion $\ldots \ldots \ldots \ldots \ldots \ldots \ldots \ldots \ldots \ldots \ldots \ldots \ldots \ldots \ldots \ldots$

5.1 Formated Melter Feed $\ldots \ldots \ldots \ldots \ldots \ldots \ldots \ldots \ldots \ldots \ldots \ldots \ldots \ldots \ldots$

5.2 Unformated NCAW Melter Feed $\ldots \ldots \ldots \ldots \ldots \ldots \ldots \ldots \ldots \ldots \ldots \ldots . \ldots \ldots$

5.3 Nitric Acid pH 4 Sample $\ldots \ldots \ldots \ldots \ldots \ldots \ldots \ldots \ldots \ldots \ldots \ldots \ldots \ldots . \ldots . \ldots$

5.4 Nitric Acid $\mathrm{pH} 44 \mathrm{X}$ Weight $\ldots \ldots \ldots \ldots \ldots \ldots \ldots \ldots \ldots \ldots \ldots \ldots \ldots$

5.5 Nitric Acid $\mathrm{pH} 6$ Melter Feed $\ldots \ldots \ldots \ldots \ldots \ldots \ldots \ldots \ldots \ldots \ldots$

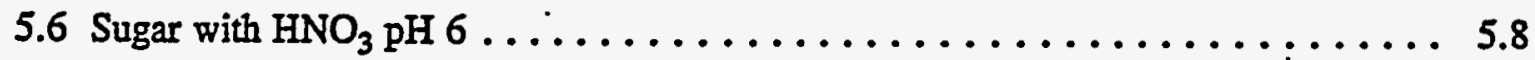

5.7 . Oxide/Carbonate Melter Feed . . . . . . . . . . . . . . . . . . 5.10 


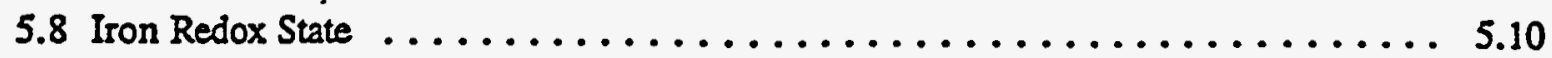

5.8.1 Evaluation of Empirical Redox Models $\ldots \ldots \ldots \ldots \ldots \ldots \ldots \ldots \ldots .11$

5.9 Volume Expansion of Melter Feeds $\ldots \ldots \ldots \ldots \ldots \ldots \ldots \ldots \ldots \ldots .11$

5.9.1 Possible Explanation for Volume Expansion Differences . . . . . . . 5.17

6.0 Comparison of Glass Redox Prepared by Quartz Melter and Pilot-Scale

Ceramic Melter Tests $\ldots \ldots \ldots \ldots \ldots \ldots \ldots \ldots \ldots \ldots \ldots \ldots \ldots . \ldots . . \ldots \ldots$

- 6.1 Comparison of $\mathrm{CO}_{2}, \mathrm{H}_{2}, \mathrm{~N}_{2}$, and $\mathrm{NO}_{x}$ Offgas for Quartz Melter and Pilot-

Scale Ceramic Melter Tests $\ldots \ldots \ldots \ldots \ldots \ldots \ldots \ldots \ldots \ldots . \ldots \ldots$

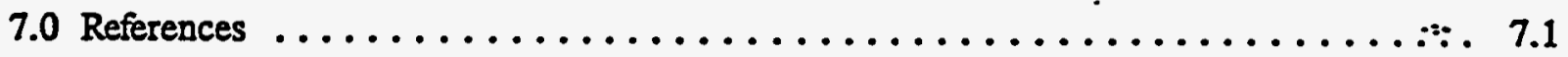

Appendix A - GC-MS Data $\ldots \ldots \ldots \ldots \ldots \ldots \ldots \ldots \ldots \ldots \ldots \ldots \ldots \ldots \ldots \ldots \ldots \ldots$

Appendix B - Some Decomposition Temperatures $\ldots \ldots \ldots \ldots \ldots \ldots \ldots \ldots \ldots$ B.1 


\section{Figures}

4.1 Schematic of Quartz Crucible Furnace . . . . . . . . . . . . . . . . 4.9

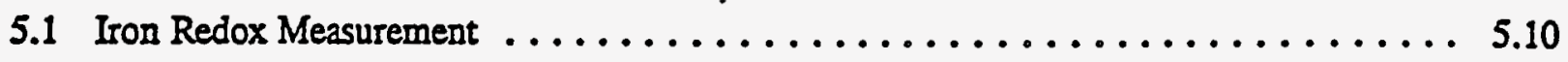

5.2A Iron Redox Ratio as a Function of the Feed Oxidation

Index for $1000^{\circ} \mathrm{C}$

5.2B Iron Redox Ratio as a Function of the Feed Oxidation Index for $1200^{\circ} \mathrm{C}$

5.3A Volume Expansion of Batch Material as a Function of Temperature

5.3B Volume Expansion of Batch Material as a Function of Temperature

6.1 Summary of Redox Comparison .

6.2 Total $\mathrm{CO}_{2}$ Offgas Dependence on Total $\mathrm{C}$ in Feed Comparing Pilot-Scale Tests to Quartz Melter Tests

6.3 Total $\mathrm{H}_{2}$ Offgas Dependence on Total $\mathrm{H}$ in Feed Comparing Pilot-Scale Tests to Quartz Melter Tests

6.4 Total $\mathrm{NO}_{x}+2 \mathrm{xN}_{2}$ Offgas Dependence on Total Nitrogen in Feed Comparing Pilot-Scale Tests to Quartz Melter Tests 


\section{Tables}

4.1 FY 1991 Neutralized Current Acid Waste Reference and Simulant Target Compositions ...................... 4.3

4.2 Recycle Simulant Composition $\ldots \ldots \ldots \ldots \ldots \ldots \ldots \ldots \ldots \ldots \ldots \ldots \ldots \ldots$

4.3 HW-39 Frit Composition $\ldots \ldots \ldots \ldots \ldots \ldots \ldots \ldots \ldots \ldots \ldots \ldots \ldots \ldots \ldots$

4.4 Sample Chemistry $\ldots \ldots \ldots \ldots \ldots \ldots \ldots \ldots \ldots \ldots \ldots \ldots \ldots \ldots \ldots \ldots . \ldots \ldots \ldots$

4.5 Composition of the Melter Feed Base in Oxides $\ldots \ldots \ldots \ldots \ldots \ldots \ldots . \ldots . \ldots$

4.6 Compound Masses and Retention Time . . . . . . . . . . . . . . 4.8

5.1. Offgas Analysis of Formated Sample . . . . . . . . . . . . . . . . 5.1

5.2. Offgas Analysis of Unformated Sample $\ldots \ldots \ldots \ldots \ldots \ldots \ldots \ldots \ldots$

5.3. Offgas Analysis of Nitric Acid $\mathrm{pH} 4$ Sample $\ldots \ldots \ldots \ldots \ldots \ldots \ldots$

5.4. Offgas Analysis of $4 \mathrm{X}$ Weight Nitric Acid $\mathrm{pH} 4 \ldots \ldots \ldots \ldots \ldots \ldots$

5.5. Offgas Analysis for Nitric Acid pH6 Sample . . . . . . . . . . . . . . 5.7

5.6. Offgas Analysis of Sugar $w / \mathrm{HNO}_{3}$ Sample $\ldots \ldots \ldots \ldots \ldots \ldots \ldots \ldots$

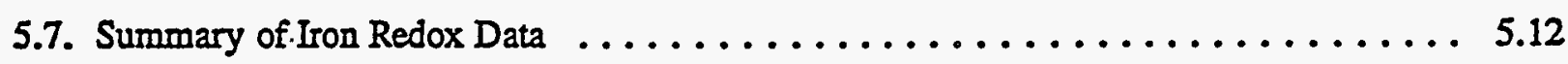

5.8. Volume Expansion Summary ......................... 5.16

6.1. Feed Compositions for Comparison $\ldots \ldots \ldots \ldots \ldots \ldots \ldots \ldots \ldots \ldots \ldots$ 


\subsection{Introduction}

The Pacific Northwest Laboratory ${ }^{(\mathfrak{(})}$ (PNL) Vitrification Technology Development (PVTD) program has been established to develop technology to support imimobilization of selected Hanford wastes. The effort of the PVTD program is directed by the U.S. Department of Energy (DOE). This report is part of the effort and focuses on the effect of starting waste chemistry on the vitrification process. The objective of the investigation was the evaluation of the effect of starting chemistry on the cold cap behavior in the vitrification of simulated neutralized current acid waste (NCAW). In addition this investigation provides an initial laboratory investigation of the cold cap and method for evaluation of alternate reductants.

This document is organized into six sections. Following the Introduction, Section 2.0 contains conclusions and recommendations. Section 3.0 reviews the background literature pertinent to this investigation. Section 4.0 details the experimental methods, and the results are shown and discussed in Section 5.0. Section 6.0 contains a comparison of glass redox data from these experiments, previous models and the Pilot Scale Ceramic Melter (PSCM) tests. References are included in Section 7.0. This report satisfies contractor milestone PVTD C94-03.02C, as described in the FY 1994 Pacific Northwest Laboratory Vitrification Technology Development Project Work Plan. ${ }^{(b)}$

(a) Pacific Northwest Laboratory is operated by Battelle Memorial Institute for the U.S. Department of Energy under Contract DE-AC06-76RLO 1830.

(b). FY 1994 Pacific Northwest Laboratory Vitrification Technology Development Project Work Plan: Volume I-HLW Vitrification. PVTD-94-001, Vol. I, Rev. 1. 


\subsection{Conclusions and Recommendations}

Experiments performed on the NCAW showed the effects of reducing agents (formic acid and sugar) and oxidant content $\left(\mathrm{NO}_{3}^{-}\right.$and $\mathrm{NO}_{2}^{-}$) on laboratory-scale vitrification under an inert atmosphere. The specific conclusions for these experiments are:

- The NCAW starting chemistries-untreated (unformated) waste, formic acid, nitric acid, and a glass produced from oxides and carbonates-showed essentially the same glass iron redox ratio for the same temperatures. For these samples, temperature strongly affected the iron redox ratio in the glass.

- The decomposition of formic acid was observed primarily between $100^{\circ}$ and $400^{\circ} \mathrm{C}$. This low decomposition temperature precludes an efficient reduction of the redox species ( $F e, ~ C r, ., n$, $\mathrm{Ce}, \mathrm{Ni})$ in the glass by formic acid/formate.

- Sugar pyrolized upon heating, and subsequently the iron was reduced significantly compared to the untreated melter feed, formic acid, and nitric acid samples. The total reducing equivalent contained in the sugar sample greatly exceeded the reducing equivalents present in the formic acid sample. The reduction in $\mathrm{Fe}^{2+} / \Sigma \mathrm{Fe}$ observed for the sugar sample resulted from the reducing agent's presence for temperatures where transition metals are reduced.

- Additions of formic acid, nitric acid, and sugar increased the total volume of gas produced

- during vitrification.

- Sugar showed more than a sevenfold increase in original volume of the batch materials, $\mathrm{V}_{0}$. The volume expansions of the formic acid $\left(\sim 6.5\right.$ times $\left.\mathrm{V}_{0}\right)$, nitric acid $\left(-1.5 \mathrm{~V}_{\circ}\right)$, untreated $\left(\sim 2.5 \mathrm{~V}_{\mathrm{o}}\right)$, and oxide/carbonate $\left(2 \mathrm{~V}_{\mathrm{o}}\right)$ samples were observed in the $720^{\circ}$ to $895^{\circ} \mathrm{C}$ temperature range. Unfortunately, the volume expansion data has not been correlated with large-scale. vitrification.

- The volume expansion did not correlate with the iron redox ratios obtained at $1000^{\circ}$ and $1200^{\circ} \mathrm{C}$

In the laboratory experiments, the addition of reductants (sugar and formic acid) caused increases in volume expansion. This volume expansion has not been related to foaming events observed in large-scale vitrification. However, the volume expansion caused by sugar and formic acid may refiect a thicker and more porous cold cap in large-scale vitrification. The role of cold-cap structure is not fully understood; hence, the use of a reductant for foam mitigation may be unnecessary.

These laboratory tests were performed in an inert atmosphere, which allowed the reaction - sequences in the melter feeds to be observed. Unfortunately, the effect of atmosphere $\left(\mathrm{pO}_{2}\right)$ on iron redox ratio, the reaction rates, and the decomposition stoichiometry could not be observed. 
The recommendations based on the work are as follows:

- Determine the requirement for a reductant in large-scale vitrification. If required, use methods similar to those described here to identify the most effective reductant for the given starting feed.

- Correlate redox ratio, offgas, and volume expansion from laboratory-scale vitrification experiments with data from large-scale experiments. 


\subsection{Background}

Historically, formic acid has been used as a reductant for simulated NCAW melter feed to reduce nitrate, nitrite and higher valent transition metals at lower temperatures. Hypothetically, reduction of these metals will release gas in the cold cap before they can be incorporated into the glass. If not reduced at low temperatures, these metals will release a large volume of gas when equilibrium is reached in the melt; this gas release is thought to cause foaming (Hrma 1990). Foaming of molten glass can cause low melting rates and process internuptions. Alternatively, over-reduced melts must be avoided to preclude the separation of elemental metals and metal sulfides. The balance of these oxidation/reduction requirements was first described for the Defense Waste Processing Facility (DWPF) (Bickford and Diemer 1986; Bickford et al. 1986). Subsequently, the electrochemical series of transition metals redox couples for DWPF Savannah River Laboratory glass frit 131 (SRL-131) was examined at $1150^{\circ} \mathrm{C}$ (Schreiber et al. 1984). Schreiber and Hockman (1987) concluded that-while redox interactions were observable between iron and other multivalent ions, the theoretical behavior of iron redox actually was observed for most conditions. Thus, the practical range for DWPF vitrification was outlined as a ferrous/ferric ratio between 0.1 and 0.5 . The remainder of this section will focus on iron redox in simulated nuclear waste glass, foaming and experimental techniques for its investigation, compositional effects on redox, and temperature.

\subsection{Iron Redox and Foaming in Simulated Nuclear Waste Glass}

Paul (1982) stoichiometrically described the reaction of ferrous and ferric iron in glass:

$$
4 \mathrm{FeO} \text { (glass) }+\mathrm{O}_{2} \text { (glass) } \rightleftharpoons 2 \mathrm{Fe}_{2} \mathrm{O}_{3} \text { (glass) }
$$

Foaming has been attributed to the release of oxygen and water vapor from simulated nuclear waste glasses (Goldman et al. 1986). A conversion of $0.1 \mathrm{wt} \%$ of iron in the +3 oxidation state to the +2 oxidation state may generate enough gas to double the glass melt volume. The use of additives, such as sugar, results in glasses with less dissolved oxygen and higher $\mathrm{Fe}^{2+} / \mathrm{Fe}^{3+}$ ratio. According to Goldman (1986), glasses formed under these conditions are less susceptible to foaming. The release of $\mathrm{O}_{2}$ occurs less readily under reducing conditions. High water pressure destabilizes the foam by altering the surface tension of thin bubble walls. For the melter feeds containing sugar, more water vapor would be produced, and a correlation between foam stability and redox may be established. However, for reducing agents such as powdered carbon, the relationship may not hold.

To produce a foam in a simulated nuclear waste glass, the evolved gases must be entrained in a continuous viscous glass (Vienna et al. in press). Reducing agents such as sugar or formic acid will be oxidized or decomposed during the vitrification process. Thus, the total quantity of evolved gas will be increased rather than decreased. Blair and Lukacs (1980) performed several crucible tests to study the effect of a variety of reductants (sugar; cornstarch; coal; Si, Al, and Fe metal; graphite; etc.). They concluded that these agents lessened the foam height in the crucible. However, close examination of 
the data showed significant scatter of the foam heights, which renders the preceding statement unsubstantiated. In addition, Goldman et al. (1986) correlated redox state, reboil pressure (a measure of dissolved oxygen in the melt), and foaming stability, and examined West Valley, Savannah River, and Hanford melter glasses. They suggested that the starting materials can solve the foaming problem. However, foaming has not been correlated in large-scale simulated nuclear waste vitrification with a side-by-side comparison of starting materials redox conditions and offgas.

\subsubsection{Laboratory Investigations of Foaming}

- The correlation of foaming between laboratory experiments and large-scale waste vitrification practice is diffcult at best. Three laboratory approaches have been described in the literature: reboil pressure (Goldman 1986), indirect observation of melt ring height (Blair and Lukacs 1980), and direct observation of the foaming (Ahn and Hrma 1986; Lucktong and Hrma 1988). The reboil pressure provides a measure of the total gas in a melt. Foaming tendency was evaluated by the reboil pressure observed when the predetermined fixed foam height was attained. Goldman's results correlated increased foaming tendency with higher reboil pressures.

The indirect observation method relies on measuring the height of the melt ring after a prescribed heat treatment. To perform these experiments, a fixed quantity of batch material is heated in a crucible of known dimensions. After the heat treatment, the height of the melt and the height of the melt ring is recorded, and an estimation of the degree of foaming is obtained. This method does not account for any profile in the advancing foam, the wetting of the crucible wall, nor a lowering of the melt ring height due to a receding foam.

The direct observation method removes the difficulties described for the indirect method. Direct observation of foaming can be made by using a transparent quartz crucible, a furnace with a window, and photographic equipment. Direct observation provides the data on foaming temperature, foam height, rate of formation, and collapse. From these direct observations, the expansion, e, can be written as a function of time (Lucktong and Hrma 1988),

$$
e=\frac{H(t)}{H(0)}-1
$$

where $\mathrm{H}$ is the total melt height. Then, the foaming can be characterized by the incubation time, $t_{j}$, the duration, $t_{d}$, the maximum height, $H_{m a x}$, and the average expansion, $e_{a}$ :

$$
e_{2}=t_{d}^{-1} \int_{t_{i}}^{t+t_{d}} e(t) d t
$$

For a linear controlled heating rate, this expression is easily interpreted in terms of temperature. 


\subsubsection{Compositional Effects}

The compositional effects on the redox of simulated nuclear waste glass can be divided into two categories: structural and starting chemistry. The balance between alkali (Schreiber et al. 1994), alkaline earth (Mysen et al. 1980), and $\mathrm{SiO}_{2}$ determines the ratio of ferrous to ferric ions and the glass structure. Recently, iron redox was considered in terms of basic-acid-amphoteric species (Iwase et al. 1994). For this study, the glass composition was not varied and will not be discussed in any further detail.

The starting chemistry of simulated nuclear waste glasses has been described in terms of formatenitrate balance for Savannah River feeds (Ramsey et al. 1991) and subsequently for Hanford feeds (Ramsey et al. 1993). From sealed crucible tests, the ratio of ferrous iron to total iron ( $\Sigma \mathrm{Fe}$ ) was related empirically for glasses at $1100^{\circ} \mathrm{C}$ by

$$
\frac{\mathrm{Fe}^{2^{+}}}{\Sigma \mathrm{Fe}}=-0.8+0.87[\mathrm{~F}-\mathrm{N}]
$$

where [F-N] denotes the molar concentration of formate minus nitrate. This relationship is valid only for $[\mathrm{F}-\mathrm{N}]>0.92$. For $[\mathrm{F}-\mathrm{N}]<0.10$, the $\mathrm{Fe}^{2+} / \mathrm{LFe}$ redox is predicted

$$
\frac{\mathrm{Fe}^{2^{+}}}{\Sigma \mathrm{Fe}}<0.10 \pm 0.05
$$

Increasing the reductant concentration resulted in a more reduced glass.

Jain (1993) investigated the effects of total carbon (TC), ${ }^{(a)}$ nitrate $\left(\mathrm{NO}_{3}\right)$, and $\mathrm{H}_{2} \mathrm{O}$ concentrations on the redox behavior of a West Valley aqueous slurry feed. The measured redox values were compared to an empirical representation of the feed chemistry and glass quenched from $1150^{\circ} \mathrm{C}$ termed the Index of Feed Oxidation (IFO). The IFO is a unitless term defined by Bowan (1990):

$$
\text { IFO }=\frac{\left(1-\phi_{w}\right)\left[\mathrm{NO}_{3}\right]}{[\mathrm{TC}]}
$$

where $\phi_{w}$ is the weight fraction of solids in the slurry. Jain observed a linear decrease in the log $\left(\mathrm{Fe}^{2+} / \mathrm{Fe}^{3+}\right)$ with increased IFO indices. Similar to Ramsey's observations, an increase in reductant content resulted in an increase in the $\mathrm{Fe}^{2+} / \mathrm{Fe}^{3+}$ ratio.

(a) Sugar was used as source. 


\subsubsection{Temperature Effects}

Glass oxidation reduction equilibrium shifts towards the reducing side with increased temperature (Paul 1982). Goldman (1983) showed the expected linear relationship for the ferrous-to-ferric ratio and $\log$ temperature for iron containing borosilicate glass compositions. Schreiber et al. (1990) showed similar behavior in the alkali borosilicate glass known as SRL 131. Presumably, this temperature dependence would be affected by the starting chemistry provided that the reductant was present in sufficient quantities to participate in a redox reaction. As part of this study, the effect of starting chemistry and temperature on iron redox equiiibrium was measured. 


\subsection{Experimental Methods}

This section describes feed preparation, the quartz crucible furnace and heat treatment, offgas analysis, volume expansion measurements, and redox determination.

\subsection{Feed Preparation-General}

The NCAW simulant (Table 4.1) was prepared according to the Slurry Integrated Performance Test (SIPT) Slurry Simulant Protocol (Smith et al. 1993). Recycle (Table 4.2) was added to the simulant. Noble metals were not included in these tests. The composition of the slurry was $28 \%$ NCAW, $3.4 \%$ recycle, and $68.6 \% \mathrm{HW}-39$ frit. This composition corresponded to a $500 \mathrm{~g}$ total oxide per liter (TO/L) slurry (42 wt\%). The frit composition is provided in Table 4.3. The frit was added to the NCAW and recycle slurry, and the suspension was boiled at $105^{\circ} \mathrm{C}$ for two hours ${ }^{(s)}$ to mimic a digestion period in the anticipated plant process. After boiling, the sample chemistry adjustments described in Table 4.4 were made. Adjustments to the melter feed chemistry were not made in an order that is reflective of plant processing. A total of 7 melter feed chemistries were examined. The untreated melter feed was treated individually with formic acid, nitric acid, and sugar. Formic acid was tested since it represents the current baseline process. Sugar was tested as an alternative reductant. Nitric acid was tested to examine the possibility of acidifying with an oxidant. The untreated sample was tested to provide a baseline for feed chemistry comparison. The formic acid sample contained $0.027 \mathrm{mmol}$ oxalate. However, the remaining samples contained $0.033 \mathrm{mmol}$ of $\mathrm{C}_{2} \mathrm{O}_{4}^{2-}$. The oxidel carbonate samples were not processed in slurry form; this sample consisted of oxides, carbonates, boric acid, and HW-39 frit. The oxide/carbonate sample did not contain any reductants. Then, the melter feed was dried at $105^{\circ} \mathrm{C}$ in air for 24 hours. After drying, the sample was crushed for 2 min in an agate dise mill to approximately -120 mesh. Samples were stored at atmospheric conditions before use in the quartz crucible furnace.

\subsection{Heat Treatments and Measured Data}

For each sample, $3 \mathrm{~g}$ of dried feed was transferred to the quartz crucible. For the nitric acid $4 \mathrm{X}$ the weight sample, $12 \mathrm{~g}$ was used. The quartz crucible was ultrasonicated to remove feed fiom the crucible sides. Then, several holes were made in the powdered feed with a wire (diameter = $0.003 \mathrm{~cm}$ ) to avoid transport of the batch monolith upward in the crucible. The composition of the base melter feed (without frit) for the 3-g samples is provided in Table 4.5.

These samples were heated in the quartz crucible furnace (see Figure 4.1) from room temperature to $1000^{\circ} \mathrm{C}, 1044^{\circ} \mathrm{C}$ or $1200^{\circ} \mathrm{C}$. The quartz crucible allowed the examination of macroscopic sample changes during processing (Kim and Hrma 1990; Ahn and Hrma 1986). Volume expansion measurements were made from recorded images.

(a) For mixing vessel description, see page 4.9 and 4.10 of P. A. Smith 1994, "HWVP NCAW Melter Feed Rheology FY. 1993 Testing and Analysis," PHTD-C93-03.02D. 
After attaining the desired temperature, the samples rere quenched in air; and the iron redox state was measured by colormetric titration of the powdered glass (Jones et al. 1981). A 4\% error has been estimated for this method for typical simulated nuclear naste glasses (Goldman and Brite 1986).

Offigas of the heated sample was analyzed by gas chromatography-mass spectrometry (GC-MS) using a Hewlett Packard model 5890 gas chromatograph (GC) and a model 5971 mass spectrometer (MS). The GC's Pora PLOT Q column was maintained at $90^{\circ} \mathrm{C}$. The inlet (and crucible) pressure was $6.1 \mathrm{psi}$, and a corresponding backpressure regulator was set at $6.1 \mathrm{psi}$ (to avoid baseline upsets). GC injections were made once a minute by a valve rotator, which allowed the gas species to be identified every $10^{\circ} \mathrm{C}$. The MS was operated in a selected ion mode. Table 4.6 lists the retention times of the analyzed species; the scanned masses appear in bold. Please note: $\mathrm{N}_{2} \mathrm{O}$ and $\mathrm{NO}_{2}$ were not observable in the mass spectrometer. 
Table 4.1. FY 1991 Neutralized Current Acid Waste (NCAW) Reference ${ }^{(1)}$ and Simulant Target Compositions

FY 1991 Reference NCAW Composition

\begin{tabular}{|c|c|c|c|}
\hline Component & $\begin{array}{c}\text { Component } \\
\text { (wt\%) }\end{array}$ & $\begin{array}{l}\text { MoI Element } \\
\text { L Feed } \\
\text { (125 gWO/L) }\end{array}$ & $\begin{array}{c}\text { Substitution } \\
\text { Deletion }\end{array}$ \\
\hline $\mathrm{Ag}_{2} \mathrm{O}$ & $1.20 \mathrm{E}-01$ & $1.29 \mathrm{E}-03$ & \\
\hline $\mathrm{Al}_{2} \mathrm{O}_{3}$ & $9.04 \mathrm{E}+00$ & 2.22E-01 & \\
\hline $\mathrm{Am}_{2} \mathrm{O}_{3}$ & $7.22 \mathrm{E}-02$ & $5.38 \mathrm{E}-07$ & DEL \\
\hline $\mathrm{As}_{2} \mathrm{O}_{3}$ & $4.25 \mathrm{E}-05$ & $3.41 \mathrm{E}-04$ & DEL \\
\hline $\mathrm{B}_{2} \mathrm{O}_{3}$ & 5.75E-03 & $2.06 \mathrm{E}-04$ & \\
\hline $\mathrm{BaO}$ & $1.76 \mathrm{E}-01$ & $1.43 \mathrm{E}-03$ & \\
\hline $\mathrm{BeO}$ & $1.01 \mathrm{E}-01$ & 5.04E-03 & SUB Mg \\
\hline $\mathrm{Br}$ & - & - & $N / A$ \\
\hline $\mathrm{CaO}$ & 7.91E-01 & $1.76 \mathrm{E}-02$ & \\
\hline CaO & $3.02 E+\infty 0$ & $2.94 \mathrm{E}-02$ & \\
\hline $\mathrm{CeO}_{2}$ & $6.05 \mathrm{E}-01$ & $4.39 \mathrm{E}-03$ & \\
\hline $\mathrm{CO}_{2} \mathrm{O}_{3}$ & - & - & \\
\hline $\mathrm{Cr}_{2} \mathrm{O}_{3}$ & $2.62 \mathrm{E}-01$ & $4.30 E-03$ & \\
\hline $\mathrm{Cs}_{2} \mathrm{O}$ & $6.05 E-01$ & 5.32E-03 & \\
\hline $\mathrm{CuO}$ & 2.45E-01 & 3.85E-03 & \\
\hline $\mathrm{Dy}_{2} \mathrm{O}_{3}$ & $1.04 \mathrm{E}-04$ & $6.98 \mathrm{E}-07$ & SUB Nd \\
\hline $\mathrm{Er}_{2} \mathrm{O}_{3}$ & $3.08 \mathrm{E}-06$ & 2.02E-08 & SUB Nd \\
\hline $\mathrm{Eu}_{2} \mathrm{O}_{3}$ & $2.02 \mathrm{E}-02^{\circ}$ & 1.42E-04 & SUB Nd \\
\hline F & $9.70 \mathrm{E}-02$ & $6.38 E-03$ & \\
\hline $\mathrm{Fe}_{2} \mathrm{O}_{3}$ & $2.82 \mathrm{E}+01$ & 4.42E-01 & \\
\hline $\mathrm{Gd}_{2} \mathrm{O}_{3}$ & $3.70 \mathrm{E}-03$ & 2.57E-05 & SUB Nd \\
\hline $\begin{array}{l}\mathrm{GeO}_{2} \\
\mathrm{HeO}\end{array}$ & $\begin{array}{c}1.57 \mathrm{E}-04 \\
-\end{array}$ & $\begin{array}{c}1.82 E-06 \\
-\end{array}$ & $N / A$ \\
\hline $\mathrm{HO}_{2} \mathrm{O}_{3}$ & $5.32 \mathrm{E}-06$ & $3.52 \mathrm{E}-08$ & SUB Nd \\
\hline$I$. & $4.50 \mathrm{E}-06$ & $4.36 E-08$ & \\
\hline $\ln _{2} \mathrm{O}_{3}$ & - & - & N/A \\
\hline $\mathrm{K}_{2} \mathrm{O}$ & $1.96 \mathrm{E}-01$ & $5.21 E-03$ & \\
\hline $\mathrm{La}_{2} \mathrm{O}_{3}$ & $6.53 \mathrm{E}-01$ & $5.01 E-03$ & \\
\hline $\mathrm{Li}_{2} \mathrm{O}$ & $1.84 \mathrm{E}-04$ & $5.92 \mathrm{E}-06$ & \\
\hline $\mathrm{MgO}$ & $2.02 E-01$ & $6.25 E-03$ & \\
\hline $\mathrm{MnO}_{2}$ & $2.14 \mathrm{E}+00$ & $3.08 \mathrm{E}-02$ & \\
\hline $\mathrm{MoO}_{3}$ & 5.59E-01 & 4.85E-03 & \\
\hline $\mathrm{Na}_{2} \mathrm{O}$ & $2.14 \mathrm{E}+01$ & 8.64E-01 & \\
\hline $\mathrm{Nb}_{2} \mathrm{O}_{3}$ & $1.01 \mathrm{E}-02$ & $1.08 \mathrm{E}-04$ & \\
\hline $\mathrm{Nd}_{2} \mathrm{O}_{3}$ & $5.78 \mathrm{E}-01$ & $4.29 \mathrm{E}-03$ & \\
\hline $\mathrm{NiO}$ & $2.30 \mathrm{E}+00$ & $3.85 \mathrm{E}-02$ & \\
\hline $\mathrm{NpO}_{2}$ & - & . - & \\
\hline $\mathrm{P}_{2} \mathrm{O}_{5}$ & 8.72E-01 & $1.53 E-02$ & \\
\hline
\end{tabular}

FY 1991 NCAW Simulant Target Composition ${ }^{(0)}$

\begin{tabular}{ccc}
\hline $\begin{array}{c}\text { Component } \\
(w t \%)\end{array}$ & & $\begin{array}{c}\text { Mol Element } \\
\text { L Feed } \\
(125 \mathrm{gWO} / \mathrm{L})\end{array}$ \\
\cline { 1 - 1 } $\begin{array}{c}1.22 \mathrm{E}-01 \\
9.25 \mathrm{E}+00\end{array}$ & & $\begin{array}{c}1.32 \mathrm{E}-03 \\
-\end{array}$ \\
- & & - \\
- & & - \\
$5.86 \mathrm{E}-03$ & & $2.10 \mathrm{E}-04$ \\
$1.79 \mathrm{E}-01$ & & $1.4 \overline{\mathrm{EE}}-03$ \\
- & -
\end{tabular}

8.06E-01 $\quad 1.80 \overline{\mathrm{E}}-02$

$3.08 \mathrm{E}+00 \quad 3.00 \mathrm{E}-02$

$6.56 \mathrm{E}-01 \quad 4.77 \mathrm{E}-03$

2.67E-01 4.39E-03

6.12E-01 5.43E-03

2.50E-01 3.93E-03

$\begin{array}{cc}\overline{-} & \overline{-} \\ \overline{-} & \overline{-} \\ 9.90 \mathrm{E}-02 & 6.52 \mathrm{E}-03 \\ 2.88 \mathrm{E}+01 & 4.51 \mathrm{E}-01\end{array}$

$1.56 \mathrm{E}-04 \quad 1.86 \overline{\mathrm{E}}-06$

$-$

- -

4.60E-06 4.53E-08

2.00E-01 5.32E-03

6.67E-01 5.12E-03

7.23E-05 6.05E-06

3.72E-01 1.15E-02

$2.19 \mathrm{E}+00 \quad 3.15 \mathrm{E}-02$

5.70E-01 4.95E-03

$2.19 \mathrm{E}+01 \quad 8.82 \mathrm{E}-01$

$1.03 \mathrm{E}-02 \quad 1.10 \mathrm{E}-04$

$3.56 \mathrm{E}+00 \quad 2.64 \mathrm{E}-02$

2.35E +00 3.93E-02

8.87E-01 $1.5 \overline{\mathrm{E}}-02$ 
Table 4.1. (contd)

FY 1991 Reference NCAW Composition

\begin{tabular}{|c|c|c|c|c|c|}
\hline \multicolumn{4}{|c|}{ FY 1991 Reference NCAW Composition } & \multicolumn{2}{|c|}{ larget Composmon } \\
\hline Component & $\begin{array}{l}\text { Component } \\
\text { (wt\%) }\end{array}$ & $\begin{array}{l}\text { MoI Element } \\
\text { L Feed } \\
(125 \mathrm{gWO} / \mathrm{L})\end{array}$ & $\begin{array}{l}\text { Substitution } \\
\text { Deletion }\end{array}$ & $\begin{array}{l}\text { Component } \\
\text { (wt\%) }\end{array}$ & $\begin{array}{l}\text { Mol Element } \\
\text { L Feed } \\
(125 \mathrm{gWO} / \mathrm{L})\end{array}$ \\
\hline $\begin{array}{l}\mathrm{PbO}_{2} \\
\mathrm{PdO} \\
\mathrm{Pm}_{2} \mathrm{O}_{3} \\
\mathrm{Pr}_{2} \mathrm{O}_{3} \\
\mathrm{PuO}_{2} \\
\mathrm{Rb}_{2} \mathrm{O}_{3} \\
\mathrm{Re}_{2} \mathrm{O}_{7} \\
\mathrm{Rh}_{2} \mathrm{O}_{3} \\
\mathrm{Ru}_{2} \mathrm{O}_{3} \\
\mathrm{SO}_{3} \\
\mathrm{Sb}_{2} \mathrm{O}_{3} \\
\mathrm{SeO}_{2} \\
\mathrm{SiO}_{2} \\
\mathrm{Sm}_{2} \mathrm{O}_{3} \\
\mathrm{SnO} \\
\mathrm{SrO}^{\mathrm{Ta}_{2} \mathrm{O}_{5}} \\
\mathrm{~Tb}_{2} \mathrm{O}_{3} \\
\mathrm{TcO}_{2} \mathrm{O}_{7} \\
\mathrm{TeO}_{2} \\
\mathrm{ThO}_{2} \\
\mathrm{TiO}_{2} \\
\mathrm{Tm}_{2} \mathrm{O}_{3} \\
\mathrm{U}_{3} \mathrm{O}_{8} \\
\mathrm{Y}_{2} \mathrm{O}_{3} \\
\mathrm{ZnO}^{\mathrm{ZrO}_{2}}\end{array}$ & $\begin{array}{c}7.00 \mathrm{E}-01 \\
1.20 \mathrm{E}-01 \\
4.60 \mathrm{E}-02 \\
1.53 \mathrm{E}-01 \\
6.00 \mathrm{E}-02 \\
5.75 \mathrm{E}-02 \\
- \\
1.04 \mathrm{E}-01 \\
3.80 \mathrm{E}-01 \\
6.55 \mathrm{E}-01 \\
5.88 \mathrm{E}-03 \\
1.59 \mathrm{E}-02 \\
4.03 \mathrm{E}+00 \\
7.50 \mathrm{E}-02 \\
1.08 \mathrm{E}-02 \\
1.19 \mathrm{E}-01 \\
3.33 \mathrm{E}-03 \\
2.26 \mathrm{E}-04 \\
1.52 \mathrm{E}-01 \\
1.07 \mathrm{E}-01 \\
-\overline{1} \\
6.52 \mathrm{E}-01 \\
1.68 \mathrm{E}-10 \\
4.74 \mathrm{E}+00 \\
7.99 \mathrm{E}-02 \\
3.34 \mathrm{E}-01 \\
1.51 \mathrm{E}+01\end{array}$ & $\begin{array}{c}3.66 \mathrm{E}-03 \\
1.23 \mathrm{E}-03 \\
3.32 \mathrm{E}-04 \\
1.16 \mathrm{E}-03 \\
2.77 \mathrm{E}-04 \\
6.56 \mathrm{E}-04 \\
- \\
1.02 \mathrm{E}-03 \\
3.77 \mathrm{E}-03 \\
1.02 \mathrm{E}-02 \\
5.00 \mathrm{E}-05 \\
1.78 \mathrm{E}-04 \\
8.38 \mathrm{E}-02 \\
5.42 \mathrm{E}-04 \\
9.78 \mathrm{E}-05 \\
1.43 \mathrm{E}-03 \\
1.88 \mathrm{E}-05 \\
1.54 \mathrm{E}-06 \\
1.23 \mathrm{E}-03 \\
7.77 \mathrm{E}-04 \\
- \\
1.02 \mathrm{E}-02 \\
1.09 \mathrm{E}-12 \\
2.11 \mathrm{E}-02 \\
8.85 \mathrm{E}-04 \\
5.13 \mathrm{E}-03 \\
1.53 \mathrm{E}-01\end{array}$ & $\begin{array}{l}\text { SUB ZT } \\
\text { SUB Nd } \\
\text { SUB Nd }\end{array}$ & $\begin{array}{c}7.15 \mathrm{E}-01 \\
1.23 \mathrm{E}-01 \\
- \\
1.56 \mathrm{E}-01 \\
- \\
5.87 \mathrm{E}-02 \\
- \\
1.06 \mathrm{E}-01 \\
3.87 \mathrm{E}-01 \\
6.69 \mathrm{E}-01 \\
5.95 \mathrm{E}-03 \\
1.61 \mathrm{E}-02 \\
4.11 \mathrm{E}+00 \\
7.72 \mathrm{E}-02 \\
1.08 \mathrm{E}-02 \\
1.21 \mathrm{E}-01 \\
3.39 \mathrm{E}-03 \\
- \\
- \\
1.01 \overline{\mathrm{E}}-01 \\
- \\
6.66 \mathrm{E}-01 \\
- \\
- \\
8.17 \mathrm{E}-02 \\
3.41 \mathrm{E}-01 \\
1.54 \mathrm{E}+01\end{array}$ & $\begin{array}{c}3.74 \mathrm{E}-03 \\
1.26 \mathrm{E}-03 \\
\overline{-} \\
1.18 \mathrm{E}-03 \\
\overline{6} \\
6.70 \mathrm{E}-04 \\
- \\
1.04 \mathrm{E}-03 \\
3.85 \mathrm{E}-03 \\
1.04 \mathrm{E}-02 \\
5.11 \mathrm{E}-05 \\
1.82 \mathrm{E}-04 \\
8.56 \mathrm{E}-02 \\
5.54 \mathrm{E}-04 \\
9.99 \mathrm{E}-05 \\
1.46 \mathrm{E}-03 \\
1.92 \mathrm{E}-05 \\
- \\
- \\
7.94 \mathrm{E}-04 \\
- \\
1.04 \mathrm{E}-02 \\
- \\
- \\
9.04 \mathrm{E}-04 \\
5.24 \mathrm{E}-03 \\
1.56 \mathrm{E}-01\end{array}$ \\
\hline Sum & $1.00 \mathrm{E}+02$ & $2.02 E+00$ & & $1.00 \mathrm{E}+02$ & $2.06 E+00$ \\
\hline
\end{tabular}

FY 1991 NCAW Simulant

Target Composition ${ }^{(b)}$

(a) Smith, R. A. 1991. "Revision of Pretreated Neutralized Current Acid Waste Composition for FY 1991 Pilot Testing-Errata Correction." Letter to J. M. Creer \$915051.

(b) Actual test slurry composition with substitutions made. 
Table 4.2. Recycle Simulant Composition

Reference and Target Oxides in Recyclo Simulant

\begin{tabular}{l} 
Oxide \\
\hline \multicolumn{1}{c}{ OxO } \\
$\mathrm{MnO}_{2}$ \\
$\mathrm{Ne}_{2} \mathrm{O}^{2}$ \\
$\mathrm{P}_{2} \mathrm{O}_{5}$ \\
$\mathrm{NO}_{3}^{-}$ \\
$\mathrm{Cl}^{-}$ \\
$\mathrm{TOC}^{\text {Diatomaccous Earth }}$ \\
$\mathrm{Zcolito}$ (IE-96)
\end{tabular}

Reference ${ }^{(b)} g$
Recyclo
Oxide/g Oxido

in SRAT

Slurry

0.004

0.0012

0.05

0.004

0.08

0.00008

0.0027

0.04

0.02

0.1192
Target Value $(s)$
g Recyclo
Oxide/L of
Recyclo
Simulant

2.01

0.60

25.17

2.01

40.27

0.04

1.36

20.15

10.07

60
Sources of Recycle Simulant for NCAW Slumy Simulant ${ }^{(2)}$

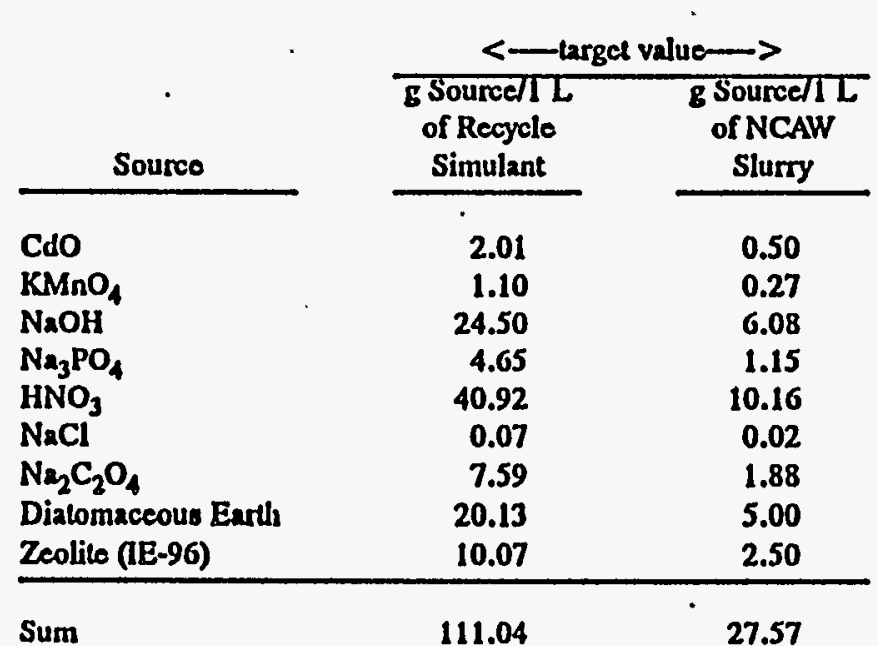

(a) Approximately 0.19 mol of HCOOH/L was added to recycle simulant before it was added to the NCAW simulant. Ono liter of NCAW slurry is about $125 \mathrm{gWO} / \mathrm{L}$ of NCAW slurry. The approximato amount of recyclo simulant necessary for addition to $1 \mathrm{~L}$ of NCAW . bimulant is $250 \mathrm{~mL}$ of recyclo simulant about $60 \mathrm{~g}$ recyclo oxide/ $\mathrm{L}$ of recycle simulant.

Nole: The recycle slurny was added on the basis of the gram wasto oxides present in the vessel at the end of digestion. The amount of gram waste oxides was determined by subtracting tho waste oxides contained in slumy samples (which were removed during formic acid addition and digestion) from the initial gram waste oxides (initial gram waste oxides $=1.5 \mathrm{~L}$ of slurry $\bullet 125 \mathrm{gWO} / \mathrm{L}$ of slurry $=$ $187.5 \mathrm{~g}$ WO).

(b) Smith, R. A. 1991. "Revision of Pretrealed Neutralized Current Acid Wasto Composition for FY 1991 Pilot Testing-Errala Correction." Letter to J. M. Creer \$915051.

(c) The target concentration for the recycle slurry is $60 \mathrm{~g}$ oxide/L of recycle. To convert from column 2 to 3: g recycle oxide/sum of nonvolatiles $\bullet 60 \mathrm{~g}$ tolal recycle oxide/L of recycle. 
Table 4.3. HW-39 Frit Composition

$$
\mathrm{Wt} \%_{70}^{\mathrm{SiO}_{2}} \frac{\mathrm{B}_{2} \mathrm{O}_{3}}{14} \frac{\mathrm{Na}_{2} \mathrm{O}}{9} \frac{\mathrm{Li}_{2} \mathrm{O}}{5} \frac{\mathrm{CaO}}{1} \frac{\mathrm{MgO}}{1}
$$

Table 4.4. Sample Chemistry. These sample chemistries are the result of the additions described in

\begin{tabular}{|c|c|c|c|c|c|c|c|}
\hline \multirow[b]{2}{*}{ Sample Name } & \multicolumn{6}{|c|}{ Species (mmol).per 3-g Sample } & \multirow[b]{2}{*}{ Comments } \\
\hline & $\mathrm{NO}_{3}^{-}$ & $\mathrm{NO}_{2}^{-}$ & $\mathrm{CO}_{3}^{-}$ & $\mathrm{C}_{2} \mathrm{O}_{4}^{2-}$ & $\mathrm{HCOO}^{-}$ & $\mathrm{C}_{12} \mathrm{H}_{22} \mathrm{O}_{1 \mathrm{i}}$ & \\
\hline Unformated & 1.74 & 2.71 & 0.77 & 0.033 & & & Nothing adied \\
\hline $\begin{array}{l}\text { Nitric acid } \\
\text { pH4 }\end{array}$ & 20.86 & 7.67 & & 0.033 & & & Titrated $w / \mathrm{HNO}_{3}$ \\
\hline $\begin{array}{l}\text { Nitric acid } \\
\text { pH6 }\end{array}$ & 3.26 & 3.51 & & 0.033 & - & & Titrated $w / \mathrm{HNO}_{3}$ \\
\hline $\begin{array}{l}\text { Sugar w/ } \\
\mathrm{HNO}_{3}\end{array}$ & .20 .86 & 7.67 & & 0.033 & & 6.67 & $\begin{array}{l}\text { Titrated } \mathrm{w} / \mathrm{HNO}_{3} \text {, } \\
\text { added sucrose }\end{array}$ \\
\hline Sugar 1M & 1.74 & 2.71 & 0.77 & 0.033 & & 3.7 & Added sucrose \\
\hline $\begin{array}{l}\text { Formic acid } \\
\text { (formated) }\end{array}$ & 2.19 & 0.05 & - & 0.027 & 4.2 & & $\begin{array}{l}\text { Added the formic } \\
\text { acid to boiling } \\
\text { NCAW simulant }\end{array}$ \\
\hline $\begin{array}{l}\text { Oxide/ } \\
\text { Carbonate }\end{array}$ & & & 12.7 & & & & $\begin{array}{l}\text { Made from oxides, } \\
\text { carbonates, } \mathrm{H}_{3} \mathrm{BO}_{3} \text {, } \\
\text { and frit; mixed dry; } \\
\text { slurry was not } \\
\text { utilized }\end{array}$ \\
\hline
\end{tabular}
the comment column. No adjustments were made after the titrations or additions. 
Table 4.5. Composition of the Melter.Feed Base in Oxides (without frit)

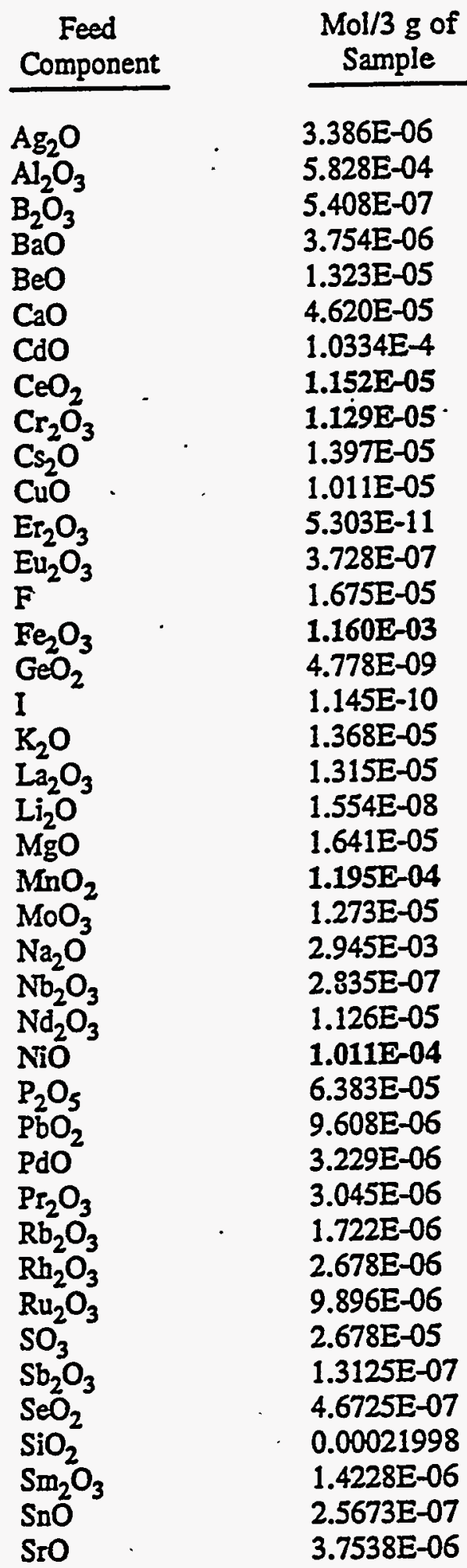


Table 4.5. (contd)

\begin{tabular}{|c|c|}
\hline $\begin{array}{c}\text { Feed } \\
\text { Component }\end{array}$ & $\begin{array}{c}\mathrm{Mol} / 3 \mathrm{~g} \text { of } \\
\text { Sample }\end{array}$ \\
\hline $\begin{array}{l}\mathrm{Ta}_{2} \mathrm{O}_{5} \\
\mathrm{TeO}_{2} \\
\mathrm{TiO}_{2} \\
\mathrm{Y}_{2} \mathrm{O}_{3} \\
\mathrm{ZnO} \mathrm{ZrO}_{2}\end{array}$ & $\begin{array}{l}4.935 E-08 \\
2.0396 E-06 \\
2.6775 E-05 \\
2.3231 E-06 \\
1.3466 E-05 \\
0.00040163\end{array}$ \\
\hline \multicolumn{2}{|c|}{ Anions for NCAW Feed Simulant } \\
\hline $\begin{array}{l}\mathrm{CL}^{-} \\
\mathrm{OH}^{-} \\
\mathrm{SO}_{4}^{-} \\
\mathrm{PO}_{4}^{-} \\
\mathrm{CO}_{3}^{-} \\
\mathrm{F}^{-} \\
\mathrm{TOC}\end{array}$ & $\begin{array}{c}2.9539 \mathrm{E}-05 \\
0 \\
2.6775 \mathrm{E}-05 \\
2.7038 \mathrm{E}-06 \\
0.00032813 \\
1.6748 \mathrm{E}-05 \\
2.26488 \mathrm{E}-04 \\
1.1445 \mathrm{E}-10\end{array}$ \\
\hline
\end{tabular}

Table 4.6. Compound Masses and Retention Time

\begin{tabular}{|c|c|c|c|}
\hline Compound & Formula & Atomic Mass & $\begin{array}{l}\text { Retention Time } \\
\text { (min) }\end{array}$ \\
\hline Hydrogen & $\mathrm{H}_{2}$ & $2^{(n)}$ & 8.40 \\
\hline Oxygen & $\mathrm{O}_{2}$ & 3216 & 8.51 \\
\hline Carbon monoxide & CÓ & 28121629 & 8.85 \\
\hline Carbon dioxide & $\mathrm{CO}_{2}$ & $4428 \quad 1622 \quad 45$ & 8.88 \\
\hline Nitric oxide & No & $3014 \quad 1516$ & 8.53 \\
\hline Sulfur dioxide & $\mathrm{SO}_{2}$ & $64 \quad 48 \quad 32 \quad 16 \quad 66$ & 12.95 \\
\hline Nitrogen . & $\mathrm{N}_{2}$ & 2814 & 8.50 \\
\hline Helium & $\mathrm{He}$ & 4 & 8.40 \\
\hline
\end{tabular}

(a) Masses listed in bold were measured by the mass spectrometer. 


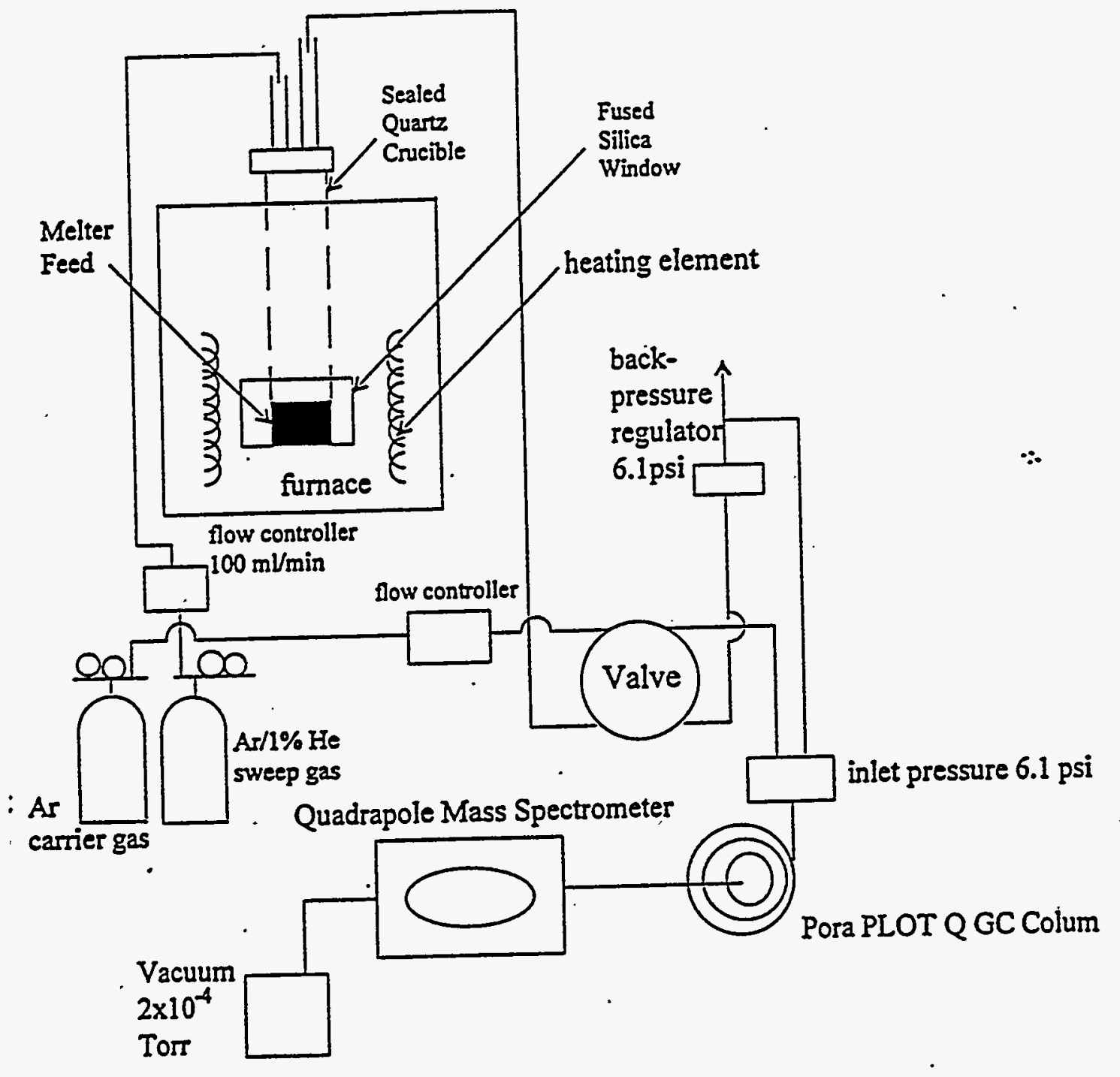

Figure 4.1. Schematic of Quartz Crucible Furnace

$\because$ 


\subsection{Results and Discussion}

\subsection{Formated Melter Feed}

The formated NCAW meiter feed sample offgas analysis is shown in Table. 5.1. The decomposi- tion of formic acid was readily observed and described in Cecille and Kelm (1986):

$$
\mathrm{HCOOH} \rightarrow \mathrm{H}_{2}+\mathrm{CO}_{2} \text {. }
$$

The starting sample contained $4.2 \mathrm{mmiol}$ of $\mathrm{HCOOH}$. Between $117^{\circ} \mathrm{C}$ and $357^{\circ} \mathrm{C}, 1.4 \mathrm{mmol}$ of $\mathrm{H}_{2}$ were detected. The remaining $2.8 \mathrm{mmol}$ of $\mathrm{H}_{2}$ expected may be dissolved in the glass. Alternatively, hydrogen can enter the structure as $\mathrm{Si}-\mathrm{OH}$. The bulk $(18.3 \mathrm{mmol})$ of the $\mathrm{CO}_{2}$ was detected between $111^{\circ} \mathrm{C}$ and $681^{\circ} \mathrm{C}$, with $15.3 \mathrm{mmol}$ detected in the range of $111^{\circ} \mathrm{C}$ to $491^{\circ} \mathrm{C}$. The measured $\mathrm{CO}_{2}$ exceeded the quantity, which can be attributed to formic acid decomposition.

Table 5.1. Offgas Analysis of Formated Sample

\begin{tabular}{|c|c|c|c|c|c|c|}
\hline Sample & Gas & $\begin{array}{l}\text { Temperature } \\
\text { Range }\left({ }^{\circ} \mathrm{C}\right)\end{array}$ & $\begin{array}{l}\text { Amount } \\
\text { (mmol) }\end{array}$ & $\begin{array}{l}\text { Possible } \\
\text { Reactions }\end{array}$ & $\begin{array}{l}\text { Starting } \\
\text { Chemistry }\end{array}$ & $\begin{array}{l}\text { Amount } \\
\text { (mmol) }\end{array}$ \\
\hline \multirow[t]{6}{*}{ Formic acid } & $\mathrm{H}_{2}$ & $160-440$ & 1.4 & 5.1 & $\begin{array}{l}\mathrm{NO}_{3}^{-} \\
\mathrm{NO}_{2}^{-}\end{array}$ & $\begin{array}{l}2.19 \\
0.05\end{array}$ \\
\hline & $\mathrm{O}_{2}$ & $\begin{array}{l}448-708 \\
718-838\end{array}$ & $\begin{array}{l}0.215 \\
0.048\end{array}$ & $\begin{array}{l}5.3,5.4 \\
5.5,5.6\end{array}$ & $\begin{array}{l}\mathrm{HCOO}- \\
\mathrm{C}_{2} \mathrm{O}_{4}\end{array}$ & $\begin{array}{l}4.2 \\
0.027\end{array}$ \\
\hline & $\mathrm{CO}_{2}$ & $\begin{array}{l}111-401 \\
111-491 \\
501-681 \\
691-1200 \\
822-1200\end{array}$ & $\begin{array}{l}13.6 \\
15.3 \\
3.00 \\
0.176 \\
0.016\end{array}$ & $5.1,5.12$ & - & $::$ \\
\hline & $\mathrm{CO}$ & $\begin{array}{l}228-328 \\
338-538\end{array}$ & $\begin{array}{l}0.028 \\
0.051\end{array}$ & 5.2 & & \\
\hline & NO & $\begin{array}{l}237-358 \\
488-708 \\
718-878\end{array}$ & $\begin{array}{l}2.74 \\
1.90 \\
0.36\end{array}$ & 5.4 & . & . \\
\hline & $\mathrm{N}_{2}$ & $148-168$ & 0.252 & 5.5 & & \\
\hline
\end{tabular}


A small amount $(0.08 \mathrm{mmol})$ of $\mathrm{CO}$ was detected, which may be described as a side reaction:

$$
\mathrm{HCOOH} \rightarrow \mathrm{H}_{2} \mathrm{O}+\mathrm{CO} \text {. }
$$

An easy description of the nitrate/nitrite thermal decomposition can be made by assuming the following (Ryan 1994):

$$
\mathrm{NaNO}_{3}-\mathrm{NaNO}_{2}+\frac{1}{2} \mathrm{O}_{2}
$$

Then, the nitrite decomposition gases, NO and $\mathrm{N}_{2}$ can be described by

$$
2 \mathrm{NaNO}_{2} \rightarrow \mathrm{Na}_{2} \mathrm{O}+2 \mathrm{NO}+\frac{1}{2} \mathrm{O}_{2}
$$

and

$$
2 \mathrm{NaNO}_{2} \rightarrow \mathrm{Na}_{2} \mathrm{O}+\mathrm{N}_{2}+\frac{3}{2} \mathrm{O}_{2} \text {. }
$$

Examination of the formated sample's offgas showed significant NO production at $310^{\circ} \mathrm{C}$ and $640^{\circ} \mathrm{C}$, and $\mathrm{N}_{2}$ production between $148^{\circ} \mathrm{C}$ and $168^{\circ} \mathrm{C}$. Presumably, for the formated NCAW sample, $2.19 \mathrm{mmol}$ of nitrate was reduced to nitrite. The gas analysis showed that $0.25 \mathrm{mmol}$ of $\mathrm{N}_{2}$ and 5.0 mmol of NO were produced. These reactions [(5.4) and (5.5)] require $5.5 \mathrm{mmol}$ of $\mathrm{NO}_{2} ;$; however, $2.24 \mathrm{mmol}$ were present assuming reaction (5.3). An analytical error may have resulted in the excess No detected.

Since formic acid was added to reduce the transition metals in the glass melt and thus, decrease the quantity of $\mathrm{O}_{2}$ evolved, the measured oxygen can be examined in light of the following general redox reaction (Schreiber et al. 1984):

$$
4 \mathrm{M} \underset{(\text { melt })}{\mathrm{n+}}+2 \mathrm{mO} \underset{\text { (melt) }}{2-}+4 \mathrm{M} \underset{(\text { melt })}{(\mathrm{n}-\mathrm{m})+}+\mathrm{mO}_{2} \text { (gas) }
$$

where $M$ represents the multivalent element, $n$ the charge on the oxidized ion, and $m$ the number of electrons transferred in the reduction. The specific redox reactions are: 


$$
\begin{aligned}
& 4 \mathrm{Mn} \underset{(\text { melt })}{3+}+2 \mathrm{O}_{(\text {melt })}^{2-}-4 \mathrm{Mn} \cdot \underset{(\text { melt })}{2+}+\mathrm{O}_{2} \text { (gas) } \\
& 4 \mathrm{Fe} \underset{(\text { melt })}{3+}+2 \mathrm{O} \underset{(\text { melt })}{2-}-4 \mathrm{Fe} \underset{(\text { melt })}{2+}+\mathrm{O}_{2} \text { (gas) } \\
& 4 \mathrm{Ce} \underset{\text { (melt) }}{4+}+2 \mathrm{O} \underset{\text { (melt) }}{2-}-4 \mathrm{Ce} \underset{\text { (melt) }}{3+}+\mathrm{O}_{2} \text { (gas) } \\
& 4 \mathrm{Ni} \underset{(\text { melt })}{3+}+20 \underset{(\text { melt })}{2-}-4 \mathrm{Ni} \underset{(\text { meit })}{2+}+\mathrm{O}_{2} \text { (gas) }
\end{aligned}
$$

and

$$
4 \mathrm{Cr} \underset{\text { (melt) }}{6+}+6 \mathrm{O} \underset{\text { (melt) }}{2-}-4 \mathrm{Cr}^{3^{+}}+3 \mathrm{O}_{2} \text { (gas) }
$$

It is clear that the Mn present is capable of producing as much $(0.27 \mathrm{mmol})$ oxygen as was detected (Table 5.1). Only a minor amount $(0.05 \mathrm{mmol})$ of $\mathrm{O}_{2}$ was detected near the temperature range in which redox reactions take place. The significant portion $(0.22 \mathrm{mmol})$ of $\mathrm{O}_{2}$ was detected between $448^{\circ} \mathrm{C}$ and $708^{\circ} \mathrm{C}$ This temperature region corresponds to the nitrate/nitrite decomposition reactions. However, an oxygen balance was not made because the oxygen can enter the glass network. The detected oxygen was much less than the anticipated $\mathrm{O}_{2}$ amounts from the nitratelnitrite decomposition. In addition, the solubility of $\mathrm{O}_{2}$ in the glass melt under these experimental conditions is not known.

\subsection{Unformated NCAW Melter Feed}

The unformated NCAW sample gas analysis is described in Table 5.2. The decomposition of carbonates in this feed was observed to be

$$
\mathrm{M}\left(\mathrm{CO}_{3}\right)_{\mathrm{n}} \rightarrow \mathrm{M}_{2-\mathrm{n}} \mathrm{O}+\mathrm{nCO}_{2}
$$


Table 5.2. Offgas Analysis of Unformated Sample

\begin{tabular}{|c|c|c|c|c|c|c|}
\hline \multirow[b]{2}{*}{ Sample } & \multirow[b]{2}{*}{ Gas } & \multirow[b]{2}{*}{$\begin{array}{l}\text { Temperature } \\
\text { Range }\left({ }^{\circ} \mathrm{C}\right)\end{array}$} & \multirow[b]{2}{*}{$\begin{array}{l}\text { Amount } \\
\text { (mmol) }\end{array}$} & \multirow[b]{2}{*}{$\begin{array}{l}\text { Possible } \\
\text { Reactions }\end{array}$} & \multicolumn{2}{|c|}{ Starting Chemistry } \\
\hline & & & & & Specie & $\begin{array}{c}\text { Amount } \\
(\mathrm{mmol})\end{array}$ \\
\hline \multirow[t]{6}{*}{ Unformated } & $\mathrm{H}_{2}$ & none & & & $\begin{array}{l}\mathrm{NO}_{3}^{-} \\
\mathrm{NO}_{2}^{-}\end{array}$ & $\begin{array}{l}1.74 \\
2.71\end{array}$ \\
\hline & $\mathrm{O}_{2}$ & $\begin{array}{l}538-808 \\
818-908\end{array}$ & $\begin{array}{l}0.314 \\
0.011\end{array}$ & $5.3-5.6$ & $\begin{array}{l}\mathrm{CO}_{3}^{2-} \\
\mathrm{C}_{2} \mathrm{O}_{4}^{2-}\end{array}$ & $\begin{array}{l}0.77 \\
0.033\end{array}$ \\
\hline & $\mathrm{CO}_{2}$ & $\begin{array}{l}161-191 \\
211-451 \\
461-761\end{array}$ & $\begin{array}{l}0.74 \\
0.57 \\
5.93\end{array}$ & $5.12,5.13$ & & $\cdots$ \\
\hline & $\mathrm{CO}$ & none & & & & \\
\hline & No & $\begin{array}{l}197-368 \\
377-588 \\
598-888\end{array}$ & $\begin{array}{l}0.912 \\
0.032 \\
0.922\end{array}$ & 5.4 & & \\
\hline & $\mathrm{N}_{2}$ & $125-1200$ & trace & 5.5 & & \\
\hline
\end{tabular}

The unformated batch originally contained $0.77 \mathrm{mmol}$ of $\mathrm{CO}_{3}^{2-}$. Experimentally, $7.24 \mathrm{mmol}$ of $\mathrm{CO}_{2}$ were observed. However, $0.033 \mathrm{mmol}$ of oxalate was present. The oxidation of sodium oxalate may be written as:

$$
\mathrm{Na}_{2} \mathrm{C}_{2} \mathrm{O}_{4}+\frac{1}{2} \mathrm{O}_{2} \rightarrow \mathrm{Na}_{2} \mathrm{O}+2 \mathrm{CO}_{2}
$$

Thus, 0.033 mmol of oxalate in the unformated sample may produce $0.066 \mathrm{mmol}$ of $\mathrm{CO}_{2}$. The total possible $\mathrm{CO}_{2}$ for the unformated sample from the oxalate and $\mathrm{CO}_{3}^{2-}$ is $0.836 \mathrm{mmol}$. The remainder of the $\mathrm{CO}_{2}$ may be attributed to adsorbed $\mathrm{CO}_{2}$ or $\mathrm{CO}_{2}$ produced by the sealant.

Using the same approach as the formated sample for the nitrate/nitrite reactions (5.3-5.5), the $1.74 \mathrm{mmol}$ of nitrate was decomposed to $1.74 \mathrm{mmol}$ of nitrite. Subsequently, $4.45 \mathrm{mmol}$ of nitrite may form $4.45 \mathrm{mmol}$ of NO, while only $1.87 \mathrm{mmol}$ of $\mathrm{NO}$ were detected. Only a trace of $\mathrm{N}_{2}$ was detected and thus, the reaction (5.5) for $\mathrm{N}_{2}$ production is essentially insiguificant. An analytical error in the GC-MS or the presence of water in the furnace-gas analyzer system may have contributed to the difficulty in the nitrogen mass balance. 
Again, using the same methodology for the $\mathrm{O}_{2}$ balance, the $\mathrm{O}_{2}$ produced in the nitrate/nitrite decomposition could not be adequately accounted for in the mass balance. The unformated sample produced $0.33 \mathrm{mmol}$ of $\mathrm{O}_{2}$. The bulk of the $\mathrm{O}_{2}(0.314 \mathrm{mmol})$ was produced in the same temperature region as the nitrate/nitrite decompositions. Similar to the formated sample, the $\mathrm{O}_{2}$ was detected at temperatures less than expected for transition metal redox reactions, and in appreciably less quantities. Therefore, this oxygen is not likely the product of atransition metal redox reaction.

\subsection{Nitric Acid pH 4 Sample}

The gas analysis of the nitric acid pH 4 sample is described in Table 5.3. The decomposition of carbonate and oxalate was observed in two primary temperature ranges: $149^{\circ} \mathrm{C}$ to $549^{\circ} \mathrm{C}$ and $559^{\circ} \mathrm{C}$ to $819^{\circ} \mathrm{C}$. Absorbed $\mathrm{CO}_{2}$ imparts some difficulty to the stoichiometric analysis. Assuming the $0.033 \mathrm{mmol}$ of $\mathrm{C}_{2} \mathrm{O}_{4}^{2-}$ would produce $0.066 \mathrm{mmol}$. Experimentally, $16.04 \mathrm{mmol}$ of $\mathrm{CO}_{2}$ were observed; the discrepancy was attributed to absorbed $\mathrm{CO}_{2}$. In addition, a side reaction occuirred that produced $1.1 \mathrm{mmol}$ of $\mathrm{CO}$.

Assuming all the nitrate was converted to nitrite, $28.53 \mathrm{mmol}$ of $\mathrm{NO}_{2}^{-}$was available for decom: position to $\mathrm{NO}, \mathrm{N}_{2}$, and $\mathrm{O}_{2}$. Experimentally, $0.99 \mathrm{mmiol}$ of $\mathrm{N}_{2}$ was observed, which requires the consumption of $1.98 \mathrm{mmol}$ of $\mathrm{NO}_{2}$. NO was detected in two temperature regions at a total quantity of $10.76 \mathrm{mmol}$. Thus, $12.74 \mathrm{mmol}$ of $\mathrm{NO}_{2}^{-}$was required. Alternatively, analytical error may contribute to the offset in the mass balance.

The analysis of the $\mathrm{O}_{2}$ evolution showed $0.15 \mathrm{mmol}$ of $\mathrm{O}_{2}$ produced between $605^{\circ} \mathrm{C}$ and $805^{\circ} \mathrm{C}$. Again, assuming the reactions go to near completion, this quantity is less than the amounts anticipated from transition metal redox reactions in the glass. These temperatures overlap with the NO production, and the $\mathrm{O}_{2}$ evolution can not be separated from the nitrate/nitrite decomposition. Most of the $\mathrm{O}_{2}$

Table 5.3. Offgas Analysis of Nitric Acid pH 4 Sample

\begin{tabular}{|c|c|c|c|c|c|c|}
\hline \multirow[b]{2}{*}{ Sample } & \multirow[b]{2}{*}{ Gas } & \multirow[b]{2}{*}{$\begin{array}{l}\text { Temperature } \\
\text { Range }\left({ }^{\circ} \mathrm{C}\right) \\
\end{array}$} & \multirow[b]{2}{*}{$\begin{array}{l}\text { Amount } \\
\text { (mmol) }\end{array}$} & \multirow[b]{2}{*}{$\begin{array}{l}\text { Possible } \\
\text { Reactions } \\
\end{array}$} & \multicolumn{2}{|c|}{ Starting Chemistry } \\
\hline & & & & & Specie & $\begin{array}{r}\text { Amount } \\
: \text { (mmol) }\end{array}$ \\
\hline $\begin{array}{l}\text { Nitric acid } \\
\mathrm{pH}-4\end{array}$ & $\begin{array}{l}\mathrm{H}_{2} \\
\mathrm{O}_{2}\end{array}$ & $\begin{array}{l}255-443 \\
605-805\end{array}$ & 0.150 & $5.3-5.6$ & $\begin{array}{l}\mathrm{NO}_{3}^{-} \\
\mathrm{NO}_{2}^{-} \\
\mathrm{C}_{2} \mathrm{O}_{4}\end{array}$ & $\begin{array}{c}20.86 \\
7.67 \\
0.033\end{array}$ \\
\hline & $\mathrm{CO}_{2}$ & $\begin{array}{l}149-549 \\
559-819\end{array}$ & $\begin{array}{c}11.7 \\
4.34\end{array}$ & 5.12 & & 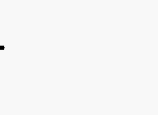 \\
\hline & No & $\begin{array}{l}285-585 \\
625-765\end{array}$ & $\begin{array}{l}9.78 \\
0.980\end{array}$ & 5.4 & & \\
\hline & $\mathrm{N}_{2}$ & $245-525$ & 0.99 & 5.5 & & \\
\hline
\end{tabular}


is attributed to the nitrate/nitrite decomposition. In addition, the reaction sequence (NO evolved, followed by $\mathrm{O}_{2}$ ) corresponds to the observations of Abe et al. (1983) of sodium nitrite and silica behavior between 400 to $700^{\circ} \mathrm{C}$.

\subsection{Nitric Acid pH 4 4X Weight}

This sample was used to elucidate any sample size effects in the gas evolution (see Table 5.4). The nitric acid $\mathrm{pH} 4$ was chosen because the volume expansion (see Section 5.8) was $1.5 \mathrm{~V}_{\mathrm{o}}$ in the $3-\mathrm{g}$ sample, and thus could be measured with the existing experimental apparatus. . The starting volume of the 12-g sample was approximately three times greater than the starting volume of the analogous $3-\mathrm{g}$ sample.

Examination of the evolved $\mathrm{CO}_{2}$ showed a measured excess compared to the reactants present, $\mathrm{CO}_{3}^{2-}$ and $\mathrm{C}_{2} \mathrm{O}_{4}^{2-}$. This behavior also was observed in the analogous 3-g sample. Therefore, a mass balance for $\mathrm{CO}_{2}$ was not possible. A side reaction that produced $0.4 \mathrm{mmol}$ of $\mathrm{CO}$ was detected over the temperature range $135^{\circ} \mathrm{C}$ to $485^{\circ} \mathrm{C}$. The $0.4 \mathrm{mmol}$ of $\mathrm{CO}$ was approximately four times the amount produced in the analogous 3-g sample.

The 3-g nitric acid pH 4 sample showed less than stoichiometric nitrate/nitrite decompositions. The analogous $12-\mathrm{g}$ sample produced $\mathrm{NO}$ and $\mathrm{N}_{2}$ in quantities significantly less than the amounts expected from fully decomposed reactants. Again, assuming nitrate conversion to nitrite, $114 \mathrm{mmol}$ of $\mathrm{NO}_{2}$ were available as reactant. Experimentally, $33.27 \mathrm{mmol}$ of $\mathrm{NO}$ and $3.21 \mathrm{mmol}$ of $\mathrm{N}_{2}$ were observed. These products require only $39.7 \mathrm{mmol}$ of $\mathrm{NO}_{2}$. The side reaction that produced $\mathrm{N}_{2}$ yielded approximately three times the $\mathrm{N}_{2}$ rather than the four times quantity expected on the sample weight basis. Therefore, the size of the sample may have changed the gases which were detected.

Table 5.4. Offgas Analysis of $4 \mathrm{X}$ Weight Nitric Acid pH 4

\begin{tabular}{|c|c|c|c|c|c|c|}
\hline \multirow[b]{2}{*}{ Sample } & \multirow[b]{2}{*}{ Gas } & \multirow[b]{2}{*}{$\begin{array}{l}\text { Temperature } \\
\text { Range }\left({ }^{\circ} \mathrm{C}\right)\end{array}$} & \multirow[b]{2}{*}{$\begin{array}{l}\text { Amount } \\
\text { (mmol) }\end{array}$} & \multirow[b]{2}{*}{$\begin{array}{c}\text { Possible } \\
\text { Reactions }\end{array}$} & \multicolumn{2}{|c|}{ Starting Chemistry } \\
\hline & & & & & Specie & $\begin{array}{l}\text { Amount } \\
\text { (mmol) }\end{array}$ \\
\hline $\begin{array}{l}\text { Nitric acid } \\
\mathrm{pH} \sim 4 \\
4 \mathrm{X} \text { wt }\end{array}$ & $\begin{array}{l}\mathrm{H}_{2} \\
\mathrm{O}_{2}\end{array}$ & $\begin{array}{c}\text { none } \\
446-746\end{array}$ & 0.34 & $5.3-5.6$ & $\begin{array}{l}\mathrm{NO}_{3}^{-} \\
\mathrm{NO}_{2}^{-} \\
\mathrm{C}_{2} \mathrm{O}_{4}^{2-}\end{array}$ & $\begin{array}{c}\ddot{83} .44 \\
30.68 \\
0.132\end{array}$ \\
\hline & $\mathrm{CO}_{2}$ & $\begin{array}{l}109-449 \\
109-299 \\
299-449 \\
449-719\end{array}$ & $\begin{array}{l}39.2 \\
18.6 \\
20.6 \\
18.5\end{array}$ & 5.12 & . & \\
\hline & No & $\begin{array}{l}109-506 \\
576-776\end{array}$ & $\begin{array}{c}30.6 \\
2.67\end{array}$ & 5.4 & & \\
\hline & $\mathrm{N}_{2}$ & $105-485$ & 3.214 & 5.5 & & \\
\hline
\end{tabular}


Presumably, a larger sample created a larger path length for the products expulsion from the sample. Further, a continuous viscous glass was likely formed at temperatures similar to the 3-g sample; this glass could have entrapped some of the expected $\mathrm{NO}$ and $\mathrm{N}_{2}$.

Comparison of the temperature ranges and gas peak profiles adds insight. The $\mathrm{N}_{2}$ production ceased $40^{\circ} \mathrm{C}$ earlier in the larger sample, and the NO production was observed in two peaks for both samples. However, both peak ranges in the $12 \mathrm{~g}$ were observed to begin and end at lower temperatures. In addition, the $109^{\circ} \mathrm{C}$ to $506^{\circ} \mathrm{C}$ peak (refer to Appendix $\mathrm{A}$ ) in the $12-\mathrm{g}$ sample was much broader and diffuse, which may indicate the influence of the larger sample's increased path length. Based on the differences in observed quantities of $\mathrm{NO}$ and $\mathrm{N}_{2}$, peak profile, and temperature ranges, the size of sample was shown to affect the nitrate/nitrite decomposition.

A comparison of the produced oxygen showed an approximate ratio of 2:1 instead of the expected 4:1 ratio (12 g:3 g). The observed temperature range for the $12-\mathrm{g}$ sample was $446^{\circ} \mathrm{C}$ to $746^{\circ} \mathrm{C}$, which nas lower and broader than the $605^{\circ} \mathrm{C}$ to $805^{\circ} \mathrm{C}$ range for the $3-\mathrm{g}$ sample. For both samples; the produced oxygen behaved similarly to the nitrate/nitrite decomposition. Thus, the scaling effect was prevalent in the $\mathrm{O}_{2}$ yield; suggesting that the quantity of gas evolved in the laboratory-scale may be more than the quantity expected for large-scale tests.

\subsection{Nitric Acid pH 6 Melter Feed}

Table 5.5 shows the gas analysis for the melter feed sample acidified with nitric acid to $\mathrm{pH} 6$. The decomposition of $\mathrm{C}_{2} \mathrm{O}_{4}^{-}$did not result in the detection of stoichiometric quantities of $\mathrm{CO}_{2}(4.4 \mathrm{mmol}$ detected). The decomposition of the nitrate/nitrite resulted in $6.4 \mathrm{mmol}$ of NO. However, if reactions (5.3) to (5.5) went to completion, $6.8 \mathrm{mmol}$ of $\mathrm{NO}$ would have been produced. The nitrogen lacking in the heat treatment mass balance may be present in the glass network or a result of analytical error.

Table 5.5. Offgas Analysis for Nitric Ácid pH6 Sample

\begin{tabular}{|c|c|c|c|c|c|c|}
\hline \multirow[b]{2}{*}{ Sample } & \multirow[b]{2}{*}{ Gas } & \multirow[b]{2}{*}{$\begin{array}{l}\text { Temperature } \\
\text { Range }\left({ }^{\circ} \mathrm{C}\right)\end{array}$} & \multirow[b]{2}{*}{$\begin{array}{l}\text { Amount } \\
\text { (mmol) }\end{array}$} & \multirow[b]{2}{*}{$\begin{array}{l}\text { Possible } \\
\text { Reactions }\end{array}$} & \multicolumn{2}{|c|}{ Starting Chemistry } \\
\hline & & & & & Specie & $\begin{array}{l}\text { Amount } \\
\text { (mmol) }\end{array}$ \\
\hline \multirow{6}{*}{$\begin{array}{l}\text { Nitric acid } \\
\mathrm{pH}-6\end{array}$} & $\mathrm{H}_{2}$ & none & & . & $\mathrm{NO}_{3}^{-}$ & 3.26 \\
\hline & $\mathrm{O}_{2}$ & $433-753$ & 0.432 & $5.3-5.6$ & $\mathrm{NO}_{2}^{-}$ & 3.51 \\
\hline & $\mathrm{CO}_{2}$ & $116-757$ & 4.38 & $5.12,5.1$ & $\mathrm{C}_{2} \mathrm{O}_{4}$ & 0.033 \\
\hline & No & $113-773$ & 6.40 & 5.4 & & \\
\hline & $\mathrm{CO}$ & none & & & 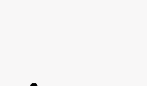 & . \\
\hline & $\mathrm{N}_{2}$ & none & & & & \\
\hline
\end{tabular}


From the volume expansion data (see Section 5.8), it was observed that the sample volume of nitric acid samples decreases initially, then subsequently increases. This initial decrease in volume is much more dramatic than the non-nitric acid samples. Presumably, during this decrease in volume, the liquid phase becomes continuous. Therefore, the decomposition products, $\mathrm{NO}$ and $\mathrm{CO}_{2}$ (Parker et al. 1993) may be trapped more readily as soluble species in the glass. Alternatively, the nitrite decomposition may yield $\mathrm{N}_{2}$ (undetected), which is readily soluble in glass (Gausman et al. 1993). The incorporation of the decomposition products as soluble species may account for the less than stoichiometric detection of the decomposition reactions described previously. Alternatively, analytical error can contribute to the less than perfect mass balance.

The nitric acid pH 6 sample produced $0.43 \mathrm{mmol}$ of $\mathrm{O}_{2}$. The temperature regime $\left(433^{\circ} \mathrm{C}\right.$ to $753^{\circ} \mathrm{C}$ ) of oxygen production overlaps with the nitrate/nitrite decomposition temperature range. Again, the oxygen was not detected in quantities attributable to transition metal redox reactions. Therefore, the acidification to $\mathrm{pH} 6$ with nitric acid did not primarily influence the oxygen evolution due to transition metal redox reactions. However, the quantity of $\mathrm{O}_{2}$ produced did exceed the formated and unformated samples. Additional $\mathrm{O}_{2}$ likely evolved from the nitrate/nitrite decomposition.

\subsection{Sugar with $\mathrm{HNO}_{3} \mathrm{pH} 6$}

Sugar can decompose when heated in an oxygen-containing atmosphere by a variety of mechanisms and routes. To correspond with the experimentally measured gases, the following stoichiometric . reactions were considered:

$$
\begin{aligned}
& \overrightarrow{\mathrm{C}}_{12} \mathrm{H}_{22} \mathrm{O}_{11}+12 \dot{\mathrm{O}_{2}} \rightarrow 12 \mathrm{CO}_{2}+11 \mathrm{H}_{2} \mathrm{O} \\
& \mathrm{C}_{12} \mathrm{H}_{22} \mathrm{O}_{11}+\frac{1}{2} \mathrm{O}_{2} \rightarrow 11 \mathrm{H}_{2}+12 \mathrm{CO}
\end{aligned}
$$

and

$$
\mathrm{C}_{12} \mathrm{H}_{22} \mathrm{O}_{11} \rightarrow 12 \mathrm{C}+11 \mathrm{H}_{2} \mathrm{O}
$$

A variety of other decomposition reactions are possible that include the production of methane or ethane. Since reactions (5.14) through (5.16) simplify the decomposition of sugar, and products other than those listed are possible, a mass balance based on $\mathrm{CO} / \mathrm{CO}_{2}$ is difficult. Therefore, the mass balance begins with the examination of the available $\mathrm{O}_{2}$ from the nitrate/nitrite decompositions. Assuming all the nitrate decomposes to nitrite and subsequently, reaction (5.5) was followed, then $13.42 \mathrm{mmol}$ of $\mathrm{O}_{2}$ would be available for reactions (5.14) and (5.15). The gas analysis showed that $3.3 \mathrm{mmol}$ of NO were produced [which indicates reaction (5.4) was observed in part] and the total possible oxygen yield was reduced to $7.99 \mathrm{mmol}$. This assumes that reaction (5.3) went to completion. 
Consider the production of $\mathrm{CO}_{2}$ from sugar decomposition while assuming an oxygen limitation. Between $136^{\circ} \mathrm{C}$ and $696^{\circ} \mathrm{C}, 71.4 \mathrm{mmol}$ of $\mathrm{CO}_{2}$ were detected. According to equation (5.14), $71.4 \mathrm{mmol}$ of $\mathrm{O}_{2}$ were required for this decomposition mechanism. Oxygen was surely supplied by the nitrate/nitrite decomposition which occurs in a similar region. The quantity of $\mathrm{O}_{2}$ produced cannot be determined, therefore, a mass balance for $\mathrm{H}_{2}, \mathrm{CO}$, and $\mathrm{CO}_{2}$ could not be constructed with the available information.

Examination of the data (Table 5.6) showed that a greater amount of $\mathrm{H}_{2}$ was detected compared to CO. Likely, reaction (5.15) was observed, but $C O$ participated in subsequent reactions. A comparison of the $\mathrm{CO}$ and $\mathrm{H}_{2}$ between $665^{\circ} \mathrm{C}$ and $1200^{\circ} \mathrm{C}$, showed 1.404 and $0.589 \mathrm{~mol}$, respectively. Reaction (5.16) may have provided the reactants for

$$
\mathrm{C}+\mathrm{H}_{2} \mathrm{O} \rightarrow \mathrm{CO}+\mathrm{H}_{2}
$$

which was observed at higher temperatures and cited in Dickerson et al. (1979).

Table 5.6. Offgas Analysis of Sugar $w / \mathrm{HNO}_{3}$ Sample

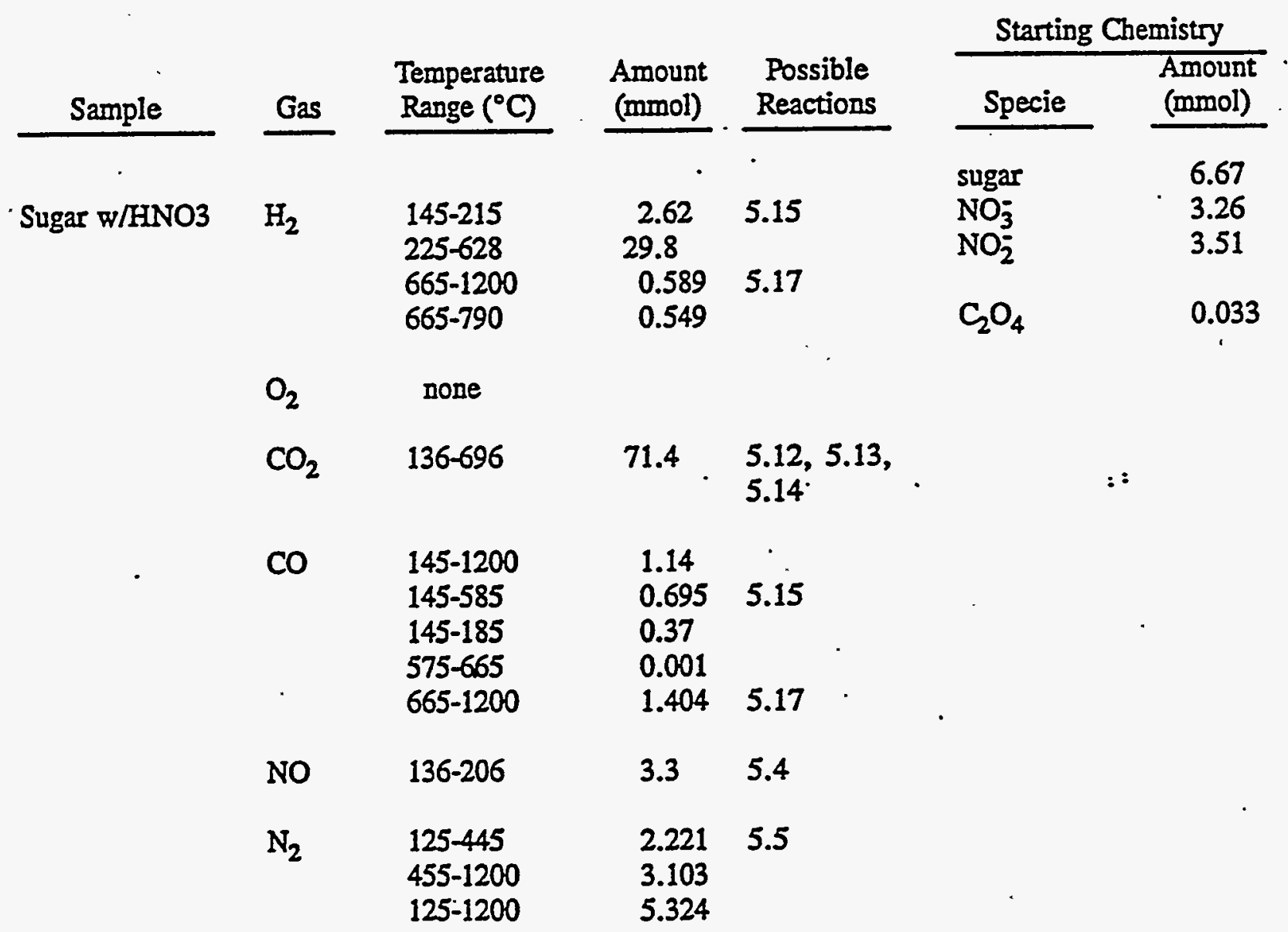




\subsection{Oxide/Carbonate Melter Feed}

The preparation of melter feed from oxides, carbonates, and boric acid produces a sample without reductants. Corresponding to the absence of any chemical treatment, the only decomposition gas observed was $\mathrm{CO}_{2}$. The starting sample contained $12.7 \mathrm{mmol}$ of $\mathrm{CO}_{3}^{-}$, which completely decomposed in the temperature range between $455^{\circ} \mathrm{C}$ and $785^{\circ} \mathrm{C}$. The majority of the $\mathrm{CO}_{2}(12.7 \mathrm{mmol})$ was observed between $605^{\circ} \mathrm{C}$ and $785^{\circ} \mathrm{C}$. A total of $14.1 \mathrm{mmol}$ of $\mathrm{CO}_{2}$ was observed with the excess (1.4 mmol) attributed to adsorbed $\mathrm{CO}_{2}$.

\subsection{Iron Redox State}

Figure 5.1 was plotted assuming Arrhenius behavior and shows that the Fe(II)/2Fe redox measurement is temperature dependent. The differences within a temperature range are most likely. experimental error. Specifically, the average $\mathrm{Fe}(\mathrm{II}) / \mathrm{LFe}$ ratio was $0.0024 \pm 0.0012$ for the $1000^{\circ} \mathrm{C}$ measurements from the formated, unformaied, and nitric acid samples. The average $\mathrm{Fe}(\mathrm{II}) / \Sigma \mathrm{Fe}$ ratio was $0.032 \pm 0.014$ for the $1200^{\circ} \mathrm{C}$ measurements from the formated, unformated, nitric acid, and oxide/carbonate samples. The sugar containing samples showed a significant difference in redox ratio compared to the previously described samples. Specifically, a sample containing $1 \mathrm{~mol}$ of sugar showed a redox ratio of 0.58 at $1000^{\circ} \mathrm{C}$, and a sample containing $2.8 \mathrm{mmol}$ produced an average ratio of 0.79 at $1200^{\circ} \mathrm{C}$. Presumably, sugar reduced nitrate and nitrite and decomposed to $\mathrm{C}$ or an intermediate compound which reduced Fe(III) at higher temperatures. Thus, sugar caused the Fe redox

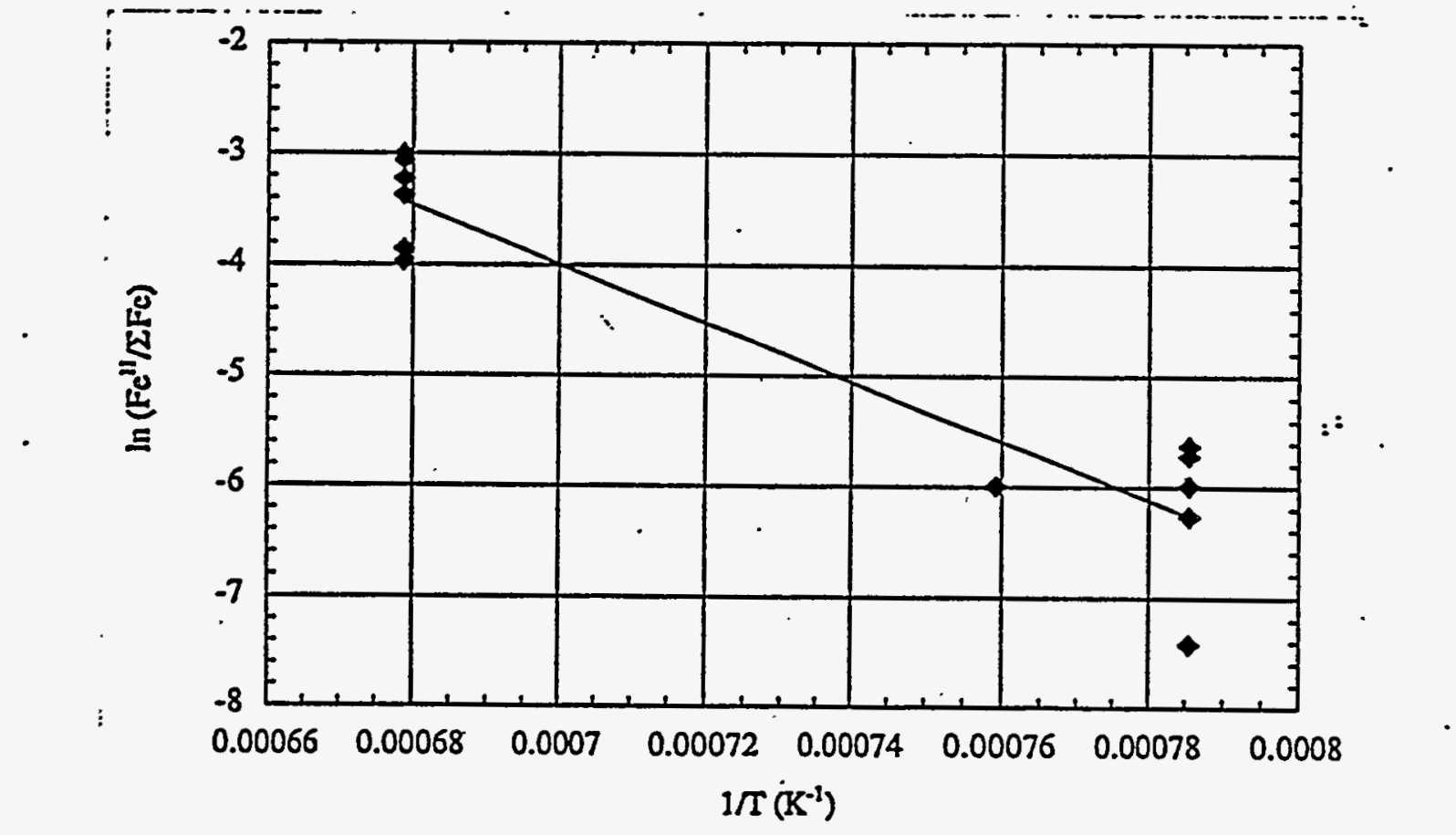

Figure 5.1. Iron Redox Measurement 
state of the glass to be reduced. Assuming equation (5.16), the sugar decomposed to produce $C$, which ultimately reduced the transition metals in the glass and consumed any $\mathrm{O}_{2}$ present (Table 5.6).

\subsubsection{Evaluation of Empirical Redox Models}

Equations (3.4 and 3.5) were developed using data from glasses melted and quenched from $1100^{\circ} \mathrm{C}$. These models predict $\mathrm{Fe}$ redox in the range of 0.03 for glasses quenched from $1100^{\circ} \mathrm{C}$. The measured iron redox for this experimentation was 0.00238 at $1000^{\circ} \mathrm{C}$ and 0.0320 at $1200^{\circ} \mathrm{C}$. Interpolation to $1100^{\circ} \mathrm{C}$ yields an iron redox ratio of 0.0087 . The [F-N] for the formated melter feed is $0.3664 \mathrm{M}$ which is less than the minimum $(0.92)$ required for evaluation of equation 3.4. Equation 3.5 provides agreement for the empirical model. However, this agreement is likely fortuitous, because the model is based on closed-crucible tests that maintain the atmosphere produced during heating. It is unlikely that higher concentrations of formate would show correspondence with this model for the described experiment.

The redox ratios were plotted versus IFO for the samples described in Table 5.7. Figures 5.2A and 5.2B do not show a correlation of the iron redox ratio with feed chemistry. This model is not applicable for interpretation of these experiments. Furthermore, Figures 5.2A and 5.2B suggest that the iron redox was independent of the starting chemistry for the formated, unformated, and nitric acid samples.

\subsection{Volume Expansion of Melter Feeds}

The normalized volume expansion of the melter feeds is shown in Figures 5.3A and 5.3B and a summary in Table 5.8. There is clearly a difference in volume expansion between the samples with different starting chemistry. The sugar sample will be discussed first followed by a comparison of the other samples.

The sugar sample expanded rapidly at much lower temperatures compared to the other samples. The temperature of the sugar expansion corresponds to the time sugar decomposition products appear in the offgas (refer to Table 5.6). By meiting at $176^{\circ} \mathrm{C}$, sugar forms a continuous molten phase, which may allow faster reaction within the waste and trapping evolved gases. The gas produced for the sugar sample exceeded the volumes observed for the other samples.

A comparison of the formated, unformated, and nitric acid samples showed significant differences in the expansion volumes. The temperature region of the expansion was approximately $720^{\circ} \mathrm{C}$ to $890^{\circ} \mathrm{C}$. However, the nitric acid samples showed a shrinkage between $720^{\circ} \mathrm{C}$ and $800^{\circ} \mathrm{C}$. This behavior is not as prevalent in the formated and unformated samples. Examination of the gases detected during the temperature regions corresponding and adjacent to the expansion temperatures provided relevant information. Comparing the formated, unformated, and nitric acid samples and summing the gas quantities for the temperature regions that correspond to the expansion range showed that the least gas was detected for the formated sample, which expanded the most. The unformated sample was intermediate in both gas detected and foam. The nitric acid sample expanded the least but produced the most gas volume. This behavior points toward a difference in physical properties of the batch based on the starting chemistry, rather than a gas-volume expansion relationship. 
Table 5.7. Summary of Iron Redox Data

\begin{tabular}{|c|c|c|}
\hline Sample & $\begin{array}{c}\text { Temperature } \\
\left({ }^{\circ} \mathrm{C}\right)\end{array}$ & $\mathrm{Fe} \mathrm{II/Fe} \mathrm{Total}$ \\
\hline Formic Acid & 1000 & 0.0019 \\
\hline Formic Acid & 1000 & 0.0033 \\
\hline Formic Acid & 1200 & 0.0498 \\
\hline Unformated & 1000 & 0.0036 \\
\hline Unformated & 1000 & 0.0006 \\
\hline Unformated & 1044 & 0.0025 \\
\hline Unformated & 1200 & 0.0189 \\
\hline Nitric pH4 & 1000 & 0.0025 \\
\hline Nitric pH4 & 1200 & 0.0343 \\
\hline Nitric pH4 & 1200 & 0.0398 \\
\hline Nitric pH4 4X wt & 1200 & 0.0211 \\
\hline Nitric pH6 & 1200 & 0.0468 \\
\hline Oxide/Carbonate & 1200 & 0.0142 \\
\hline Sugar $1 \mathrm{M}$ & 1000 & 0.5841 \\
\hline Sugar $\mathrm{HNO}_{3} \mathrm{pH} 4$ & 1200 & 0.7737 \\
\hline Sugar $\mathrm{HNO}_{3} \mathrm{pH} 4$ & 1200 & 0.8044 \\
\hline
\end{tabular}

The oxide/carbonate melter feed produced expansion between $743^{\circ} \mathrm{C}$ and $894^{\circ} \mathrm{C}$. This range approximately matches that observed for the formic, nitric, and unformated melter feeds. The oxide/ carbonate batch attained a maximum volume of $2 \mathrm{~V}_{0}$. During the expansion, a small quantity of $\mathrm{CO}_{2}$ $(0.004 \mathrm{mmol})$ was detected. Unfortunately, this does not clarify a relationship between expansion volume and gas quantity.

The nitric acid $4 \mathrm{X}$ weight sample provides an indication of expansion scaling effects for these experiments (see Figure 5.3B). The $4 \mathrm{X}$ weight sample expanded in two regions. The first region was $160^{\circ} \mathrm{C}$ to $763^{\circ} \mathrm{C}$. This small expansion may be attributed to decrepitation of the feed, which was only observable on the $4 \mathrm{X}$ weight sample. For the second region, the $4 \mathrm{X}$ weight sample attained nearly three times its original volume, $\vec{V}_{o}$, whereas the $3-g$ nitric acid samples expanded to approximately 1.5 $\mathrm{V}_{\mathrm{o}}$. The gas quantity detected for the expansion of the $4 \mathrm{X}$ weight sample was significantly less than the 3-g nitric acid sample. More gas was trapped in the $4 \mathrm{X}$ weight sample, and the $3 \mathrm{~V}_{0}$ expansion resuited. 


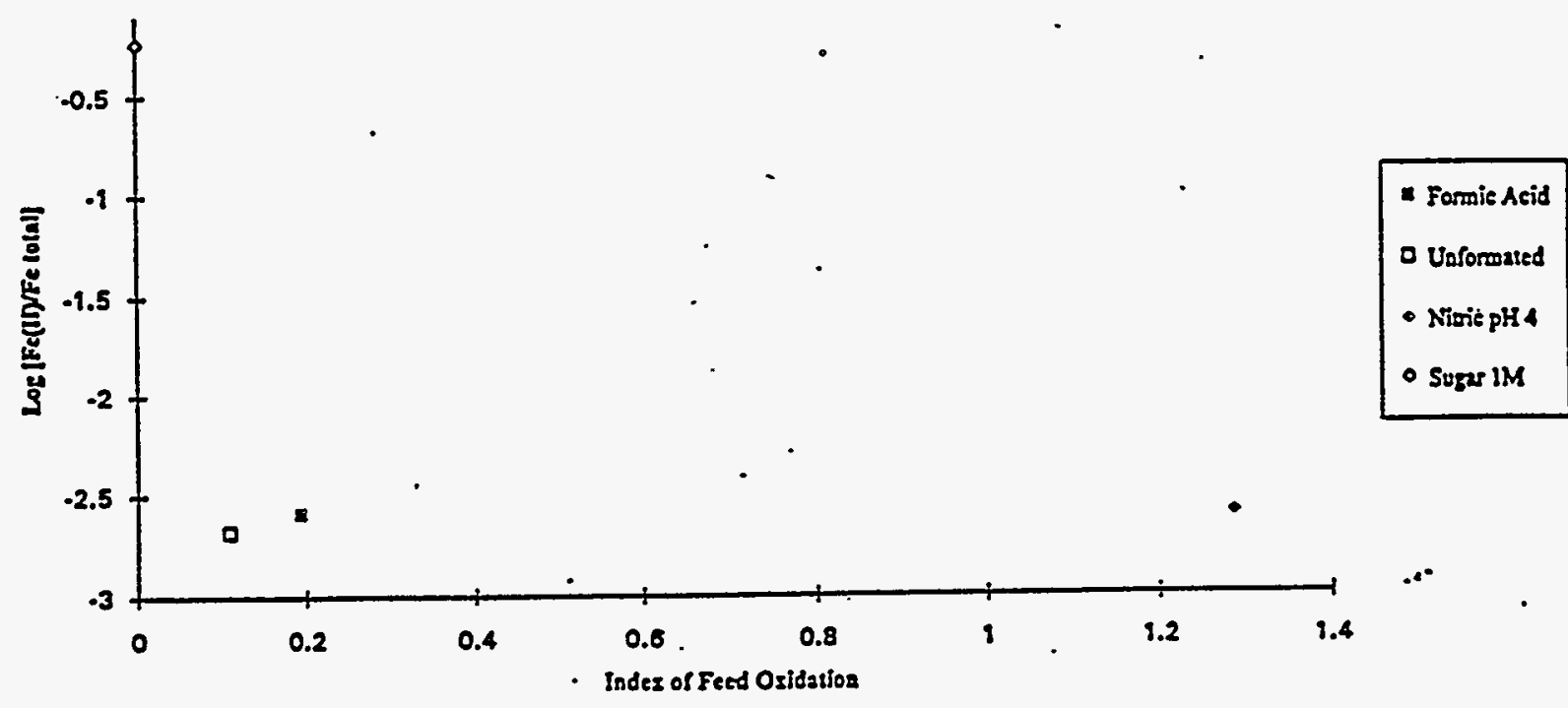

Figure 5.2A.. Iron Redox Ratio as a Function of the Feed Oxidation Index for $1000^{\circ} \mathrm{C}$

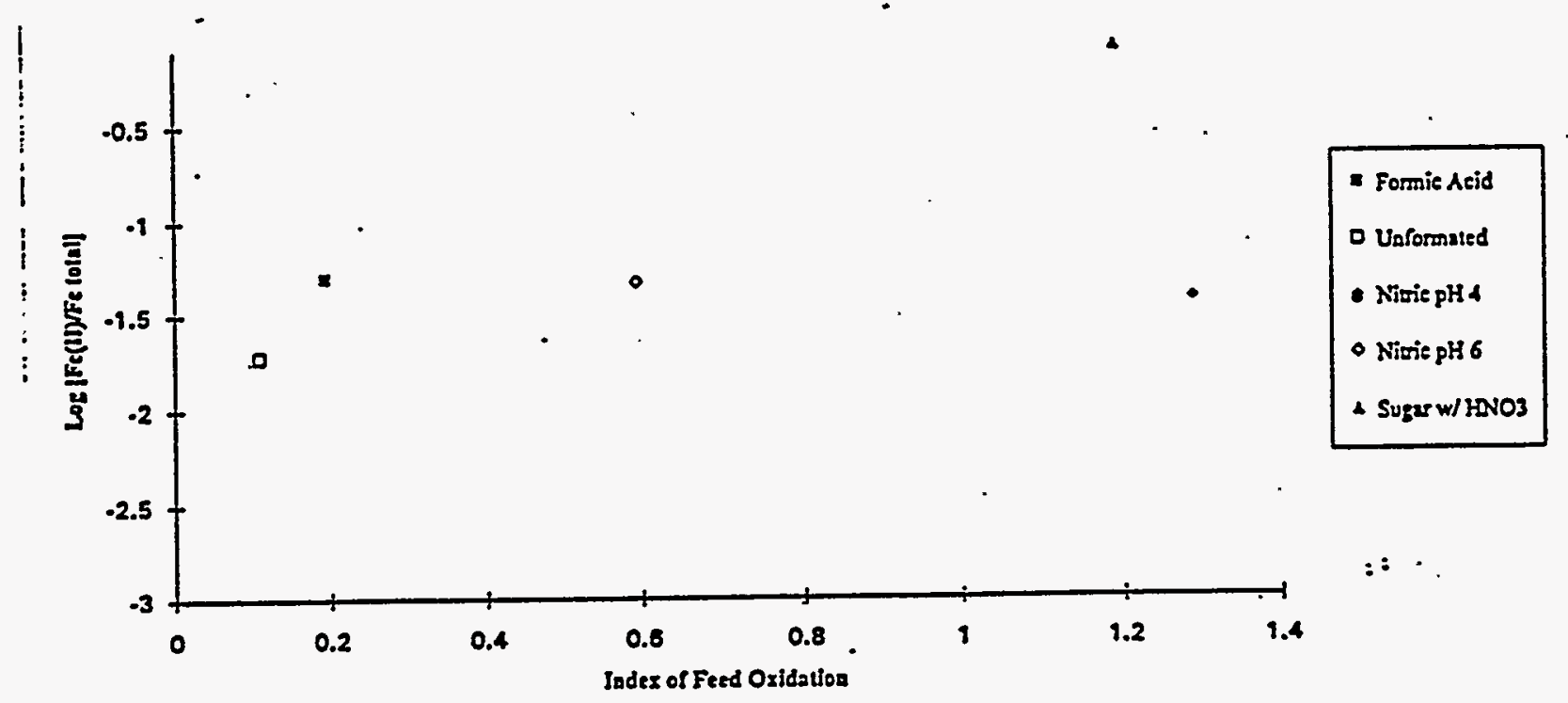

Figure 5.2B. Iron Redox Ratio as a Function of the Feed Oxidation Index for $1200^{\circ} \mathrm{C}$ 


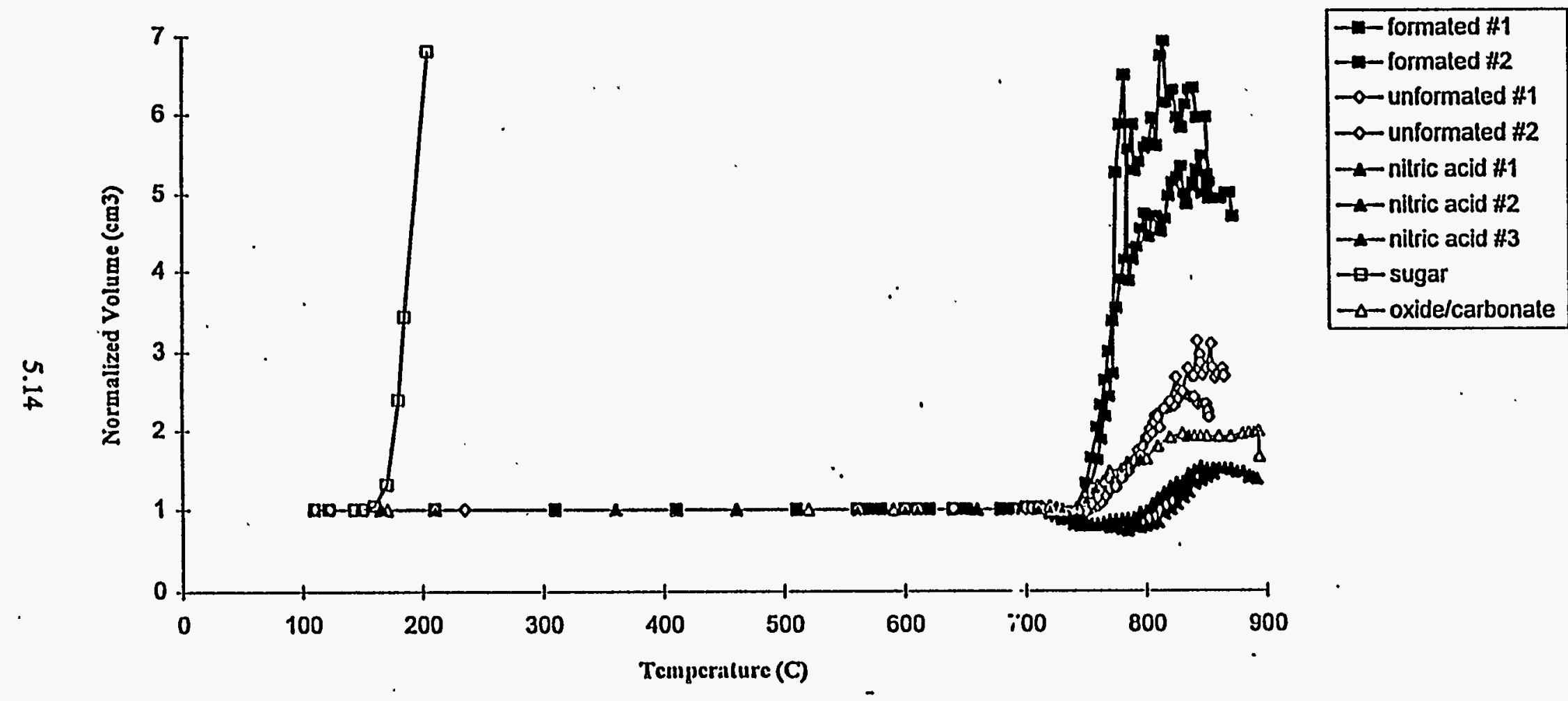

Figure 5.3A. Volume Expansion of Batch Material as a Function of Temperature. A normalized volume of 5 corresponds to an expansion of 5 times the original volume. 


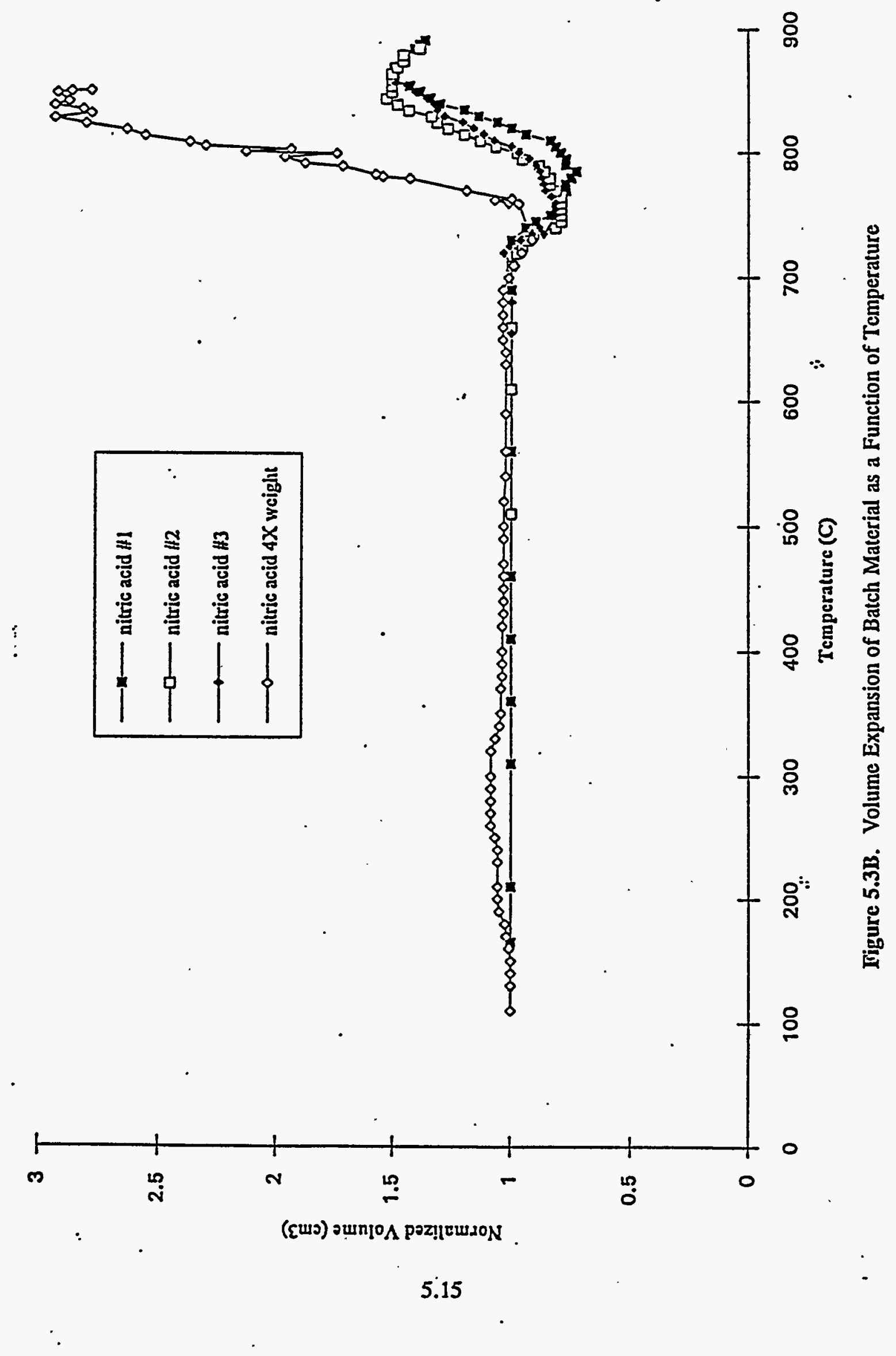


Table 5.8. Volume Expansion Summary

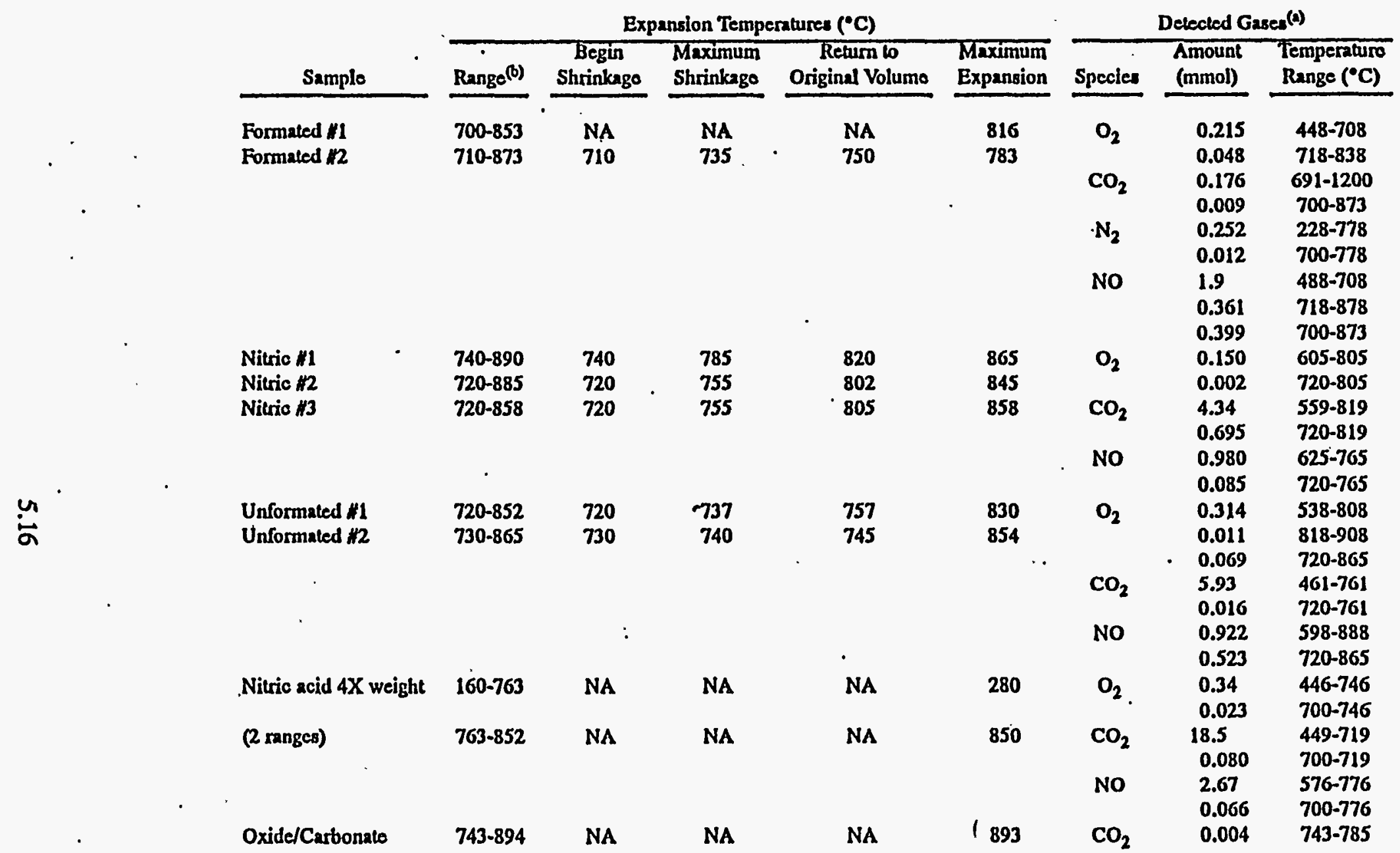

(a) Only one measurementiof the gas products was obtained. The A Figures in Appendix A are representative of the first sample for reperted lests.

(b) Expansion temperalure range corresponds to recorded deviation of normalized volume from $1 \mathrm{~cm}^{3}$. 


\subsubsection{Possible Explanation for Volume Expansion Differences}

The differences in volume expansion of the batch materials for the untreated, formic acid, nitric acid and oxide/carbonate samples has not been explained. The current data may be used to suggest a possible mechanism. The starting chemistry is the primary variable for these samples and is known to affect reaction paths in glass-making. Examination of the gas data with respect to reaction paths and volume expansion may allow an explanation.

The $\mathrm{H}_{2}$ from the decomposition of formic acid or sodium formate (in the formic acid sample) was observed below $400^{\circ} \mathrm{C}$. One of the possible reaction products, $\mathrm{Na}_{2} \mathrm{O}$ may attack the frit to form a highly viscous melt at relatively !ow temperatures. The highly reactive $\mathrm{Na}_{2} \mathrm{O}$ would vigorously react with the remaining batch. The presence of batch material may lower the viscosity of the melt or destabilize the foam lamellae. The proposed reaction path for the formic acid sample results in a highly viscous imelt at low temperatures and the disappearance of residual refractory materials at lower temperatures (relative to the other samples). The highly viscous melt may retain the product"gases and resulted in the $6.5 \mathrm{~V}_{0}$ expansion. The absence of batch materials may stabilize the foam which allows more expansion to occur before collapse.

The untreated and nitric acid samples contain significant quantities of $\mathrm{NO}_{3}^{-}$which forms molten sodium nitrate (low viscosity) at low temperatures. For the oxide/carbonate sample, low viscosity molten sodium carbonate is the first continuous phase formed. The presence of molten sodium nitrate phase can be judged from the end temperature of the NO detection. For the untreated sample, the temperature was $888^{\circ} \mathrm{C}$ and for the nitric acid sample, $765^{\circ} \mathrm{C}$ was the temperature. For the oxidel carbonate sample, the last $\mathrm{CO}_{2}$ detected was $785^{\circ} \mathrm{C}$ which reflects the presence of the molten sodium carbonate phase. A case can be made for the presence of low viscosity molten phases in the untreated, nitric acid and oxide/carbonate samples. The presence of molten salts implies that a viscous sodium silicate did not form because highly reactive $\mathrm{Na}_{2} \mathrm{O}$ was not present in appreciable quantity. This proposed reaction path also implies the presence of refractiory materials at higher (compared to formic acid) temperatures. Thus, the relatively lower volume expansions for the untreated, nitric acid and oxide/carbonate samples may be the result of reaction paths which maintained a low viscosity molten phase. In addition, the presence of batch materials at higher temperatures may have destabilized foam lamellae or lowered viscosity, and ultimately, prevented further volume expansion. 


\subsection{Comparison of Glass Redox Prepared by Quartz Melter and Pilot-Scale Ceramic Melter Tests}

The redox data obtained in this study were compared with laboratory-scale, ${ }^{(a)}$ pilot-scale (Goles et al. 1990), and large-scale tests. ${ }^{(a)}$ All data were normalized to compare starting chemistry and glass redox. The quantities of total carbon, nitrate, nitrite, formate, and carbonate concentrations are reported in M/L @ $130 \mathrm{gWO} / \mathrm{L}$ or $\mathrm{M} / 130 \mathrm{gWO}$. These normalized composition have been used to compute an iron redox index (ri) given in equations 6.1 and 6.2. The results of the comparison are summarized in Figure 6.1. This index has been developed through analysis of glasses made at $1000^{\circ} \mathrm{C}$ (Merz) $^{(a)}$ and (Wiemers): ${ }^{(b)}$

$$
\mathrm{ri}=\frac{\mathrm{COOH}^{-}-\mathrm{NO}_{2}^{-}+\mathrm{C}}{\mathrm{NO}_{3}^{-}}
$$

for formated samples, or

$$
\mathrm{ri}=\frac{\mathrm{C}}{\mathrm{NO}_{2}^{-}+\mathrm{NO}_{3}^{-}}
$$

for unformated samples.

In the redox index range of 1 to 3, the quartz melter glass redox values were slightly lower than the PSCM data. The correlation improved based on the dried feed analyses compared to the slurry target composition (initial composition). The effect of drying has not been studied, and the improvement may be fortuitous. However, for the formic acid test, some of the formate ion remaining after feed preparation may have been lost in the drying process, which would explain why the redox is low bäsed on the "initial" composition compared to the "dried" composition. From other similar feed preparation tests, ${ }^{(c)} 0.9 \mathrm{M} \mathrm{COOH}$ would be expected in the feed, compared to the value 0.65 measured for the dried feed. This behavior requires additional testing and analyses of feed before the drying step to resolve this issue.

(a) Merz, M. D. 1993. A Summary Report on Feed Preparation Offgas and Glass Redox Data for Hanford Waste Vitrification Plant. Technical Report PHTD-C93-03.02L, Pacific Northwest Laboratory, Richland, Washington.

(b) Wiemers, K. D. 1990. The Effect of HWVP Feed Nitrate and Carbonate Content on Glass Redox Adjustment. Technical Report to Westinghouse Hanford Company, Milestone PHTD-C93-03.02b, Pacific Northwest Laboratory, Richland, Washington.

(c) Smith et al. 1993. Draft Report FY 1992 Studies. 


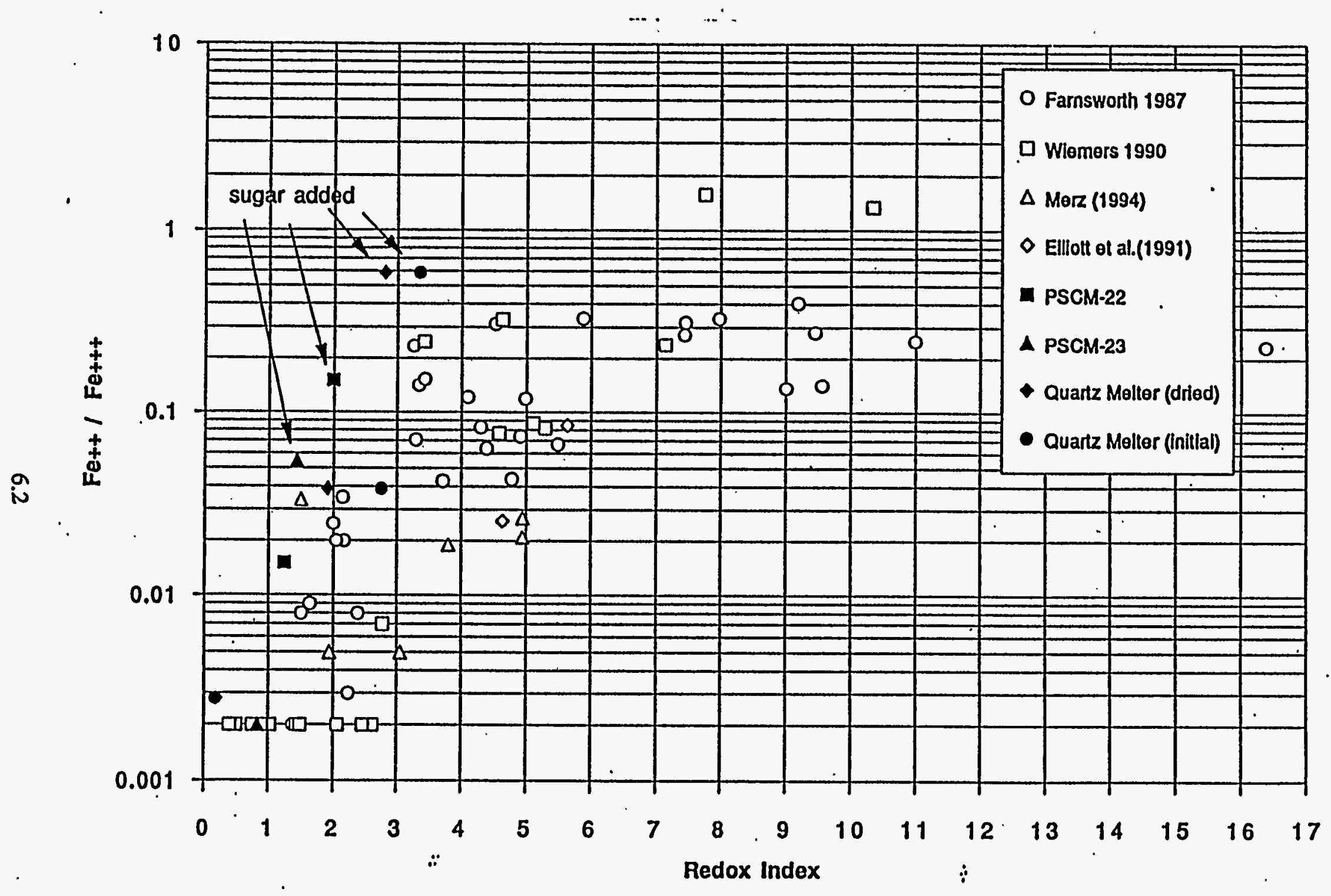

Figure 6.1. Summary of Redox Comparison. The quartz melter initial and dried terms refer to the slurry chemistry and the chemistry determined after liquid removal, respectively. 
With large amounts of sugar added, the iron redox ratios measured in this study were much higher than the PSCM tests, primarily because the amount of added sugar was considerably higher. The results were consistent with the large-scale tests but could not be compared directly. Further, laboratory-scale tests reported by Goles et al. (1990) indicated redox would be expected to be above 0.5 from extrapolation of data on feeds with smaller amounts of added sugar.

\subsection{Comparison of $\mathrm{CO}_{2}, \mathrm{H}_{2}, \mathrm{~N}_{2}$, and $\mathrm{NO}_{\mathrm{x}}$ Offgas for Quartz Melter and Pilot-Scale Ceramic Melter Tests}

The offgas data from this study were compared with the PSCM melter test 23 data (Goles et al. 1990). These data were compared on the basis of total carbon, total nitrogen and total hydrogen (excluding water). The basis for the inventory of each of these elements was derived from the data in Table 6.1, using the dried feed analyses for the quartz melter results. All data were normalized on the basis of $\mathrm{mM} / \mathrm{L}$ final meiter feed $(\sim 130 \mathrm{gWO} / \mathrm{L}$ for quartz melter and $125 \mathrm{gWO} / \mathrm{L}$ for the

Table 6.1. Feed Compositions for Comparison

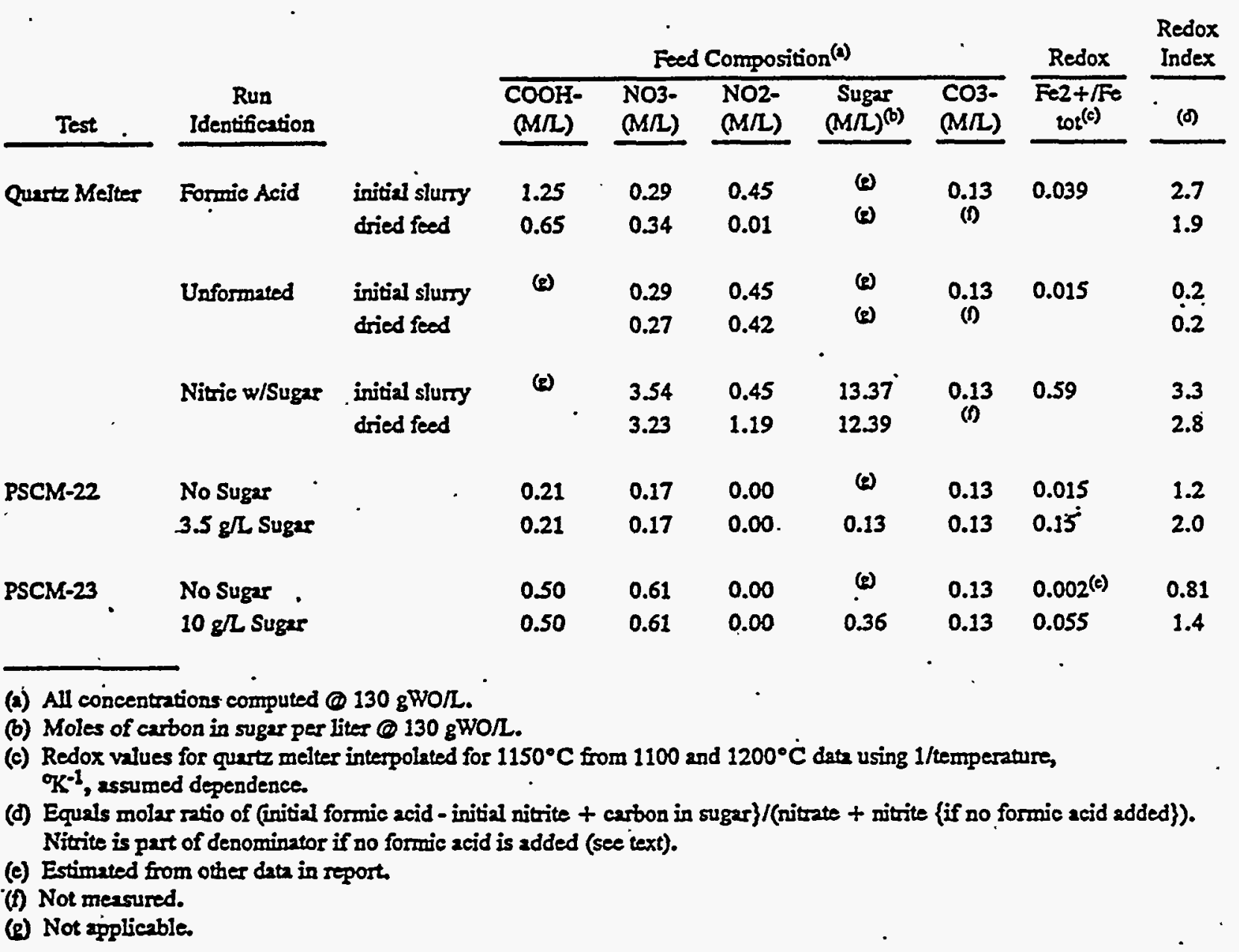


PSCM-23 test). The results are shown in Figures 6.2, 6.3 and 6.4. The amounts of offgas predicted by total amounts of carbon, hydrogen and nitrogen in the feed are indicated by.dashed lines. The data for $\mathrm{CO}_{2}$ offgas were nearly the same for the two tests for formated feed, but were considerably higher than the total carbon in the feed would predict. The carbon content of the feed is likely increased by the formation of sodium carbonate during drying from sodium in the waste slurry and atmospheric carbon dioxide. The quantity of $\mathrm{CO}_{2}$ detected was in greater excess for the unformated feed. The quartz melter nitric w/sugar test yielded $\mathrm{CO}_{2}$ in quantities equivalent to the carbon content. However, a significant quantity of $\mathrm{CO}$ was also detected in the nitric w/sugar test.

The amount total $\mathrm{H}_{2}$ offgas for the quartz melter was less than the amount of total $\mathrm{H}$ in the feed. For the two most directly comparable tests, PSCM-23 and the formated feed quartz melter test, the tests produced a nearly equal quantity of $\mathrm{H}_{2}$. Approximately $50 \%$ of the total $\mathrm{H}$ in the feed was measured as $\mathrm{H}_{2}$ offgas for the PSCM test. One third of the total hydrogen in the feed was measured as $\mathrm{H}_{2}$ for the quartz melter test. For the nitric w/sugar quartz melter test, the amount of $\mathrm{H}_{2}$ offgas. \#yas about an order of magnitude below the amount of $\mathrm{H}$ in the slurry. No large-scale data were available for feeds containing large quantities of sugar and glasses with a similar composition; therefore, comparison for this feed composition was not made. Further analysis should be done to provide a better basis for. predicting $\mathrm{H}_{2}$ offgas with feed composition.

The amounts of $\mathrm{NO}_{2}$ and $\mathrm{N}_{2}$ offgas from the quartz melter formated feed test and PSCM-23 were nearly the same (see Figure 6.4) and were higher than the amounts of $\mathrm{NO}_{3}^{-}$and $\mathrm{NO}_{2}^{-}$would predict. The unformated quartz melter feed produced significantly less $\mathrm{NO}_{x}$, with the amount lower than the amounts of nitrogen in the feed. The high sugar test produced large amounts of $\mathrm{N}_{2}(-75 \%)$ in addition to $\mathrm{NO}_{x}$. No large-scale test data were available for comparison for feeds containing large amounts of sugar.

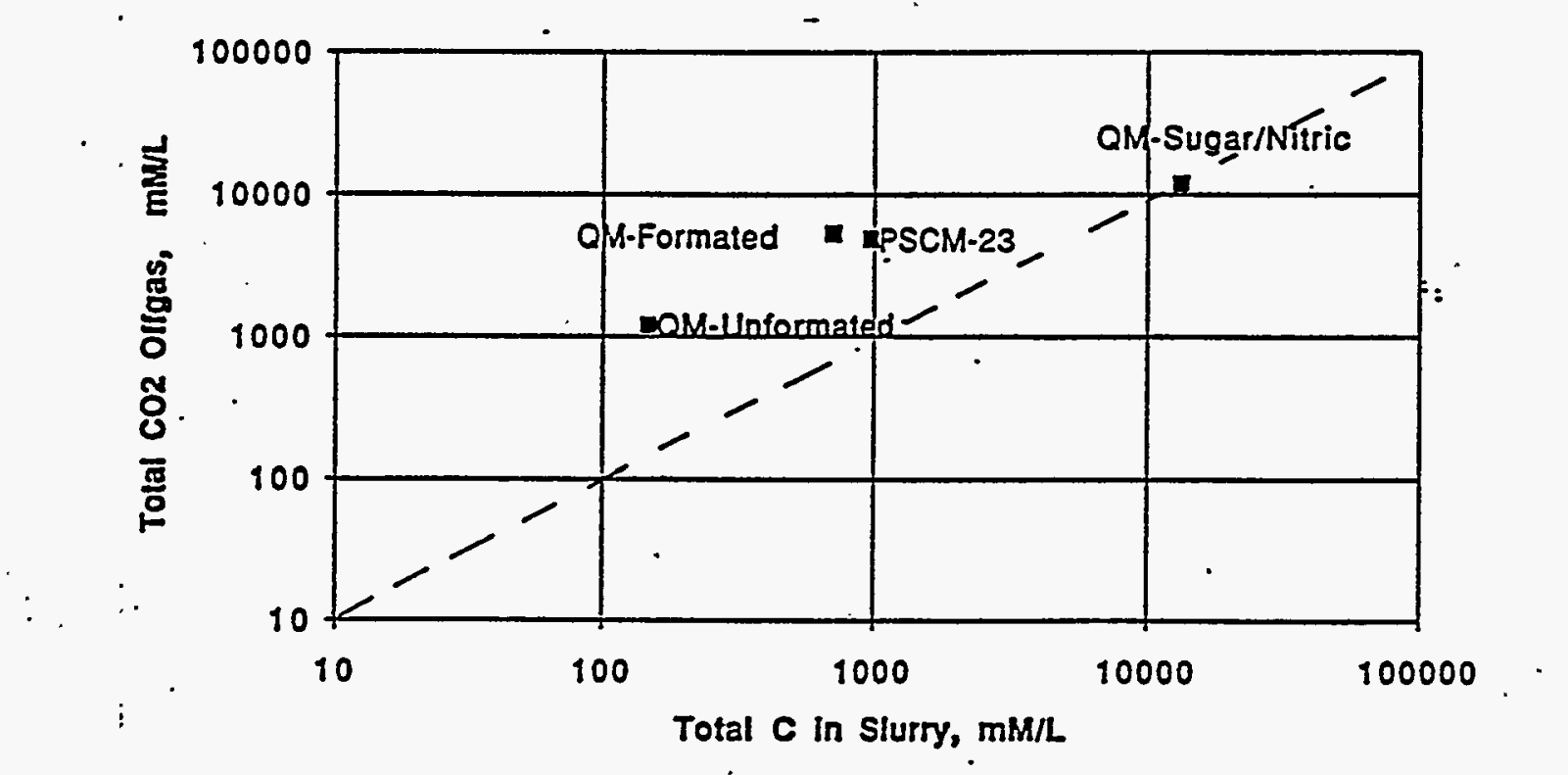

Figure 6.2. Total $\mathrm{CO}_{2}$ Offgas Dependence on Total $\mathrm{C}$ in Feed Comparing Pilot-Scale Tests to Quartz Melter Tests 


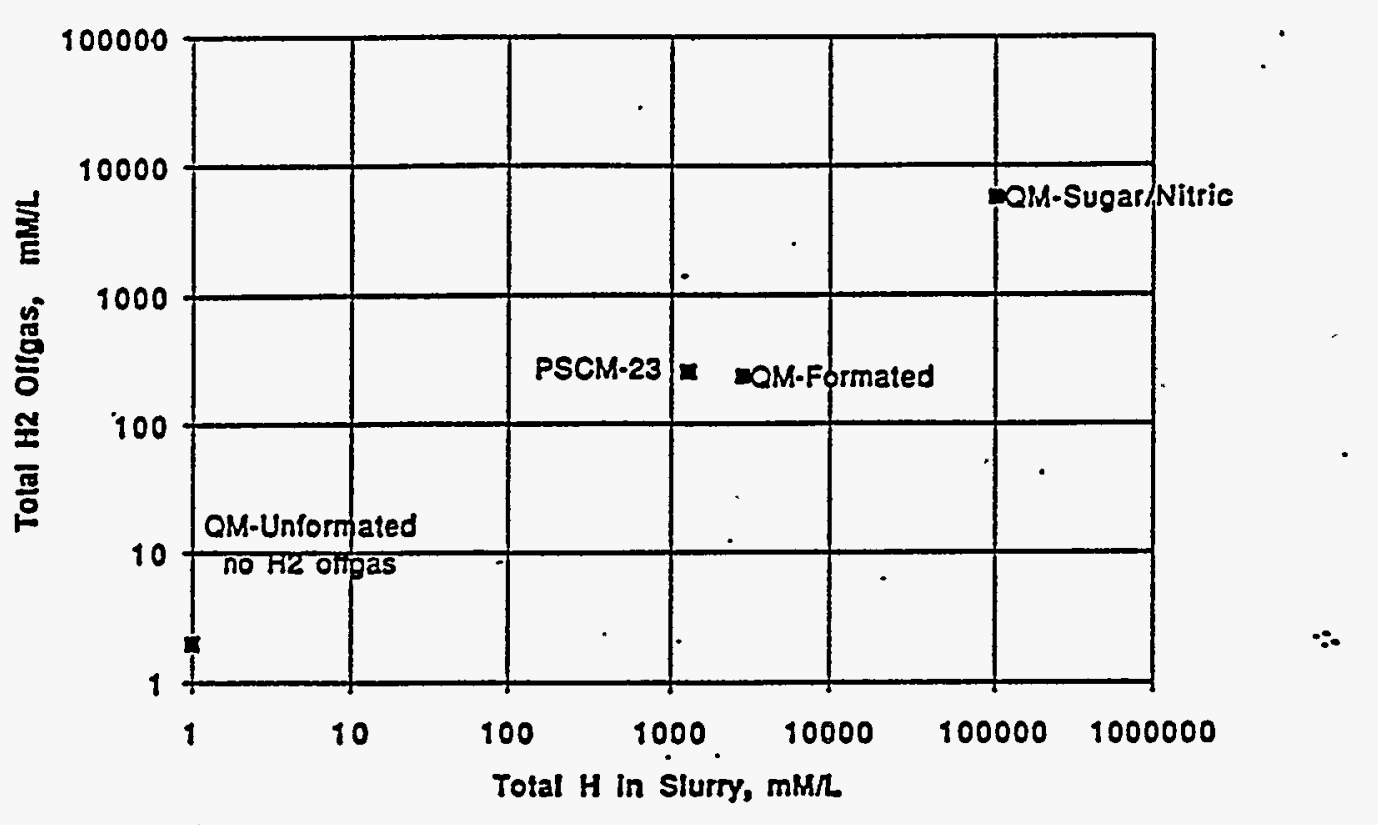

Figure 6.3. Total $\mathrm{H}_{2}$ Offgas Dependence on Total $\mathrm{H}$ in Feed Comparing Pilot-Scale Tests to Quartz Melter Tests

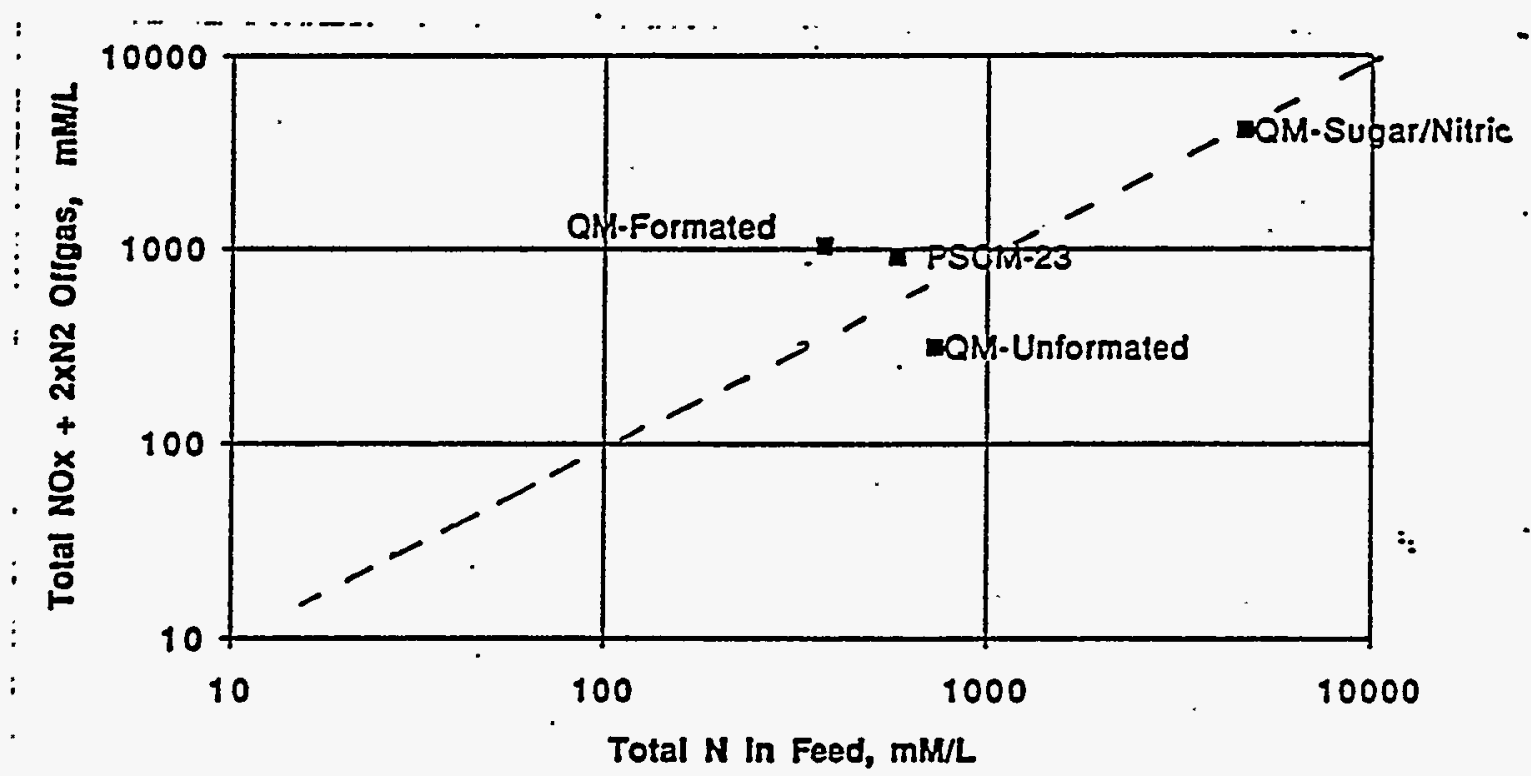

Figure 6.4. Total $\mathrm{NO}_{\mathrm{x}}+2 \mathrm{xN}_{2}$ Offgas Dependence on Total Nitrogen in Feed Comparing Pilot-Scale Tests to Quartz Melter Tests. $\mathrm{NO}_{x}+2 \mathrm{xN}_{2}$ refers to the $\mathrm{y}$ axis scale which was computed by adding the quantity of $\mathrm{NO}_{x}$ detected to the quantity obtained by doubling the $\mathrm{N}_{2}$ quantity. 


\subsection{References}

Abe, O., T. Utsunomiya, and Y. Hoshino. 1983. "The Reaction of Sodium Nitrite with Silica.". Bull. Chem. Soc. Jp̣n. 56(2):428.

Ahn, J. S., and P. Hrma. 1986. "Effect of Heat Pretreatment on Foaming of Simulated Nuclear Waste in a Borosilicate Glass Melt." Advances in Ceramics, Vol. 20. American Ceramic Society, Westerville, Ohio.

Bickford, D. F., and R..B. Diemer. 1986. "Redox Control of Electric Melters with Complex Feed Compositions. I. Analytical Methods and Models." J. Non-Crystalline Solids 84:276-284.

Bickford, D. F., R. B. Diemer, and D. C. Iverson. 1986. "Redox Control of Electric Melters with Complex Feed Compositions. II. Preliminary Limits for Radioactive Waste Melters." J. Non-Crystalline Solids 84:285-291.

Blair, H. J., and J. M. Lukacs. 1980. "Investigation of Foaming During Nuclear Defense-Waste Solidification by Electric Melting." PNL-3552, Pacific Northwest Laboratory, Richland, Washington.

Bowan, B. W. 1990. "A Redox Forecasting Correlation Developed Using a New One-Tenth Area Scale Melter for Vitrifying Simulated High-Level Radioactive Wastes." M.S. Thesis, Alfred University, Alfred, New York.

Cecille, L. and M. Kelm. 1986. "Chemical Reactions Involved in the Denitration Process with HCOOH and HCHO." Denitration of Radioactive Liquid hastes, Graham and Trotman, Great Britain, pp. 17-37. •

Chun, K. S. 1977. "Studies on the Thermal Decomposition of Nitrates Found in Highly Active Waste and of Chemicals Used to Convert the Waste to Glass." AERE-R8735.

Dickerson, B. E., H. B. Gray, and G. P. Haight, Jr. 1979. Chemical Principles, 3rd Edition. Benjamin/Cummings, Menlo Park, California.

Elliot, M. L., E. V. Morrey, and J. M. Tingey. September 1991. Radioactive Formating, " Vitrification and Product Testing. Status letter report to Westinghouse Hanford Company. PHTD-C91-05.05F, Pacific Northwest Laboratory, Richland, Washington.

Gausman, G. G., L. M. Donohoe, J. J. Kohli, J. M. Jewell, and J. E. Shelby. 1993. "Solubility of Inert Gases in Glasses and Melts." Ceramic Transactions, VI. 29, Advances in Fusion and Processing of Glass, eds. A. K. Varshreya, P. F. Bickford, and P. P. Bihursak, pp. 379-390. American Ceramic Society, Westerville, Ohio.

Goldman, D. S. 1983. "Oxidation Equilibrium of Iron in Borosilicate Glass." J. Am. Ceram Soc 66(3):205-209. 
Goldman, D. S., D. W. Brite, and W. C. Richey. 1986. "Investigation of Foaming in Liquid-Fed Melting of Simulated Nuclear Waste Glass." J. Am. Ceram. Soc. 69(5):413-417.

Goldman, D. S: 1986. "Melt Foaming, Foam Stability and Redox in Nuclear Waste Vitrification." J. Non-Crystalline Solids 84:292-298.

Goldman, D. S., and D. W. Brite. 1986. "Redox Characterization of Simulated Nuclear Waste Glass." J. Am. Ceram. Soc. 69(5):411-413.

Goles, R. W., and R. K. Nakaoka. 1990. "Hanford Waste Vitrification Program Pilot-Scale Ceramic Melter Test 23." PNL-7142, UC-721, Pacific Northwest Laboratory, Richland, Washington.

Handbook of Chemistry and Physics 62nd edition, eds. R. C. Wenst and M. J. Astle. CRC Press, Boca Raton, Florida, 1981.

Hrma, P. 1990. "Meiting of Foaming Batches: Nuclear Waste Glass." Glastechnische Berichte 63K:360-369.

Iwase, M., T. Yamamoto, K. Kawamura, and H. Ohuchi. 1994. "Activities and Solubilities of Ferrous Oxide in Melts Formed During the Immobilization of High Level Nuclear Waste." Gloss Technology 35(2):77-82.

Jain, V. 1993. "Redox Forecasting in the West Valley Vitrification System." Ceramic Transactions, Vbl. 29, Advances in Fusion and Processing of Glass, eds. A. K. Varshneya, D. F. Bickford, and P. P. Bihuniak, pp. 523-533. American Ceramic Society, Westerville, Ohio.

Jones, D. R., W. C. Jansheski, and D. S. Goldman. 1981. "Spectrophotometric Determination of Reduced and Total Iron in Glass with 1, 10-Phenanthroline." Anal. Chem. 53:923-924.

Kim, D. S., and P. Hrma. 1990. "Volume Charges During Batch to Glass Conversion." Ceramic Bulletin 69(6):1039-1043.

Lucktong, C., and P. Hrma. 1988. "Oxygen Evolution During $\mathrm{MnO}-\mathrm{Mn}_{3} \mathrm{O}_{4}$ Dissolution in a Borosilicate Melt." J. Am. Cer. Soc 71:323.

Mysen, B. O., F. Siefert, and D. Virgo. 1980. "Structure and Redox Equilibria of Iron-Bearing Silicate Melts." American Mineralogist 65:867-884.

Parker, C. A., G. G. Gausman, and J. E. Shelby. 1993. "Carbon Dioxide Solubility in Alkali Borate Melts." Ceramic Transactions Advances in Fusion and Processing of Glass, eds. A. K. Varshreya, P. F. Bickford, and P. P. Bihuniak, pp. 391-396. American Ceramic Society, Westerville, Ohio.

Paul, A. 1982. Chemistry of Glasses, 2nd Edition. Chapman and Hall, New York, New York. 
Ramsey, W. G., C. M. Jantzer and D. F. Bickford. 1991. "Redox Analyses of SRS Melter Feed Slurry; Interactions Between Formate, Nitrate, and Phenol Based Dopants." Ceramic Transactions, Vil. 23, Nuclear Whste Management IV, eds. G. G. Wicks, D. F. Bickford, and L. R. BunnelI, pp. 259-265. American Ceramic Society, Westerville, Ohio.

Ramsey, W. G., T. D. Taylor, K. D. Wiemers, C. M. Jantzen, N. D. Hutson, and D. F. Bickford. 1993. "Effects of Formate and Nitrate Content on Savannah River and Hanford Waste Glass Redox." Ceramic Transactions, Vol. 29, Advances in Fusion and Processing of Glass, eds. A. K. Varshneya, D. F. Bickford, and P. P. Bihuniak, pp. 535-544. American Ceramic Society, Westerville, Ohio.

Ryan, J. L. 1994. "Redox Reactions and Foamings in Nuclear Waste Glass Melting." Pacific Northwest Laboratory, PVTD-C94-03.026.

Schreiber, H. D., G. B. Balazs, B. E. Carpenter, J. E. Kirkley; L. M. Minnix, and P. L. Jamison. 1984. "An Electromotive Force Series in a Borosilicate Glass-Forming Melt." Communications of the American Ceramic Society, pp. C106-109. American Chemical Society, Westerville, Ohio.

Schreiber, H. D., and A. L. Hockman. 1987. "Redox Chemistry in Candidate Glasses for Nuclear Waste Immobilization." J. Am. Ceram. Soc. 70(8):591-594.

Schreiber, H. D., C. W. Schreiber, M. W. Riethmiller, and J. Sloan Dowrey. 1990. "The Effect of Temperature on the Redox Constraints for the Processing of High-Level Nuclear Waste Glass into a Glass Waste Form." Mat. Res. Soc. Proc. Vol. 176:419-26.

Schreiber, H: D., B. K. Kochanowski, and C. W. Schreiber. 1994. "Compositional Effects on the Iron Redox State in Model Glasses for Nuclear Waste Immobilization." Ceramic Transacrions, Vol. 39, Environmental and Whste Management Issues in the Ceramic Industry, ed. G. B. Mellinger, pp. 141-150. American Ceramic Society, Westerville, Ohio.

Smith, H. D., K. D. Wiemers, M. H. Langowski, M. R. Powell, and D. E. Larson. 1993. Evaluation of HWVP Feed Preparation Chemistry for an NCAW Simulant-Fiscal Year 1993: Evaluation of Offgas Generation and Ammonia Formation. Pacific Northwest Laboratory, PHTD-C93-03.02.

Vienna, J. D., P. A. Smith, and P. R. Hrma. "The Role of Frit in Nuclear Waste Vitrification." Ceramic Transactions (in press). 
Appendix A

GC-MS Data 


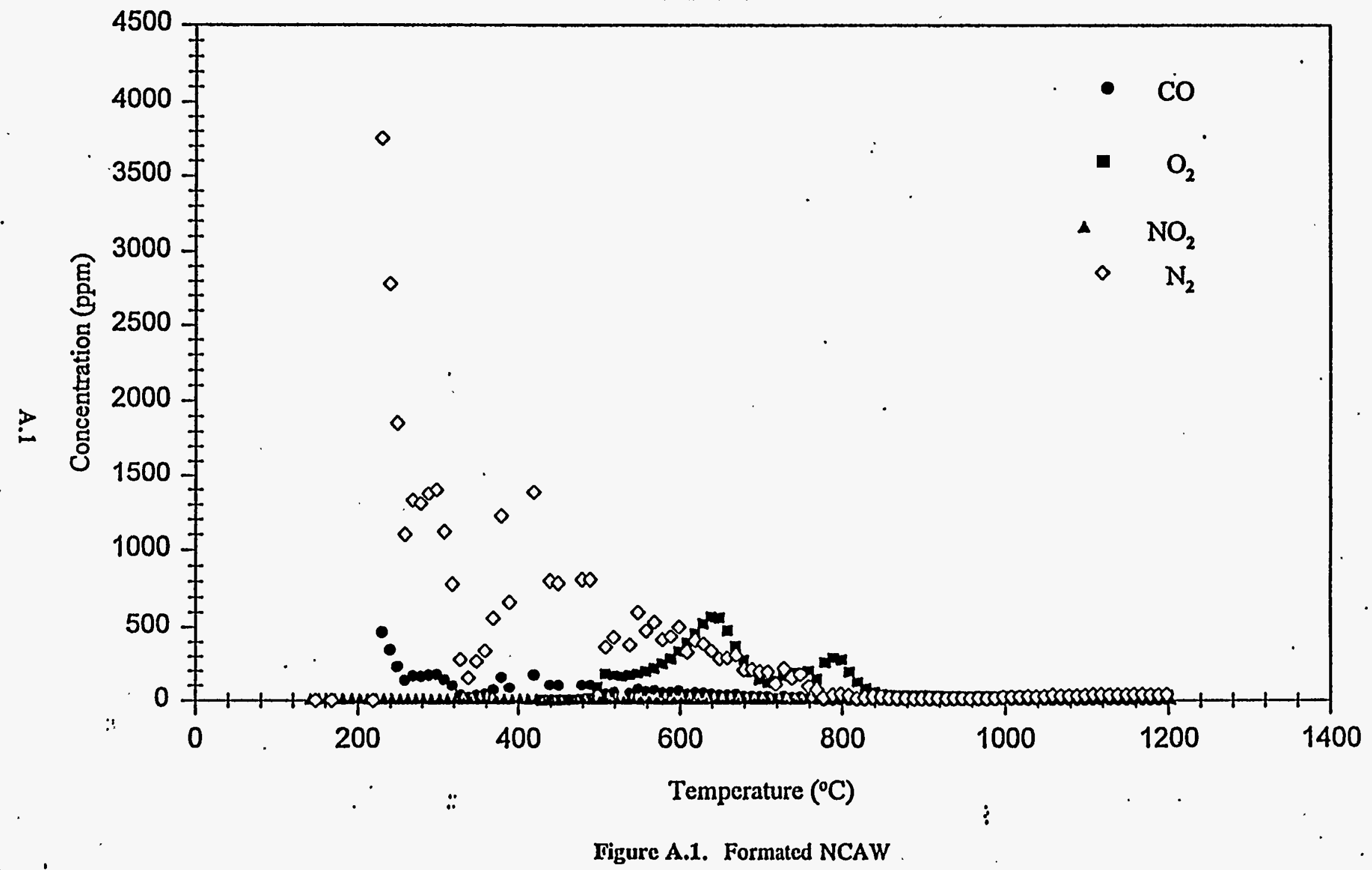




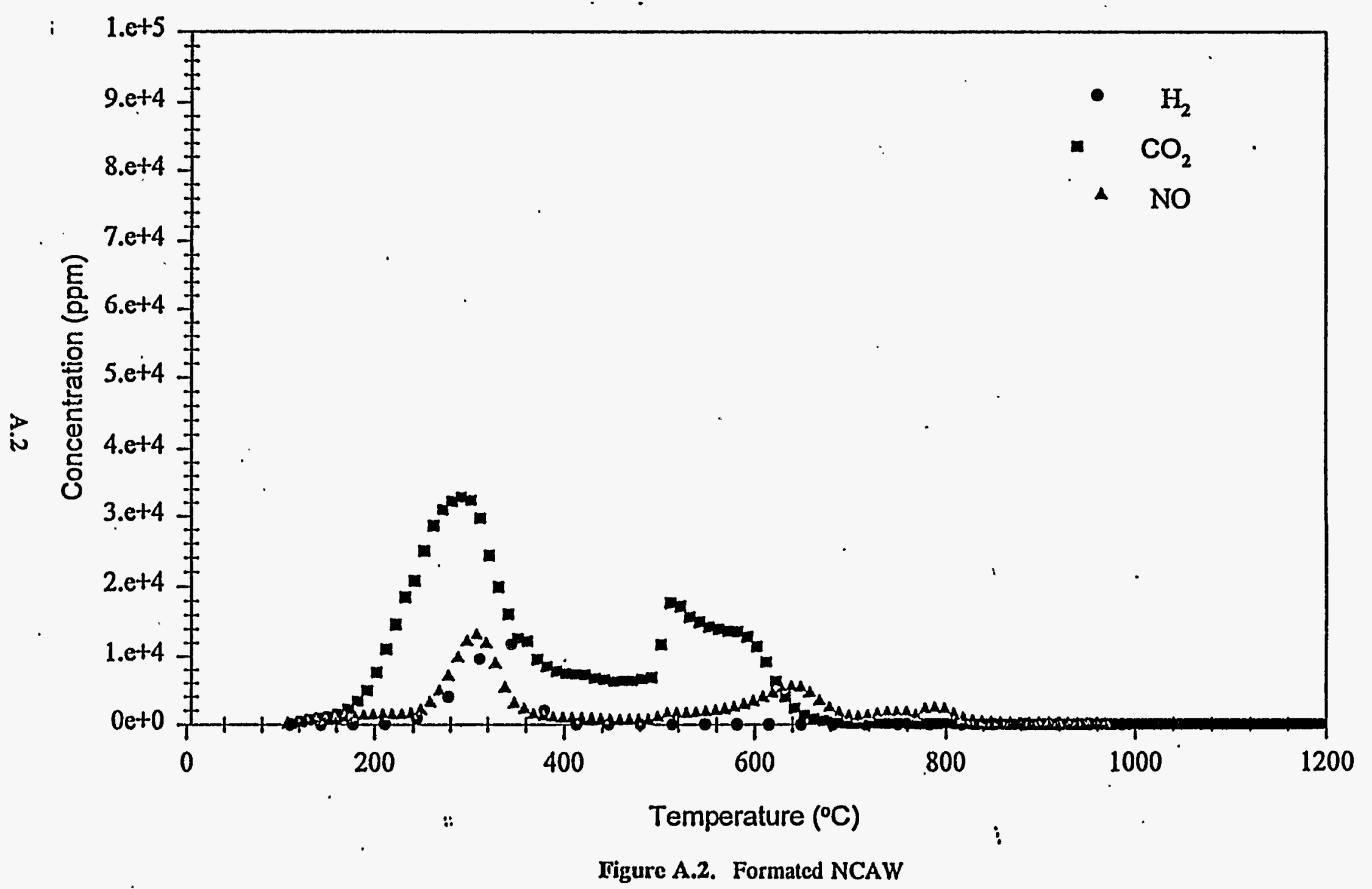




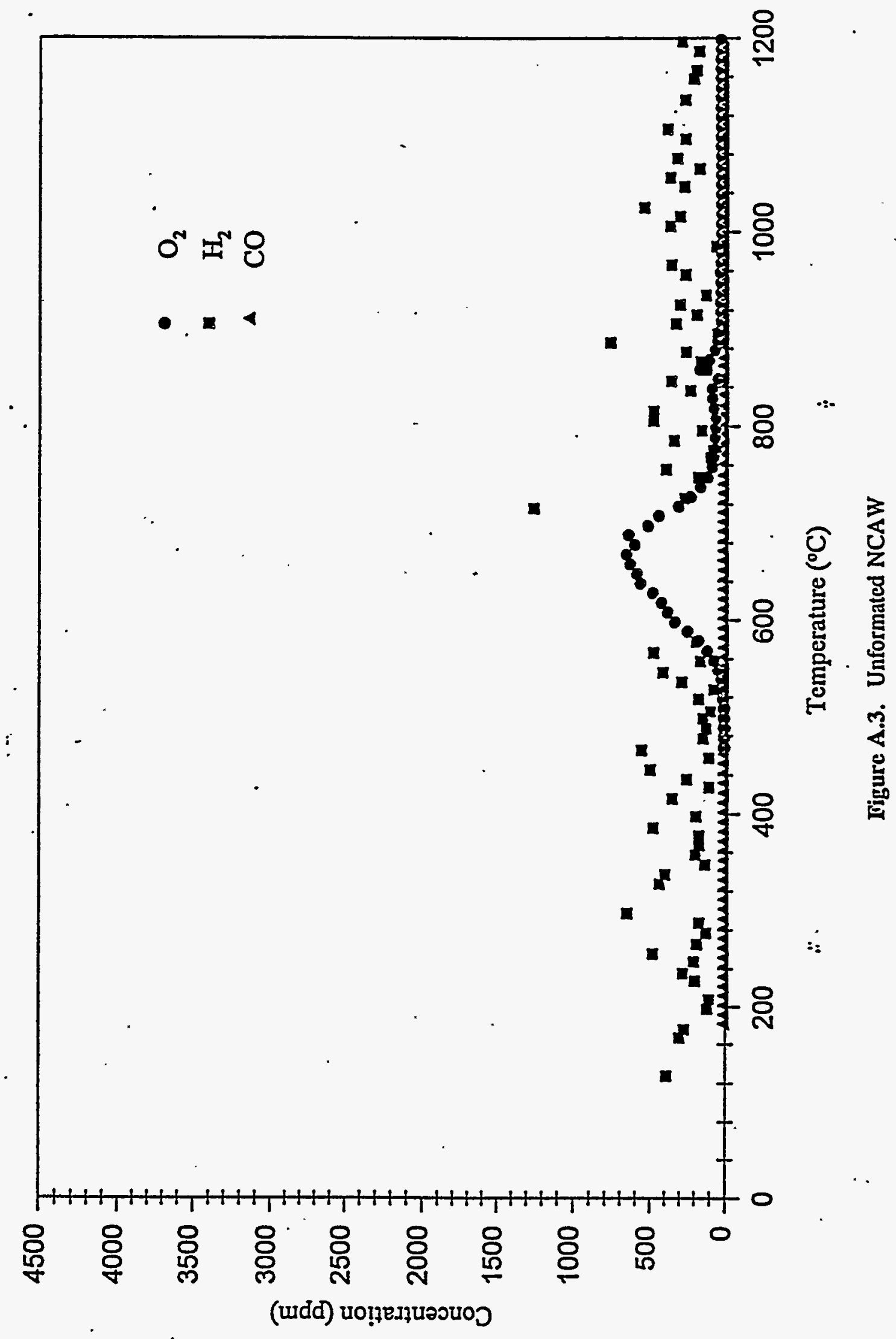




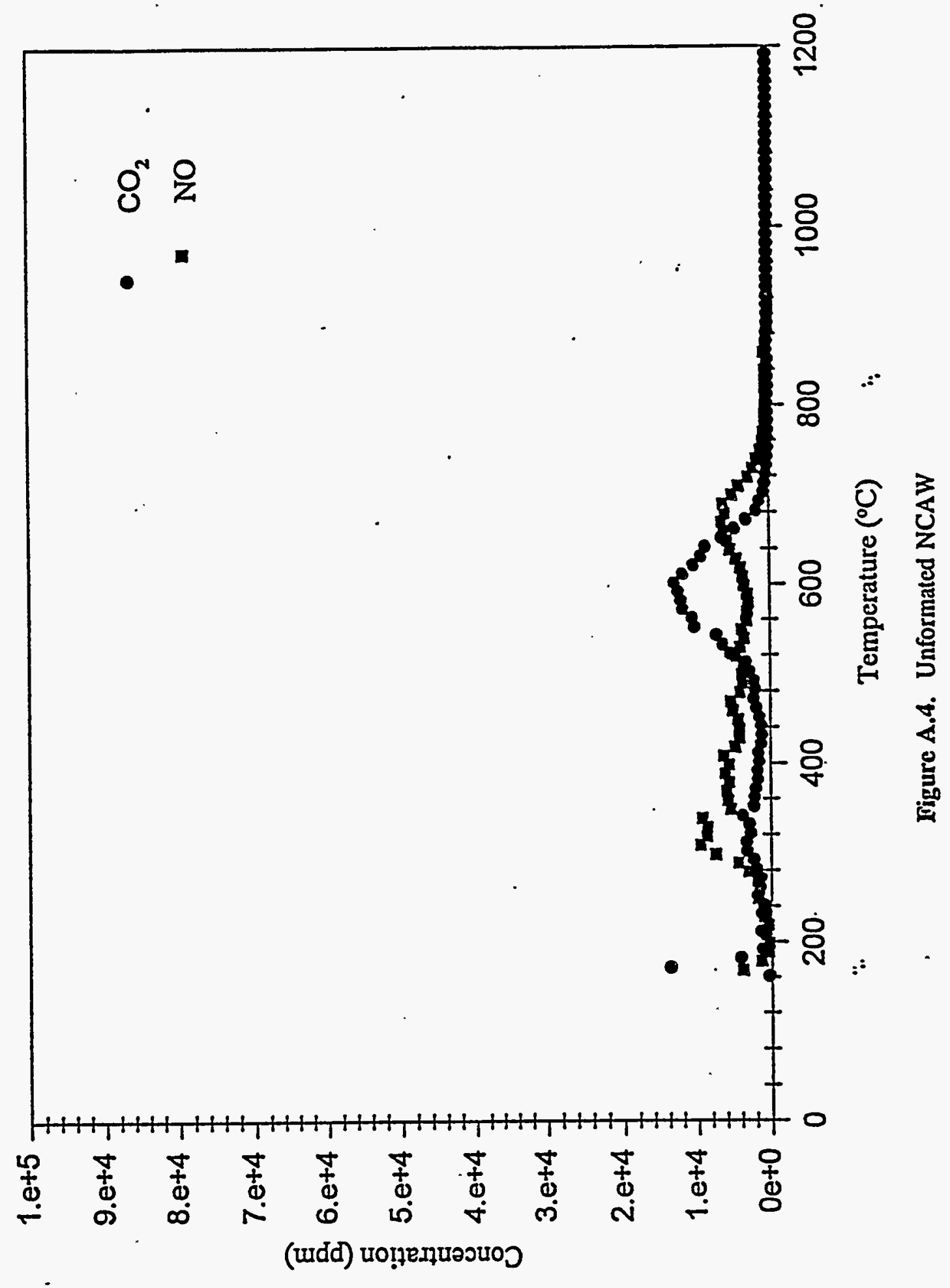

A. 4 


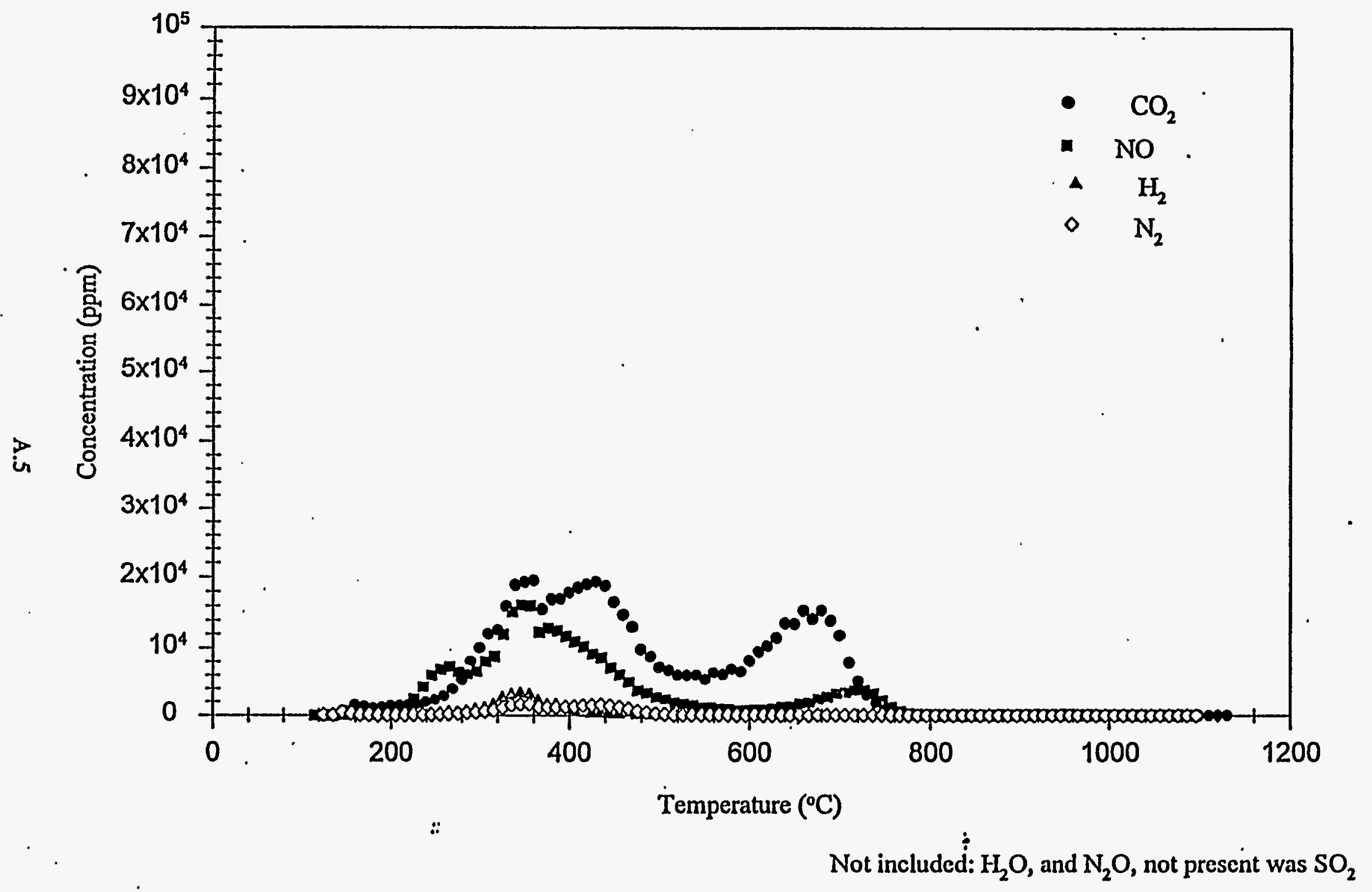

Figure A.5. Nitric Acid Sample pH $\sim 4$ 


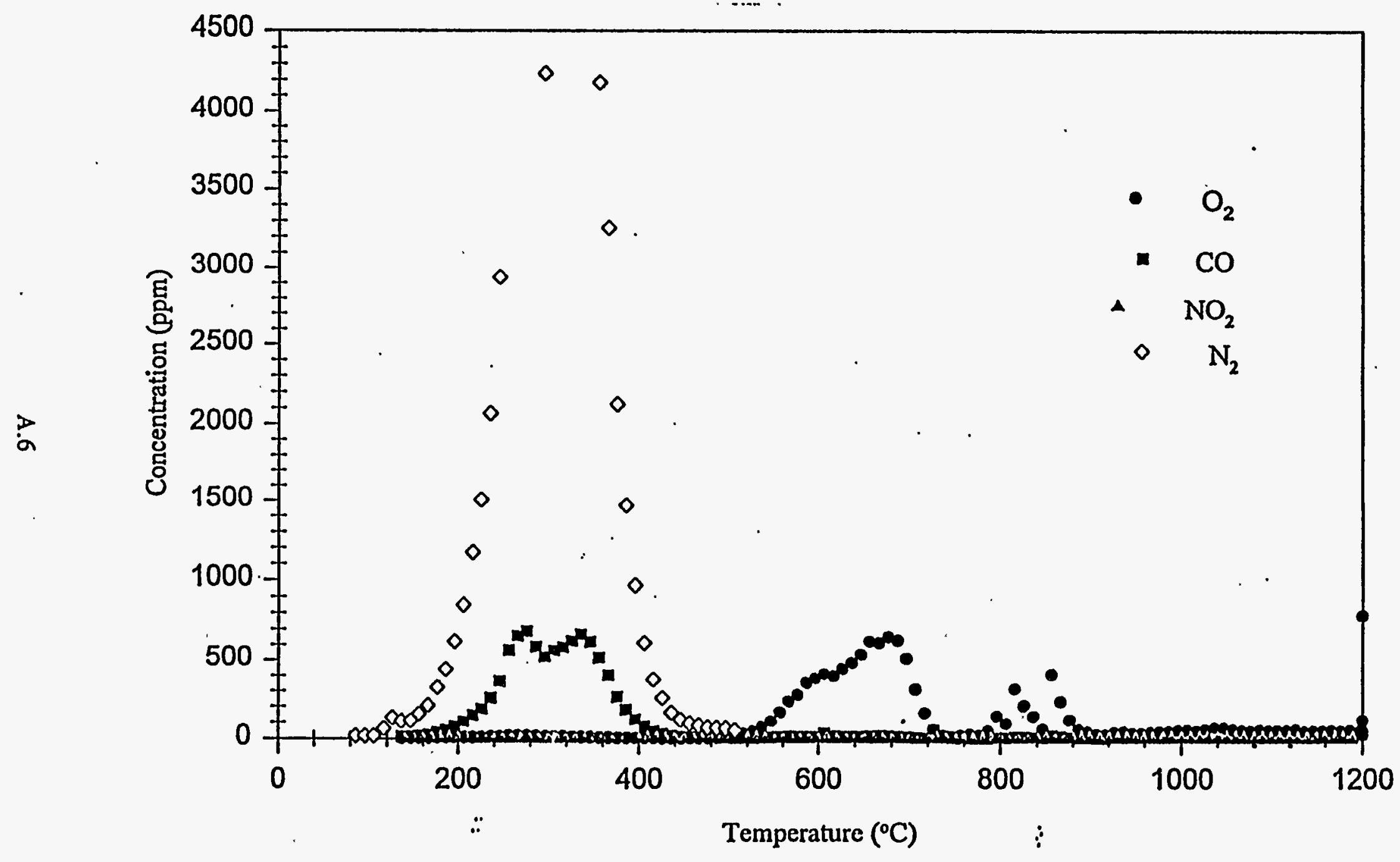

Figure A.6. Nitric Acid Sample pH $\sim 4$ (4x wcight) 


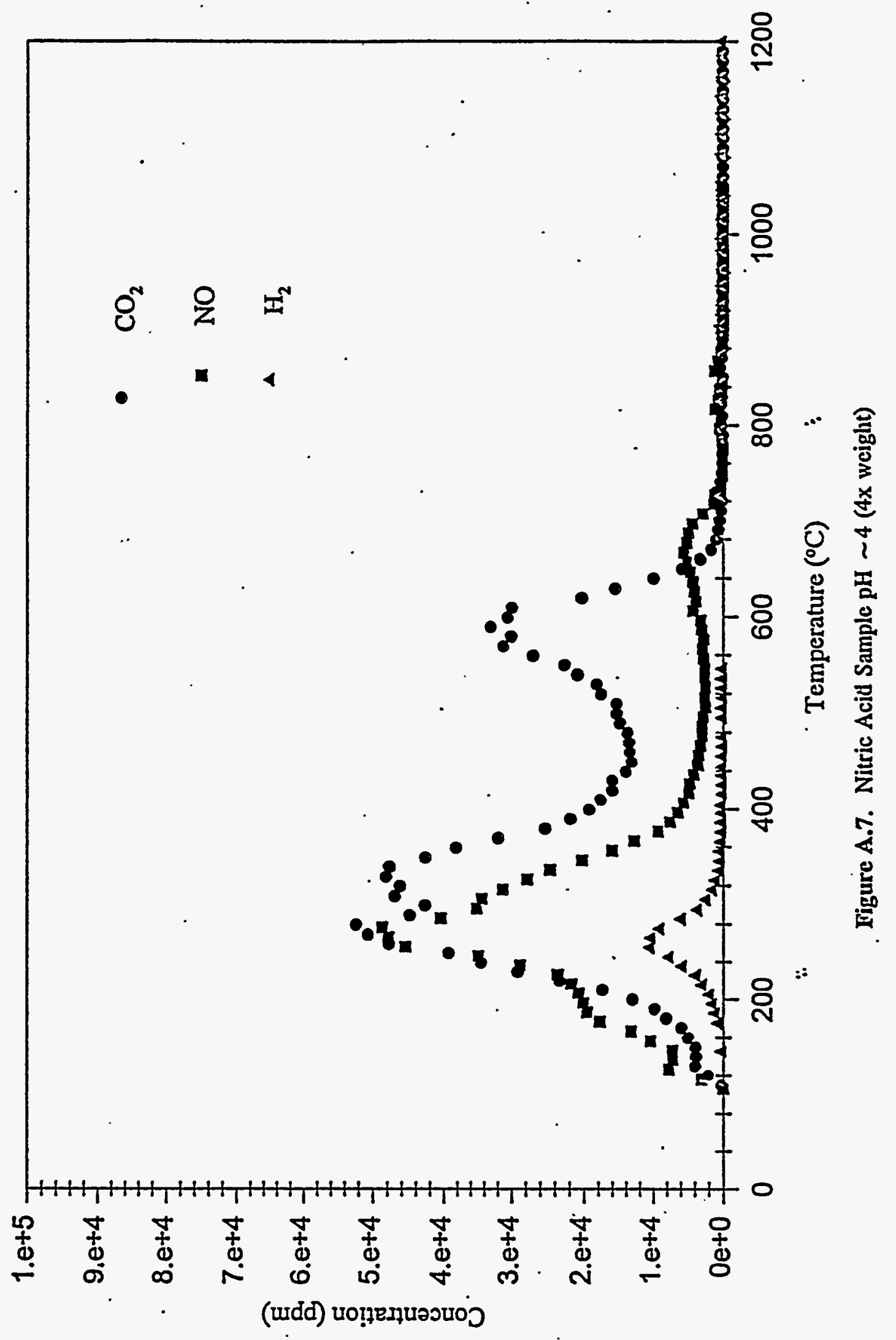




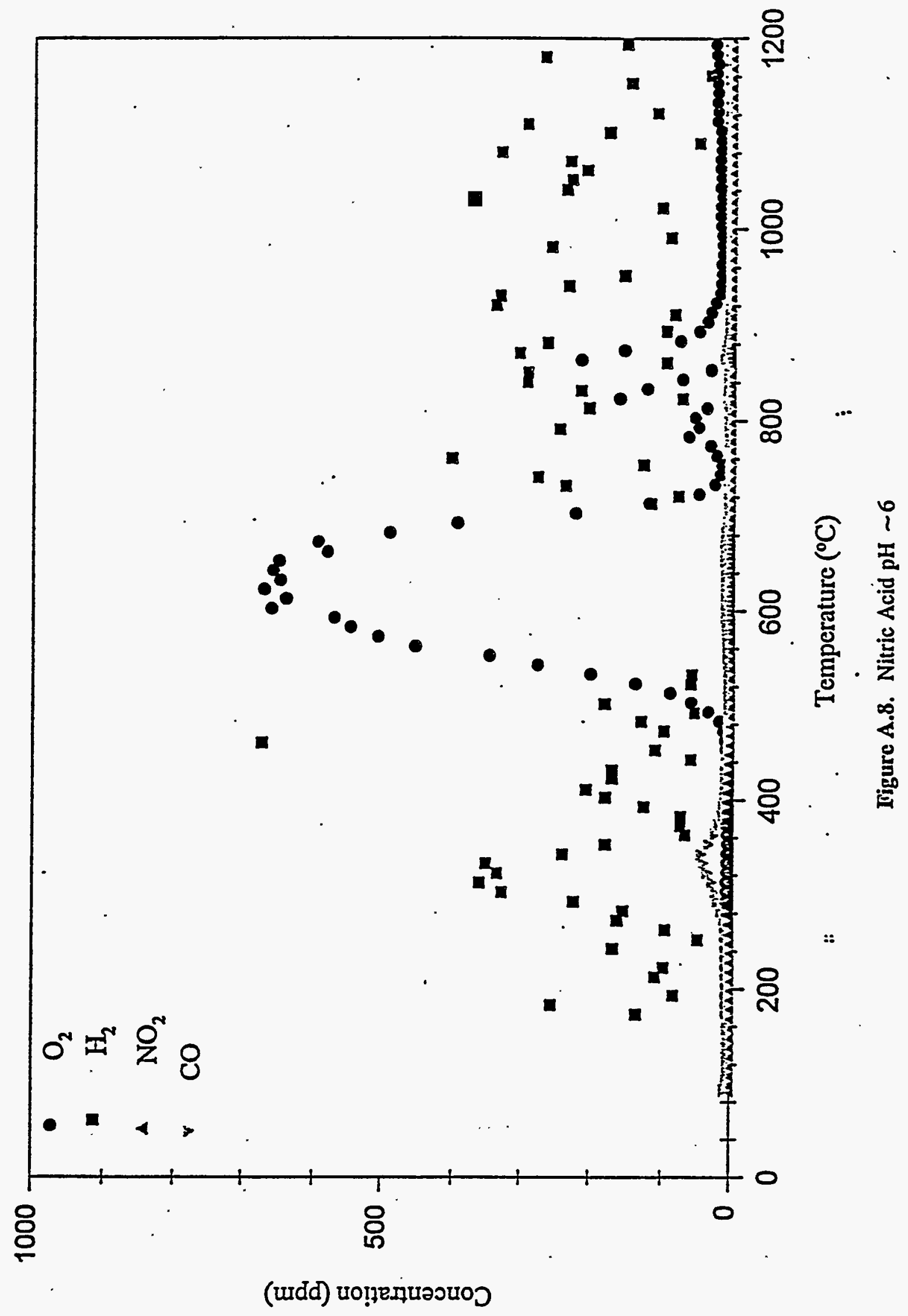

A. 8 


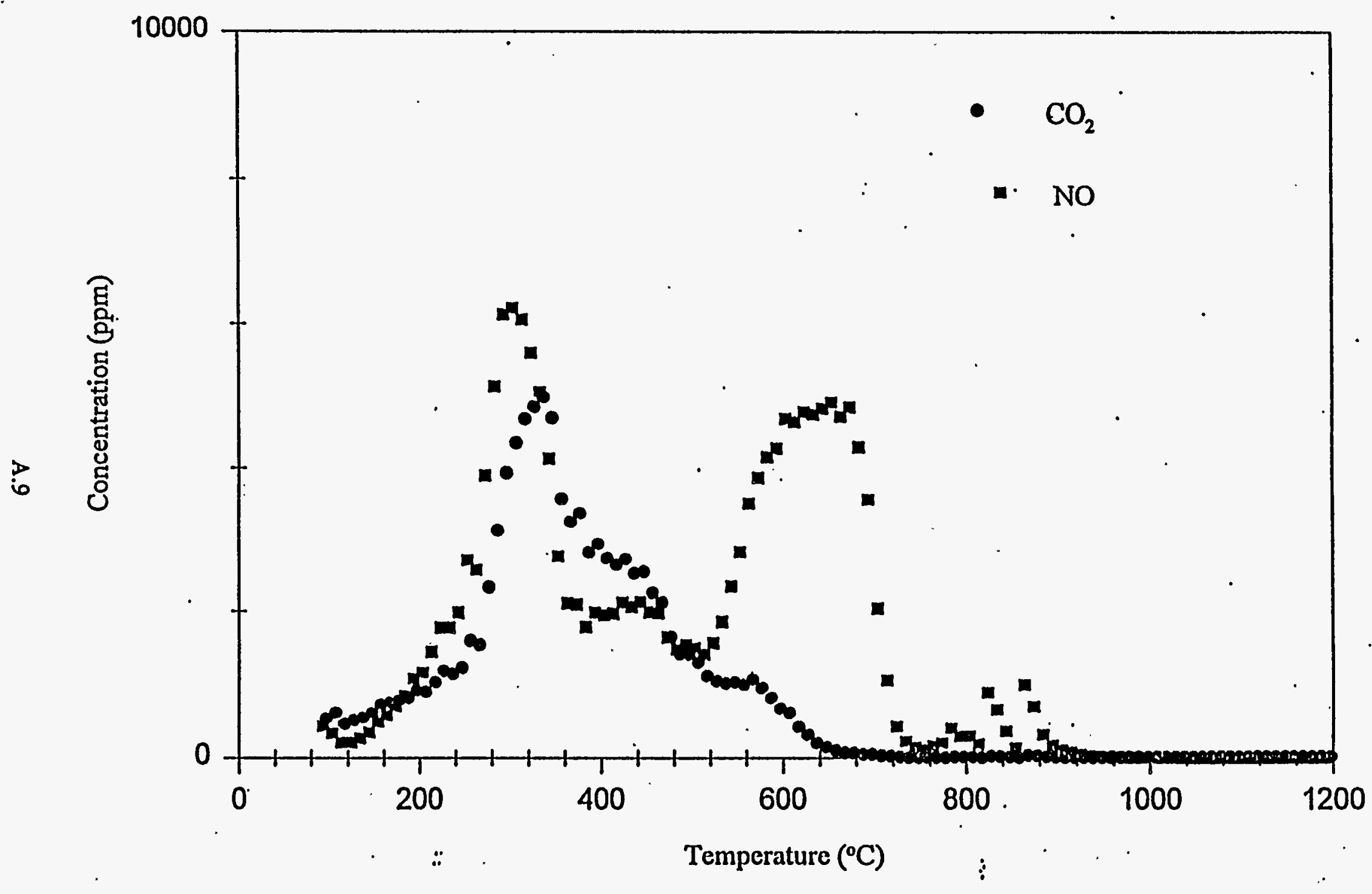

Figurc A.9. Nitric Acid pH $\sim 6$ 


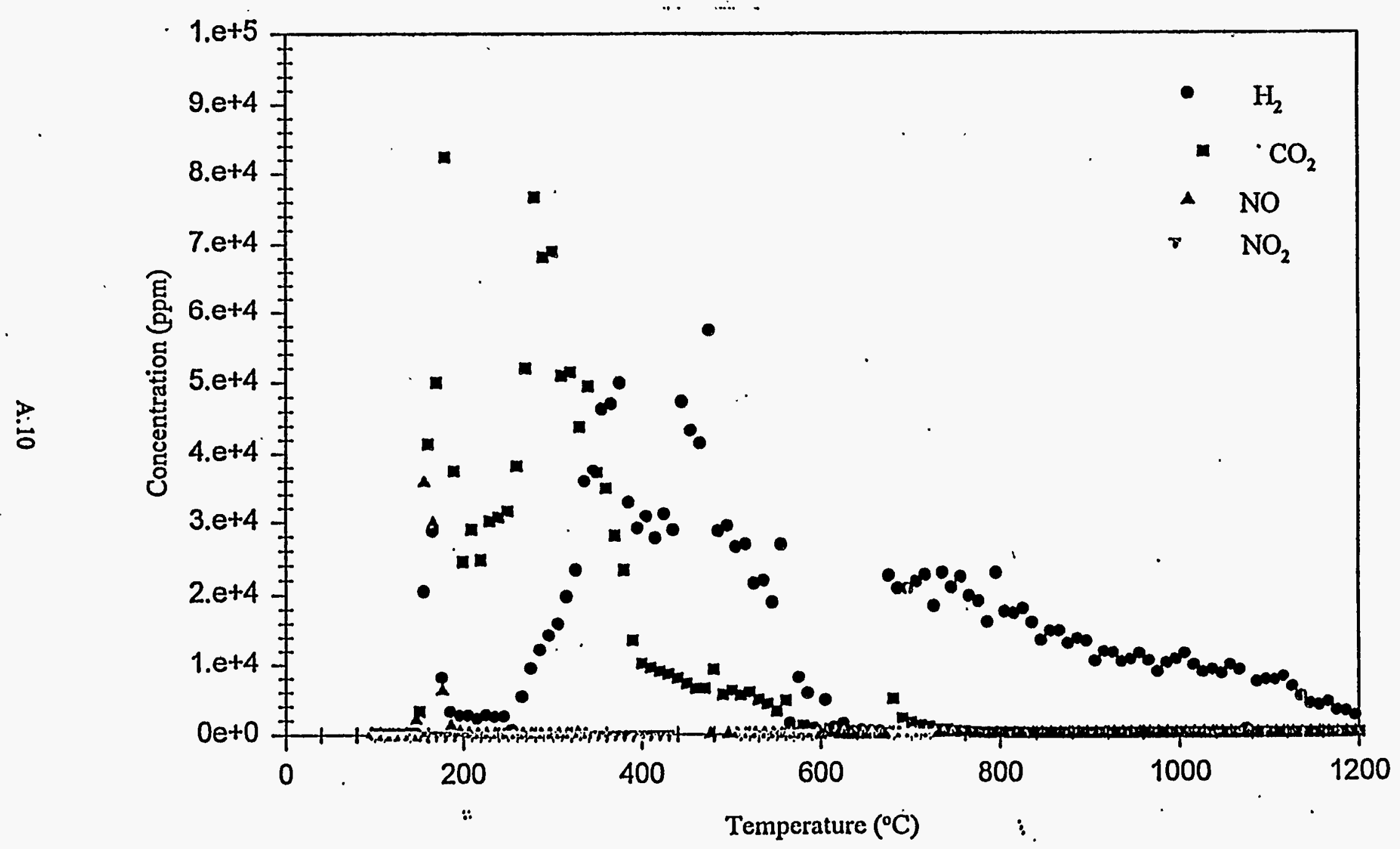

Figure A.10. Sugar in NCAW Fecd $\left(\mathrm{pH} \sim 6 \mathrm{w} / \mathrm{HNO}_{3}\right)$ 


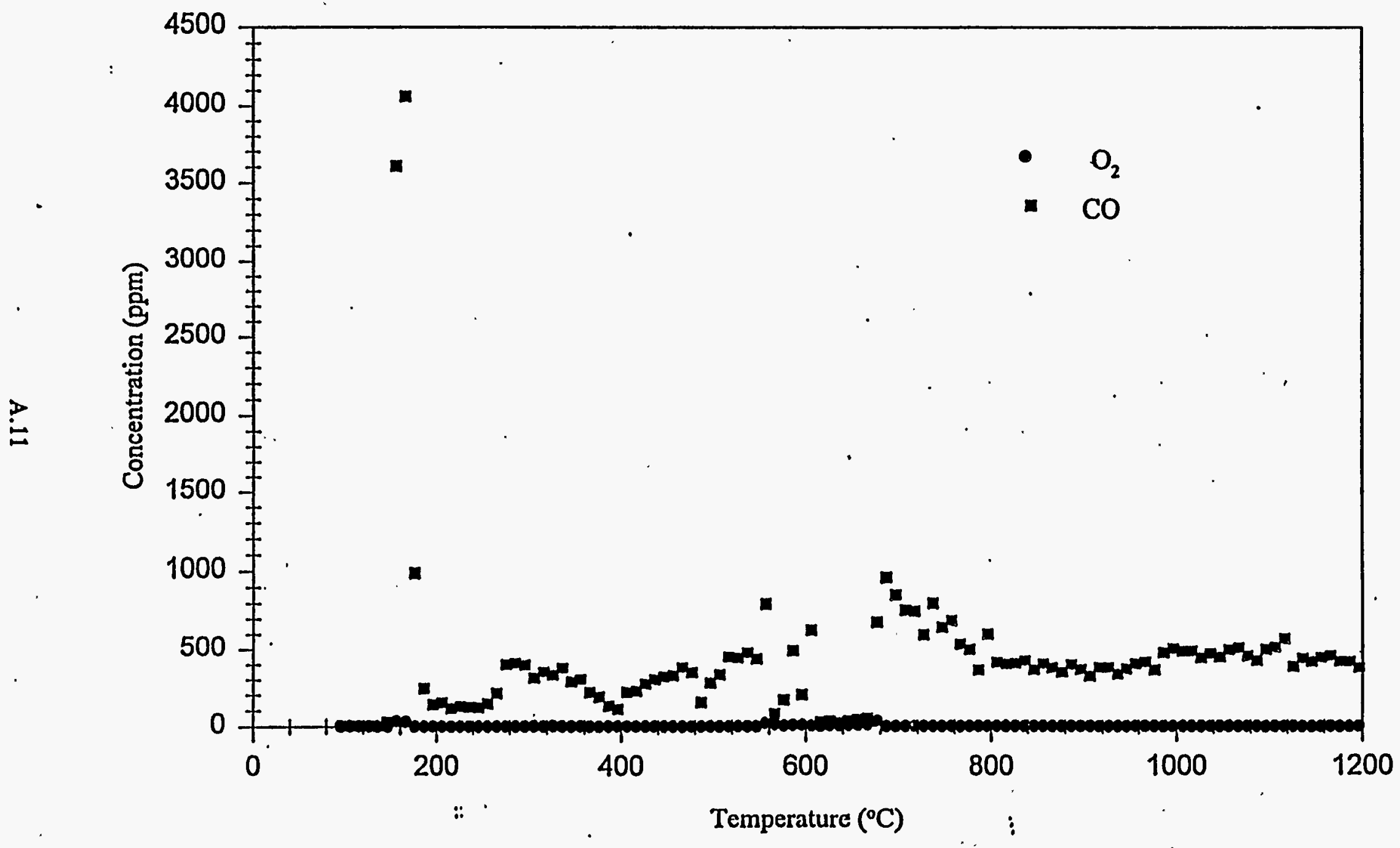

Tigure A.11. Sugar in NCAW Feed (pH $\left.\sim 6 \mathrm{w} / \mathrm{HNO}_{3}\right)$. 


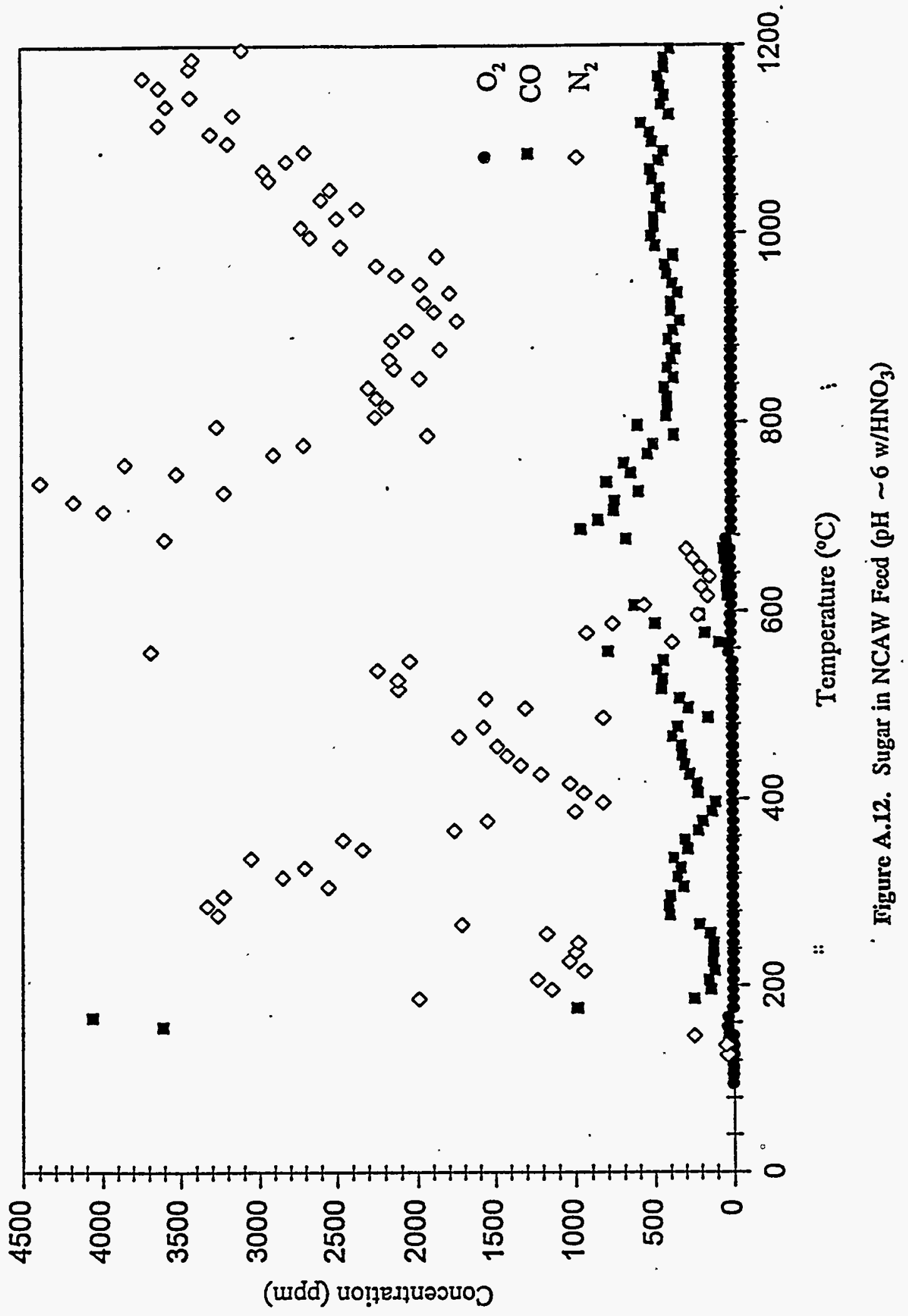


Appendix B

Some Decomposition Temperatures

(Chun, 1979 and CRC Handbook) 


\section{Appendix B}

\section{Some Decomposition Temperatures}

(Chun, 1979 and CRC Handbook)

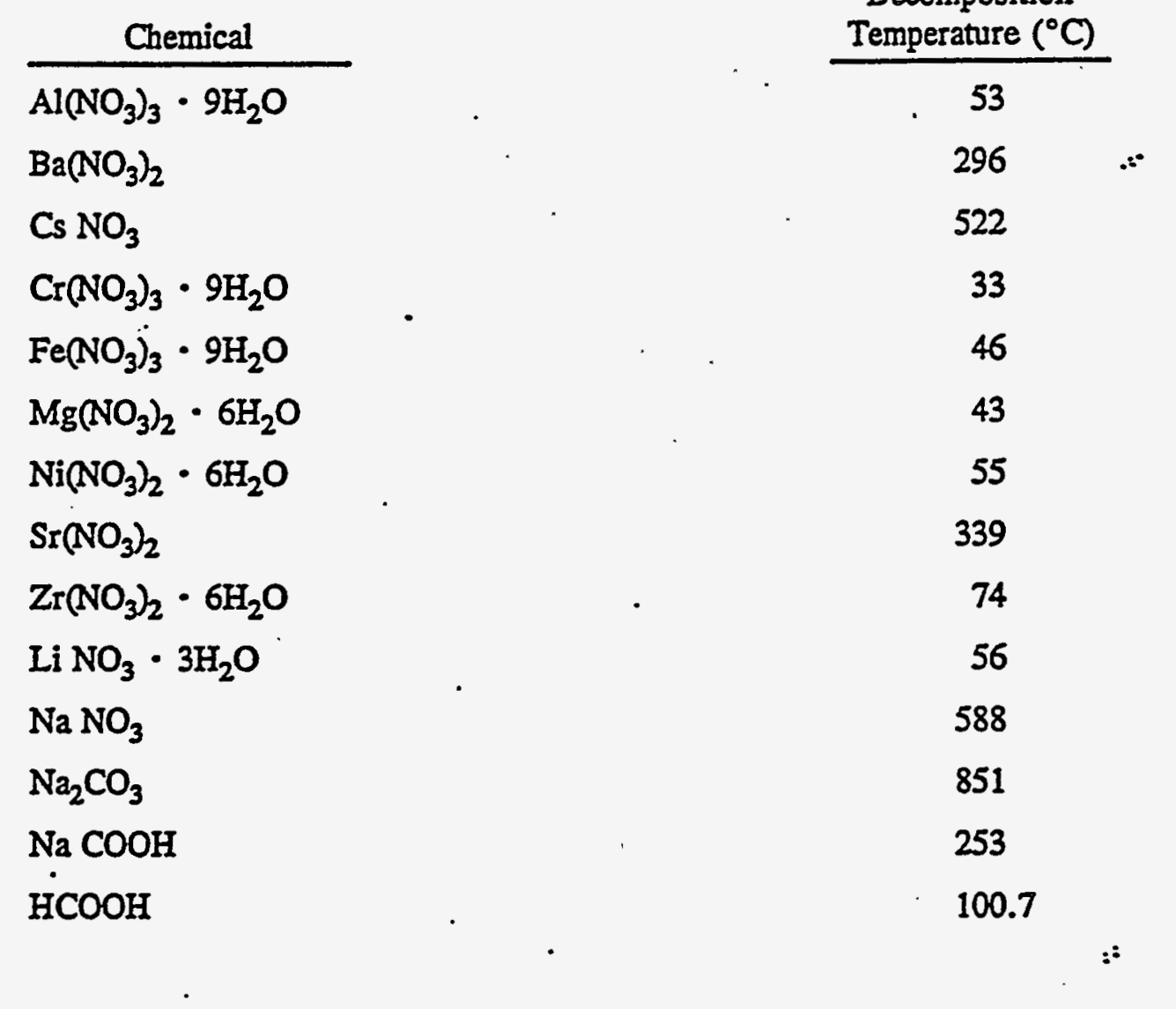

